\title{
Chromosomal abnormalities in hematological malignancies
}

Citation for published version (APA):

Schouten, H. C. (1991). Chromosomal abnormalities in hematological malignancies. [Doctoral Thesis, Maastricht University]. Maastricht University. https://doi.org/10.26481/dis.19910207hs

Document status and date:

Published: 01/01/1991

DOI:

10.26481/dis.19910207hs

Document Version:

Publisher's PDF, also known as Version of record

\section{Please check the document version of this publication:}

- A submitted manuscript is the version of the article upon submission and before peer-review. There can be important differences between the submitted version and the official published version of record.

People interested in the research are advised to contact the author for the final version of the publication, or visit the DOI to the publisher's website.

- The final author version and the galley proof are versions of the publication after peer review.

- The final published version features the final layout of the paper including the volume, issue and page numbers.

Link to publication

\footnotetext{
General rights rights.

- You may freely distribute the URL identifying the publication in the public portal. please follow below link for the End User Agreement:

www.umlib.nl/taverne-license

Take down policy

If you believe that this document breaches copyright please contact us at:

repository@maastrichtuniversity.nl

providing details and we will investigate your claim.
}

Copyright and moral rights for the publications made accessible in the public portal are retained by the authors and/or other copyright owners and it is a condition of accessing publications that users recognise and abide by the legal requirements associated with these

- Users may download and print one copy of any publication from the public portal for the purpose of private study or research.

- You may not further distribute the material or use it for any profit-making activity or commercial gain

If the publication is distributed under the terms of Article $25 \mathrm{fa}$ of the Dutch Copyright Act, indicated by the "Taverne" license above, 


\section{Chromosomal abnormalities in hematological malignancies}




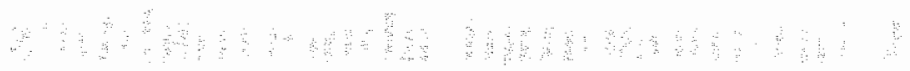

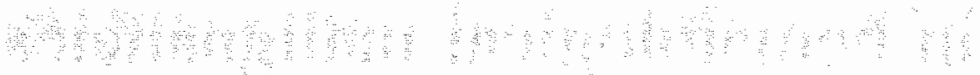




\title{
Chromosomal abnormalities in hematological malignancies
}

PROEFSCHRIFT

\author{
ter verkrijging van de graad van doctor \\ aan de Rijksuniversiteit Limburg te Maastricht, \\ op gezag van de Rector Magnificus, Prof. mr. M.J. Cohen, \\ volgens het besluit van het College van Dekanen, \\ in het openbaar te verdedigen \\ op donderdag, 7 februari 1991 om 16.00 uur
}

door

Hendricus Constantinus Schouten 


\section{Promotores}

Prof. dr. G.H. Blijham

Prof. dr. J.O. Amitage, University of Nebraska, Omaha, NE, USA

\section{Beoordelingscommissie}

Prof. dr. J.P.M. Geraedts

Prof. dr. J.W. Arends

Prof. dr. B. Löwenberg, Erasmusuniversiteit Rotterdam

Prof. dr. P.J.C. van Breda Vriesman

Dr. D.J. van Rhenen

KONINKLIJKE BIBLIOTHEEK, DEN HAAG

Schouten, Hendricus Constatinus

Chromosomal abnormalities in henatological malignancies /

Hendricus Constatinus Schouten. - Maastricht : Datawyse.

- III.

Thesis Maastricht. - With ref.

ISBN 90-5291-044-8

SISO 573.2 UDC $576.3: 616.15(043.3)$

Subject headings: lymphoma / chromosomal abnormalities / leukemia.

Het in dit proefschrift gepresenteerde onderzoek werd in belangrijke mate mogelijk gemaakt door de Nederlandse Kankerbestrijding. Verder dient de ondersteuning door Boehringer Mannheim Nederland BV, Bristol-Myers Squibb BV, DG Lederle Nederland, Glaxo BV en Lundbeck BV vermeld te worden. 
voor vier dames en éen heer 


\section{Contents}

CHAPTER $1 \ldots \ldots \ldots \ldots \ldots \ldots \ldots \ldots \ldots \ldots$

Cancer cytogenetics: An introduction

CHAPTER $2 \ldots \ldots \ldots \ldots \ldots \ldots \ldots \ldots \ldots \ldots \ldots$

Chromosomal abnormalities in Hodgkin's disease

Blood 1989, 73: 2149-2154

CHAPTER 3

Chromosomal abnormalities in untreated patients with non-

Hodgkin's lymphoma: associations with histology, clinical characteristics and treatment outcome

Blood 1990, 75: 1841-1847

CHAPTER 4

Abnormalities involving chromosome 6 in newly diagnosed patients with non-Hodgkin's lymphoma

Cancer Genetics and Cytogenetics 1990, 47: 73-82

CHAPTER 5

Chromosomal abnormalities in patients with non-cutaneous T-cell non-Hodgkin's lymphoma

European Journal of Cancer 1990, 26: 618-622

CHAPTER 6

The prognostic significance of chromosomal abnormalities in patients with acute myeloid leukemia in a study comparing the efficacy of autologous and allogeneic bone marrow transplantation

Submitted

CHAPTER

Epilogue 


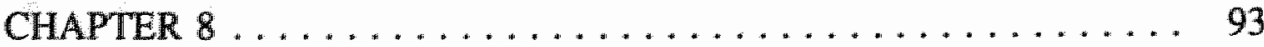

Summary

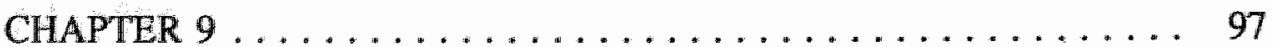

Samenvatting

DANKWOORD . . . . . . . . . . . . . . . . . . . . 101

CURRICULUM VITAE . . . . . . . . . . . . . . . . . . 103 
CHAPTER 1

Cancer cytogenetics:

An introduction 


\section{Y. Introduction}

Although it was not possible to determine the exact number of chromosomes in human beings before $1956(1)$, in 1914 already Theodor Boveri (2) postulated that the transition from normal to malignant cell proliferation was caused by chromosomal abnormalities. This hypothesis has been the subject of much debate until 1960 when Nowell and Hungerford (3) described the Philadelphia chromosome [translocation $t(9 ; 22)$ ] in chronic myeloid leukemia. Later, the finding of non-randomness of karyotypic changes in specific solid tumors and leukemias was convincing evidence that chromosomal abnormalities were not merely coincidental $(4,5)$. Improvements of cell culture techniques and also the introduction of chromosome banding techniques (6) did increase the yield of successful chromosomal analyses in human malignancies resulting in a growing number of abnormalities described. This is best illustrated by the increasing volume of the Catalog of Chromosome Aberrations in Cancer (7), that is based on a registry already containing the karyotype data of more than 10.000 individual human neoplasms.

The characteristic of hematologic malignancies like leukemias of being "a disease in suspension" makes the application of culture techniques relatively easy. Therefore, this is an important explanation that a significant part of the knowledge regarding cancer cytogenetics has been derived from this disease. The significance of the chromosomal abnormalities in the acute leukemias and chronic myeloid leukemia led many researchers to explore the cytogenetics of solid tumors. Although several characteristic karyotypic abnormalities in solid tumors have been reported $(7,8)$, again, most knowledge has come from a hematologic tumor known as non-Hodgkin's lymphoma (NHL). Sofar, only $1 \%$ of the published cytogenetic results deal with primary epithelial tumors, which on the other hand represent $80 \%$ of all human cancers $(9,10)$.

\section{Y Biological significance of chromosomal abnormalities}

Three landmarks in the development of our knowledge of cancer genetics can be recognized: the discovery of the Philadelphia chromosome $\left(\mathrm{Ph}^{1}\right)$ in patients with chronic myeloid leukemia (3), the observation of translocations $t(2 ; 8)$, $t(8 ; 14)$ and $t(8 ; 22)$ occurring frequently in patients with Burkitt type NHL (11-14) and the discovery of a deletion of the long arm of chromosome 13 [del(13q)] in patients with retinoblastoma (15). These observations gave further insight in the biologic significance of these chromosomal abnormalities. Several years after the first reports dealing with these abnormalities and after the rapid development 
of the molecular biology, it appeared that these abnormalities occurred on chromosome loci that were not irrelevant for the development of the disease.

After the introduction of banding techniques with their higher resolution, the $\mathrm{Ph}^{1}$ abnormality was found to consist of a translocation that can be described as $t(9 ; 22)(q 34 ; q 11)(16)$. The application of modern techniques from the molecular biology led to the discovery that in this translocation the $c-a b l$ gene (called this way because of the homology of this gene to the Abelson murine leukemia virus oncogene) on chromosome 9 moves to breakpoint $22 q 11-12(17,18)$. Further analysis revealed that the breakpoints on chromosome 22 were clustered in a small region that is now called the "breakpoint cluster region" (bcr) $(17,19)$. The fusion of the bcr-abl genes resulted in a mRNA encoding a $210 \mathrm{~K}$ polypeptide with a tyrosine-kinase activity $(20,21)$, suggesting the importance of this translocation for cell proliferation (see further).

The finding of three different translocations in Burkitt lymphoma $[\mathrm{t}(2 ; 8)$, $\mathrm{t}(8 ; 14)$ and $\mathrm{t}(8 ; 22)]$ all involving chromosome 8 breakpoint $\mathrm{q} 24$ corresponded with the location of a gene $c-m y c$ (after the avian myelocytomatosis virus oncogene) located on $8 \mathrm{q} 24$ (22). The other breakpoints involved $(2 \mathrm{p} 12,22 \mathrm{q} 11$ and $14 \mathrm{q} 32)$ were found to locate the genes for the $\kappa$ and $\lambda$ light chains and immunoglobulin heavy chain respectively (22). The juxtaposition of the immunoglobulin genes that have a high transcriptional activity and the $c-m y c$ gene, results in an overexpression of $c$-myc. There is some evidence that the $c$-myc product makes the cell independent of growth factor control (23). Also, the cmyc product can enable the cell to enter or traverse S-phase from G1-phase (24). These mechanisms result in an increase in proliferative activity of the cells.

In some patients with retinoblastoma (RB) a deletion of a small part of the long arm of chromosome 13 (15) has been observed. This occurs not only in the tumor cells but also in the normal cells and correlates with the two forms of retinoblastoma, the unilateral form in patients without abnormalities in normal cells and the bilateral form occurring in patients with the deletion also in normal cells (25). This observation has supported previous findings that not only the activation of genes (like in Burkitt lymphoma) or the juxtaposition of genes (like in chronic myeloid leukemia) but also the absence of genes can be related to malignant growth. Patients heterozygous for the RB gene are carriers for the disease. Some of these patients, however, acquire the disease and in the tumor cells of these patients both copies of the gene are absent or inactive. This observation suggests that there exist genes (tumor suppressor genes or antioncogenes) that are able to suppress malignant transformation in a recessive fashion. 
O. Oncogenes, tumor suppressor genes and tumor modulating genes

In the previous section three different events have been described occurring in different malignant diseases: the fusion of an oncogene (abl) with another gene (bcr) resulting in an abnormal MRNA, the juxtaposition of an oncogene (cmyc) with an immunoglobulin gene with a high transcriptional activity and the deletion of a gene (RB), all resulting in malignant growth. How do these chromosomal changes relate to the process of abnormal proliferation and differentiation as is characteristic for transformed cells and malignant tissues?

Viral carcinogenesis research has revealed the existence of viral oncogenes that are able to cause malignant tumors in laboratory animals and cellular transformation in vitro. These viral oncogenes appeared to be derived from regulating genes of vertebrates, transferred by retrovirusses (24). Thirty or more distinct oncogenes have now been described (26). Based on their products they are related to the production of signal transducers (protein kinases [e.g. tyrosine and serine/threonine], G-proteins [GTP and GDP binding proteins], phosphatases and other nuclear proteins), growth factors, growth factor receptors and other membrane proteins $(24,26-28)$. The normal counterparts of these oncogenes are called proto-oncogenes or cellular oncogenes and the chromosome locations of most of these proto-oncogenes have now been described. The locations of several of these genes correlate with chromosome breakpoints that have been observed in malignant cells of patients (29). As can be derived from the function of products of these genes, they act as dominant genes.

The normal cell proliferation is the result of inhibitory and stimulatory influences by growth factors. These growth factors bind to surface growth factor receptors that are able to give a signal mediated by protein kinases, G-proteins and phosphatases to the nucleic structures $(24,28)$. As described before, exactly these mediators are regulated by proto-oncogenes. These proto-oncogenes and their products have, thus, important functions for cell proliferation and possibly differentiation. Therefore, it is not difficult to understand how the introduction of a chromosomal abnormality in the normal cell can result in an altered structure and function of the proto-oncogene and so, indeed, can alter the normal proliferation and differentiation of a cell towards uncontrolled growth, resulting in a malignant tumor.

Also by a variety of chromosome alterations the function of tumor suppressor genes can be changed, thereby allowing the uncontrolled proliferation of tumor cells. In the view of some (30) tumor suppressor genes even play a key role in cancer protection. Extensive research resulted in the cloning of the RB gene (31). After the introduction into a retinoblastoma cell line this $4.7 \mathrm{~kb} \mathrm{cDNA}$ was able to regulate growth and to lead to loss of tumor forming ability (32). Further analysis resulted in the hypotheses that a function of these genes or their 
products could be the regulation of DNA repair $(30,33)$, the induction of differentiation $(34,35)$ and senescence $(30)$, the control of cell proliferation $(30,36)$ and angiogenesis (37). Some preliminary evidence suggests that one interferon gene (alpha) acts as tumor (leukemia) suppressor gene (38).

In addition, a third group of genes, less well defined, can be discriminated. These are involved in oncogenesis and tumor growth without directly affecting cellular proliferation. These genes are called modulating genes. They may be of importance in the regulation of the interaction between tumor cells and the host, like immune responses, metabolism of carcinogens and resistance to invasive growth (27). Not much is known on how exactly these genes exert their function.

Several mechanisms can be discriminated by which the normal regulating genes (the proto-oncogenes, tumor suppressor genes and modulating genes) are changed in their function and, so, might stimulate malignant transformation. These mechanisms consist of point mutations within the gene, genetic rearrangements within the coding sequence of the gene, genetic rearrangements outside the coding region and amplification or overexpression of the gene $(24,39)$. Also, there is some evidence that the product of one oncogene can influence the function of a different oncogene or its products (28).

There is evidence that the development of cancer is a multistep process. So, the alteration of proto-oncogenes into oncogenes (or the acquisition of oncogenes through viral infection) is not always sufficient to convert cells into full-blown tumor cells (40). It may well be that for this to occur, often a combination of oncogene expression, inactivation of tumor suppressor genes, and alteration of modulating genes is necessary. It might also well be that an until now not recognized additional mechanism is involved.

New molecular biologic techniques have confirmed the importance of cytogenetic analysis. Recurring chromosomal abnormalities have functioned as a clue for potentially important genes that could be detected using more sensitive approaches. However, they also have learned us that abnormalities can be present at the molecular level without changes detected using light-microscopy as in the conventional cytogenetic techniques. As an example, it is clear that a substantial subset of patients with a chronic myeloid leukemia without the $\mathrm{Ph}^{\mathrm{t}}$ chromosome, nevertheless has the bcr-abl translocation (41). A recent report (42) suggests that also in Hodgkin's disease a significant proportion of patients (32\%) has molecular evidence of $b c l-2 / J_{H}$ joining, as is observed in $t(14 ; 18)$, without having this translocation with conventional cytogenetic analysis.

It can be anticipated that further application of new technology from the molecular biology will reveal the existence of more chromosomal abnormalities in cytogenetically normal appearing cells. Also it may further contribute to the understanding of the biological mechanism of malignant transformation and growth. 
4 Chromosomal analysis and correlations with disease characteristics

As described in the previous sections, a number of specific chromosomal abnormalities have been found to correlate with particular diseases. The breakpoints in these abnormalities occurred at the sites of particular regulating genes. Therefore, these chromosomal abnormalities are not only of help for confirmation of the diagnosis. They might also be of importance in the pathogenesis and the behaviour of the disease as well as be related to response to therapy and to survival.

A substantial amount of work in this respect has been done in the field of the NHLs (43-57). Studies of lymph nodes involved by Hodgkin's disease have been more difficult. These difficulties are illustrative for a few of the problems encountered in the analysis of solid tumors (8). Chromosomal analysis of solid tumors has a low yield of abnormal metaphases. This problem is partially related to technical issues such as the preparation of an adequate tumor suspension, overt or cryptic infection of samples and problems of culturing the tumor cells. Also of importance is the low yield of viable cells, low mitotic activity and admixture of normal and/or reactive cells, like fibroblasts, lymphocytes and histiocytes (8). A different problem is related to the interpretation of the metaphases in solid tumors. In contrast to the leukemias often many abnormalities are observed in one cell; moreover the quality of the metaphases obtained is frequently poor. This makes the interpretation very difficult (8). The presence of several clones in one tumor cell population also occurs relatively frequently. An additional problem that is specific for Hodgkin's disease, deals with our insufficient knowledge how to recognize the malignant cell. These factors together might explain why relatively few reports have dealt with Hodgkin's disease and, in majority, were focussed on the numerical abnormalities (58-65). Correlations with pathologic and clinical characteristics of disease have not been described before. Such studies might be of help in answering the question whether the Reed-Stemberg cell is really the malignant cell in Hodgkin's disease and from which cell line it originates (66). There is still a lot of discussion whether this malignant cell is from lymphoid origin (B-or T-cell) or derived from the monocytoid/histiocytic lineage. A very recent report suggests that Reed-Sternberg cell is derived from the B-lymphocyte lineage because of the presence of the molecular counterpart of the $t(14 ; 18)$ translocation that is pathognomonic for many B-cell lymphomas (42). These questions urged us to study the chromosome data of patients with Hodgkin's disease analyzed in $\mathrm{Ne}$ braska (see Chapter 2).

In NHL several classic chromosomal abnormalities have been described like the already mentioned $t(2 ; 8), t(8 ; 14)$ and $t(8 ; 22)$ translocations in Burkitt NHL (11-14) and the t(14;18) translocation in the follicular NHLs (52). Numerous stu- 
dies have tried to find correlations between cytogenetic abnormalities and NHLsubgroups according to histology or immuno-phenotype (43-57). Several of these studies were hampered by low yields of abnormal metaphases, relatively low numbers of patients studied, the inclusion of patients analyzed at relapse instead of at initial diagnosis and the variability of treatment regimens used. Although some correlations between chromosomal abnormalities and disease characteristics like histology, extranodal localizations and survival have been observed, much less is known about the prognostic impact of karyotypic abnormalities in NHL in comparison to the acute leukemias. Therefore, an analysis of a large cohort of patients treated in a relatively homogeneous way was performed in an attempt to find previously not described chromosomal abnormalities and their correlations with characteristics of disease and already known non-chromosomal risk factors (see Chapter 3 ).

In the latter analysis the high incidence of abnormalities involving chromosome 6 drew our attention. Although several authors already observed the importance of specific abnormalities on chromosome 6, like del(6)(p23p24) (67) and del $(6 \mathrm{q})(51)$, the data on abnormalities of chromosome 6 in relation to disease characteristics are relatively scarce. Therefore, the patients with a NHL and an abnormal chromosome 6 were analyzed separately (see Chapter 4).

The introduction of immunophenotyping techniques has led to the description of a separate entity of NHL consisting of T-cells. It is not yet clear whether these lymphomas behave differently from the non-T-cell NHLs. Only a few studies have focussed on the relation between T-cell NHL and chromosomal abnormalities (68-75). Recent developments using techniques from molecular biology led to the recognition and later the localization of the genes coding for the T-cell receptor (76-81). The question is whether these genes are involved in the pathogenesis of this disease. A cytogenetic analysis of patients with these lymphomas could lead to more insight in the pathogenesis of this disease and tailoring of the treatment (see Chapter 5).

For many years chromosome studies have been performed in patients with acute myeloid leukemia (AML). Especially since the introduction of the high resolution banding techniques (6) the yield of abnormal metaphases has increased enormously. In several publications the frequency of patients with AML and an abnormal karyotype approaches 80 to $90 \%(82,83)$. These studies revealed cor relations between chromosomal abnormalities and particular subtypes of AML according to the French-American-British (FAB) classification (84). Subtype M2 was correlated with a $\mathrm{t}(8 ; 21)(85)$; $\mathrm{M} 3$ with $\mathrm{t}(15 ; 17)$ (86); abnormalities on chromosome 16 such as inv(16) and del(16q) with M4 with bone marrow eosinophilia (87); M5a with rearrangements of $11 \mathrm{q}$ (88) and abnormalities involving chromosomes 5 and 7 with secondary leukemias (89). Also from these studies correlations between the presence or absence of normal karyotypes and the 
likelihood of achieving a complete remission or the duration of this remission have been observed (90-94). Some authors (93) already proposed a classification based on the results of the cytogenetic study at diagnosis. Because the prognostic impact of cytogenetic characteristics may be related to or dependent on the therapy applied, we studied the importance of chromosomal abnormalities in patients with AML treated according to a protocol that also included bone marrow transplantation (see Chapter 6).

In the next chapters not only the frequency of chromosomal abnormalities in several hematologic malignancies are described but also the type of abnormalities discovered and, if possible, correlations between chromosomal abnormalities and characteristics of disease. The importance of a proper chromosomal analysis of hematologic malignancies at diagnosis will be emphasized. 


\section{References}

1. Tjio $\mathrm{JH}$, Levan $\mathrm{A}$ : The chromosome number of man. Hereditas $42: 1,1956$.

2. Boveri T: Zur Frage der Entstehung maligner Tumoren. Jena: Gustav Fischer. 1914. p 1.

3. Nowell $\mathrm{PC}$, Hungerford $\mathrm{DA}$ : A minute chromosome in human granulocytic leukemia. Science 132:1497, 1960.

4. Mitelman F: The Rous sarcoma virus story: cytogenetics of tumors induced by RSV. In: chromosomes and Cancer. Ed Geman J. New York: John Wiley \& Sons. 1974. p 675.

5. Sandberg AA: The chromosomes in human cancer and leukemia. New York: Elsevier/NorthHolland. 1980.

6. Caspersson $T$, Gahrton $G$, Lindsten $J$, Zach $\mathrm{L}$ : Identification of the Ph chromosome as a number 22 by quinacrine mustard fluorescence analysis. Exp Cell Res $63: 238_{i}, 1970$.

7. Mitelman F. Catalog of Chromosome Abernations in Cancer. Third Edition. New York: Alan R Liss, Inc. 1988 .

8. Teyssier JR. The chromosomal analysis of human solid tumors. A triple challenge. Cancer Genet Cytogenet 37:103, 1989.

9. Mitelman F. The human cancer chromosome registry. Second Intemationall Workshop on Chromosomes in Solid Tumors (abtract). Cancer Genet Cytogenet 28:32, 1987.

10. Trent JM. Chromosomal alterations in human solid tumors: Implications of the stem cell model to cancer cytogenetics. Cancer Surveys 3:395, 1984.

11. Zech L, Haglund U, Nilsson K, Klein G. Characteristic chromosomal abnomalities in biopsies and lymphoid-cell lines from patients with Burkitt and non-Burkitt lymphomas. Int J Cancer $17: 47,1982$.

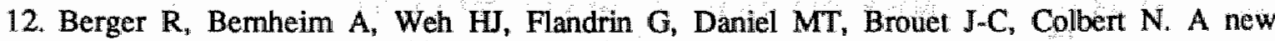
translocation in Burkitt's tumor cells. Hum Genet 53:111, 1979.

13. Miyoshi I, Hiraki S, Kimura 1, Miyamoto K, Sato J. 2/8 translocation in a Japanese Burkitt's lymphoma. Experientia 35:742, 1979.

14. Van den Berghe $H$, Parloir $C$, Gosseye $S$, Englebienne V, Comu G, Sokal G. Variant translocation in Burkitt lymphoma. Cancer Genet Cytogenet 1:9, 1979.

15. Yunis JJ, Ramsay N. Retinoblastoma and subband deletion of chromosome 13. Am J Dis Child $132: 161,1978$.

16. Rowley JD. A new consistent chromosomal abnomality in chronic myelogenous leukemia identified by quinacrine fluorescence and Giemsa staining. Nature 243:290, 1973.

17. Heisterkamp N, Stam K, Groffen J: Structural organization of the ber gene and its role in the $\mathrm{Ph}^{1}$ translocation. Nature $315: 758,1985$.

18. de Klein A, van Kessel A, Grosveld G, Bartram CR, Hagemeyer A, Bootsma D, Spurr NK, Heisterkamp N, Groffen J, Stephenson JK. A cellular oncogene is translocated to the Philadelphia chromosome in chronic myelocytic leukemia. Nature 300:765, 1982.

19. Groffen J, Stephenson JR, Heisterkamp N, de Klein A, Bartram CR, Grosveld G. Philadelphia chromosomal breakpoints are clustered within a limited region, bcr, on chromosome 22 . Cell $36: 93,1984$.

20. Gale RP, Cannani $\mathrm{E}$. The molecular biology of chronic myelogenous leukemia. Br J Haematol $60: 395,1985$.

21. Mclaughlin $\mathrm{J}$, Chianese $\mathrm{E}_{\text {" }}$ Witte $\mathrm{O}$. In vitro transformation of immature hematopoietic cells by the p210 BCR/ABL oncogene product of the Philladelphia chromosome. Proc Natl Acad Sct USA $84: 6558,1987$.

22. Dalla-Favera R, Bregni M, Erikson J, Patterson D, Gallo RC, Croce CM. Human c-myc onc gene is located in the region of chromosome 8 that is translocated in Burkitt lymphoma cells. Proc Natl Acad Sci USA 79:7824, 1982. 
23. Croce CM. Nowell PC. Molecular basis of Human B cell neoplasia. Blood $65: 1,1985$.

24. Burck KB, Lilu ET, Larrick JW. Oncogenes. An introduction to the concept of cancer genes. New York: Springer Werlag. 1988.

25. Knudson $\mathrm{AG}$ J. Mutation and cancer statistical study of retinoblastoma. Proc Natl Acad Sci USA $68: 820,1971$

26. Varmus HE, The molecular genetics of cellular oncogenes. Annu Rev Genet 18:553, 1984.

27. Friend SH, Dryja TP, Weinberg RA. Oncogenes and tumor-suppressing genes, $\mathbf{N}$ Engl J Med $318,618,1988$.

28. Druker BJ, Mamaon HJ, Roberts TM. Oncogenes, growth factors, and signal transduction. N Engl J Med 321 1383, 1989.

29. Yunis IJ. The chromosomal basis of human neoplasia. Science $221: 227,1983$.

30. Sager R. Tumor suppressor genes. the puzzle and the promise. Science 246:1406, 1989.

31. Hong FD, Huang HJ, To $H_{\text {, Oro }}$, Bookstein $R$, Lee EY, Lee WH. Structure of the human retinablastoma gene. Proc Nat1 Acad Sci USA 86:5502, 1989.

32. Huang HJS, Yee JK, Shew JY, Chen PL, Bookstein R, Friedmann T, Lee EY, Lee WH. Suppression of the neoplastic phenotype by replacement of the RB gene in human cancer cells. Science $242: 1563,1988$.

33. Cavenee WK, Dryja TP, Phillips RA, Benedict WF, Godbout R, Gallie BL, Murphen AL, Strong LC, White $\mathbb{R I}$. Expression of recessive alleles by chromosomal mechanisms in netinoblastoma. Nature 305:779, 1983.

34. Harris H. The genetic analysis of malignancy. J Cell Sci Suppl 4:431, 1986.

35. Chen PL, Scully $P$, Shew JY, Wang JYJ, Lee WH. Phosphorilation of the retinoblastoma gene product is modulated during the cell cycle and cellular differentiation. Cell $58: 1193,1989$.

36. Koi M, Afshari CA, Annab LA, Barrett JC. Role of a tumor-suppressor gene in the negative control of anchorage-independent growth of Syrian hamster cells. Proc Natl Acad Sci USA $86: 8773,1989$.

37. Rastinejad F, Polverini PJ, Bouck NP. Regulation of the activity of a new inhibitor of angiogenesis by a cancer suppressor gene. Cell 56:345, 1989.

38. Diaz MO, Rubin CM, Harden A, Ziemin S, Larson RA, Le Beau MM, Rowley JD. Deletions of interferon genes in acute lymphoblastic leukemia. N Engl J Med 322:77, 1990.

39. Bishop JM. The molecular genetics of cancer. Science $235: 305,1987$.

40. Land H, Parada LF, Weinberg RA. Cellular oncogenes and multistep cancinogenesis. Science $222: 771,1.983$.

41. Bartram CR, Carbonell F. BCR rearrangement in $\mathrm{Ph}^{1}$-negative $\mathrm{CML}$. Cancer Genet Cytogenet $21: 183,1986$.

42. Stetler-Stevenson $\mathrm{M}_{4}$ Crush-Stanton $\mathrm{S}_{n}$ Cossman J. Involvement of the bcl-2 gene in Hodgkin"s disease. J Natl Cancer Inst 82:855, 1990.

43. Yunis JJ" Frizzera G, Oken MM, McKenna J, Theologides A. Amesen M. Multiple recurrent genomic defects in follicular lymphoma. A possible model for cancer. N Engl J Med 316:79, 1987.

44. Juliusson $\mathrm{G}$. Immunologic and cytogenetic studies improve prognosis prediction in chronic Blymphocytic leukemia: A multivariate analysis of 24 wariables. Cancer 58:688, 1986.

45. Kaneko $Y$, Abe R, Sampi $K$, Sakuarai $M$. An analysis of chromosome findings in non-Hodgkin's lymphomas. Cancer Genet Cytogenet 5:107, 1982.

46. Kristoffersson U, Heim S, Mandahll $N_{\text {, }}$ Olsson $H$, Ranstam J, Akerman M, Miteiman F. Prognostic implication of cytogenetic findings in 106 patients with non-Hodgkin"s lymphoma. Cancer Genet Cytogenet 25:55, 1987.

47. Kaneko Y, Rowley JD, Variakojis D, Hanen JM, Ueshima Y, Daly K, Kluskens LF. Prognostic implications of karyotype and morphology in patients with non-Hodgkin's lymphoma. Int J Cancer 32:683, 1983. 
48. Juliusson G, Robèrt KH, Ost A, Friberg K, Biberfeld P, Nilsson B, Zech L, Gahrton G. Prognostic information from cytogenetic analysis in chronic B-lymphocytic leukemia and leukemic immunocytoma. Blood 65:134, 1985.

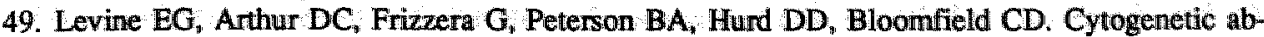
normalities predict clinical outcome in non-Hodgkin lymphoma. Ann Intem Med 108:14, 1988.

50. Levine EG, Arthur DC, Gajl-Peczalska KJ, LeBien TW, Peterson BA, Hurd DD, Bloomfield CD: Correlations between immunological phenotype and karyotype in malignant lymphona. Cancer Res 46:6481, 1986.

51. Fifth International Workshop on Chromosomes in Leukemia-Lymphoma. Correlation of chromosome abnormalities with histologic and immunologic characteristics in non-Hodgkin's lymphoma and adult $T$ cell leukemia-lymphoma. Blood 70:1554, 1987

52. Levine EG, Arthur DC, Frizzera G, Peterson BA, Hurd DD, Bloomfield CD. There are differences in cytogenetic abnormalities among histologic subtypes of the non-Hodgkin's lymphomas. Blood 66:1414, 1985.

53. Koduru PRK, Filippa DA, Richardson ME, Jhanwar SC, Chaganti SR, Koziner B, Clarkson BD, Lieberman PH, Chaganti RSK. Cytogenetic and histologic correlations in malignant lymphoma. Blood 69:97, 1987.

54. Bloomfield CD, Arthur DC, Frizzera G, Levine EG, Peterson BA, Gajl-Peczalska KJ. Non-random chromosome abnormalities in lymphoma. Cancer Res 43:2975, 1983.

55. Speaks SL, Sanger WG, Linder J, Johnson DR, Armitage JO, Weisenburger DD, Purtilo D. Chromosomal abnormalities in indolent lymphoma. Cancer Genet Cytogenet 27:335, 1987.

56. Sanger WG, Armitage JO, Bridge J, Weisenburger DD, Fordyce R, Purtilo DT. Initial and subsequent cytogenetic studies in malignant lymphoma. Cancer 140:3014, 1987.

57. Offit K, Richardson ME, Quanguang C, Hampton A, Kaduru PRK, Jhanwar SC, Filippa DA, Lieberman PH, Clarkson B, Chaganti RSK: Nonrandom chromosomal abberations are associated with sites of tissue involvement in non-Hodgkin"s lymphoma. Cancer Genet Cytogenet 37:85, 1989.

58. Kaplan HS. Hodgkin's disease. 2nd Edition. Cambridge, Massachusetts: Harvard University Press, 1980. p 52.

59. Sandberg AA. The lymphomas In Sandberg AA The chromosomes in human cancer and leukemia. New York: Elsevier, 1980, p 378.

60. Fleischmann J, Krizsa F. Chromosomes in malignant lymphoma (study on short term lymph node cultures). Haematologica 11:47, 1977.

61. Lawler SD, Swansbury GJ: Cytogenetic studies in Hodgkin's disease. In Selby $\mathbf{P}$ and McEIwain TJ (eds) Hodgkin's disease. Oxford: Blackwell Scientific Publications, 1987, p 43.

62. Slavutsky $I$, de Vinuesa ML, Estevez ME, Sen L, de Salum SB. Cytogenetic and immunologic phenotype findings in Hodgkin's disease. Canc Genet Cytogenet 114"123, 1985.

63. Rowley JD. Chromosomes in Hodgkin's disease. Cancer Treat Rep 66:639, 1982.

64. Hansmann ML, Gddde-Salz E, Pak-Kwan Hui, Müller-Hermelink HK, Lennert K. Cytogenetic findings in nodular paragranuloma (Hodgkin's disease with lymphocytic predominance; nodular) and in progressively transformed germinal centers. Cancer Genet Cytogenet 21:319, 1986.

65. Hossfeld DK, Schmidt CG. Chromosome findings in effusions from patients with Hodgkin's disease. Int J Cancer 21:147, 1978.

66. Cabanillas F, Pathak S, Trujillo J, Grant G, Cork A, Hagemeister FB, Velasquez WS, McLaughlin P, Redman J, Katz R, Butler JJ, Freireich EJ. Cytogenetic features of Hodgkin's disease suggest possible origin from a lymphocyte. Blood; 71:1615, 1988.

67. Mecucci C, Michaux JL, Tricot G, Louwagie A, van den Berghe H. Rearrangements of the short arm of chromosome no 6 in T-cell lymphomas. Leukemila Res 9:1139, 1985.

68. Bloomfield CD, Arthur DC, Frizzera G, Levine EG, Peterson BA, Gajl-Peczalska KJ. Nonrandom chromosome abnormalities in lymphoma. Cancer Res 43:2975, 1983. 
69. Lewine EG, Arthur DC, Gajl-Peczalska MI, LeBien TW, Peterson BA, Hurd DD, Bloomfield CD. Contelations between ummunological phenotype and karyotype in malignant lymphoma. Cancer Res 46:6481, 1986.

70. Fifth International Workshop on Chronosomes in Leukemia-Lymphoma. Correlation of chromosome abnomalities with histologic and immunologic characteristics in non-Hodgkin's lymphoma and adult $\mathrm{T}$ cell leukemia-Iymphoma. Blood 70.1554, 1987.

71. Berget $R$, Baranger $L$, Berheimm $A$. Vallensi $F$, Flandrin $G$ Cytogenetics of $T$-cell malignant lymphoma. Report on 17 cases and review of the chromosomal breakpoints. Cancer Genet Cytogenet $36: 123,1988$.

72. Takeuchi J, Ochi H, Mnowada J, Barcos M, Ozer $H_{*}$ Henderson ES, Sandberg AA. Cytogenetic studies of a diffuse mixed cell lymphoma of $\mathrm{T}$ cell origin. Cancer Genet Cytogenet 14:257, 1985.

73. Ueshima Y, Rowley JD, Variakojis D, Winter J, Gordon L. Cytogenetic studies on patients with chronic T cell leukemia/lymphoma. Blood 63:1028, 1984.

74. Lakalla-Paranko $T$, Franssila $K$, Lappalainen $K$, Leskinen $R$, Knutila $S$, de la Chapelle $A$, Bloomfield $\mathrm{CD}$. Chromosome abnormalities in peripheral $\mathrm{T}$-cell lymphoma. $\mathrm{Br} \mathrm{J}$ Haematol $66: 451,1987$.

75. Sanger WG, Weisenburger DD, Armitage JO, Purtilo DT. Cytogenetic abnormalities in noncutaneous peripheral T-cell lymphoma. Cancer Genet Cytogenet 23:53, 1986 .

76. Boehm I, Buluwela L, Williams D, White L, Rabbitts TH. A cluster of chromosome p13 translocations found via distinct D-D and D-D-J rearrangements of the human T-cell receptor d-chain gene. EMBO J 7:2011, 1988.

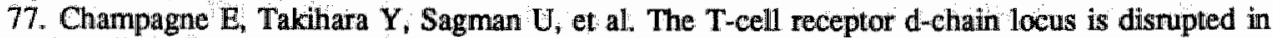
the T-ALL associated $t(1,14)(\mathrm{p} 13 ; \mathrm{q} 11)$ translocation. Blood 73:1672, 1989.

78. Boehm 'T, Baer R, Lavenir I, et al. The mechanism of chromosomal translocations at $t(11 ; 14)$ involving the $\mathrm{T}$-cell receptor Cd-locus on human chromosome $14 \mathrm{q} 11$ and a transcribed region of chromosome 11 p15. EMBO J 7:385, 1988.

79. Rabbits TH, Lefranc MP, Stinson MA, et al. The chromosomal location of T-cell receptor genes and a $T$ cell rearranging gene: possible correlation with specific translocations in human $T$-cell leukemia. EMBO J 4:1461, 1985.

80. Barker PE, Ruddle FM, Royer HD, Acuto O, Reinherz EL. Chromosomal locations of human T-cell receptor gene Ti beta. Science 226:348, 1984.

81. Reynolds TC, Smith SD, Sklar J. Analysis of DNA surrounding the breakpoints of chromosomal translocations involving the Beta $\mathrm{T}$ cell receptor gene in human lymphoblastic neoplasms. Cell $50: 107,1987$.

82. Yunis JJ "Recurrent chromosomal defects are found in most patients with acute nonlymphocytic leukemia. Cancer Genet Cytogenet 11:125, 1984.

83. Misawa $\mathbf{S}$, Hogge DE, Oguna $\mathbf{N}_{v}$ Wiemik $\mathbf{P H}$. Testa $\mathrm{JR}$. Detection of clonal karyotypic abnormalities in most patients with acute nonlymphocytic leukemia examined using short-term culture techniques. Cancer Genet Cytogenet 22:239, 1986.

84. Bennett JM, Catovsky D, Daniel MT, Flandrin G, Galton DAG, Gralnick HR, Sultan C. Proposed revised criteria for the classification of acute myeloid leukemia. Ann Intern Med 103:620, 1985.

85. Rowley $\mathrm{JD}$. Identification of a translocation with quinacrine fluorescence in a patient with acute leukemia Ann Genet 16:109, 1973.

86. Larson RA, Kondo $\mathrm{K}$, Vardiman JW, Butler AE, Golomb HM, Rowley JD. Evidence for a 15;17 translocation in every patient with acute promyelocytic leukemia. Am J Med 76:827, 1984.

87. LeBeau MM, Larson RA, Bitter MA, Vardiman JW, Golomb FM, Rowley JD. Association of an inversion of chromosome 16 with abnormal marrow eosinophils in acute myelomonocytic leukemia. N Engl J Med 309:630, 1983. 


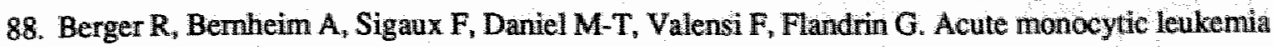
chromosome studies. Leukemia Res 6: 17, 1982.

89. Wilmoth D, Feder M, Finan J, Nowell P. Preleukemia and leukemia with $12 \mathrm{p}$ and $19 \mathrm{q}$ * chromosome alterations following alkeran therapy. Cancer Genet Cytogenet $15: 95,1985$.

90. Berger $R$, Bemheim $\mathrm{A}$, Ochoa-Noguera $\mathrm{ME}$, Daniel MT, Valensi $F$, Sigaux $F$, Flandrin $G$, Boiron M. Prognostic significance of chromosomal abnormalities in acute nonlymphocytic leukemia: a study of 343 patients. Cancer Genet Cytogenet 28:293, 1987.

91. Keating MI, Cork A, Broach Y, Smith T, Walters RS, McCredie KB, Trujillo J, Freireich $\mathbb{E}$. Toward a clinically relevant cytogenetic classification of acute myelogenous leukemia. Leukemia Res 11:119, 1987.

92. Larson RA, LeBeau MM, Vardiman JW, Testa JR, Golomb HM, Rowley JD. The predictive value of initial cytogenetic studies in 148 adults with acute nonlymphocytic leukemia: a 12-year study (1970-1982). Cancer Genet Cytogenet 10:219, 1983.

93. Keating MJ, Smith TL, Kantarjian H, Cork A, Walters R, Trujillo JM, McCredie KB, Gehan EA and Freireich $\mathbb{E}$. Cytogenetic pattem in acute myelogenous leukemia: a major reproducible determinant of outcome. Leukemia $2: 403,1988$.

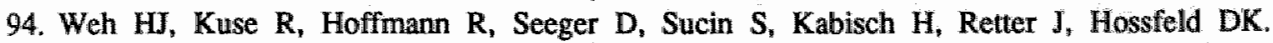
Prognostic significance of chromosome analysis in the novo acute myeloid leukemia (AML). Blut 56:19, 1988. 


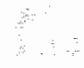

$a$
3
3
$\square$ 


\section{CHAPTER 2}

\section{Chromosomal abnormalities in Hodgkin's disease}

Harry C. Schouten, Warren G. Sanger, Michael Duggan, Dennis D. Weisenburger, Ken A. MacLennan, James O. Armitage.

Blood 1989, 73: 2149.2154 
Y Abstract

Numerous neoplastic states have associated or causal cytogenetic abnormalities. In some cancers, specific chromosomal abnormalities appear to correlate with the clinical characteristics and prognosis. Cytogenetic analysis of Hodgkin's disease is thought to be technically difficult and only a small number of cases with evaluable results have been reported. We have attempted cytogenetic studies of lymph nodes from 37 patients with Hodgkin's disease. In 29 of the 37 patients (78\%), successful chromosomal analysis was accomplished. Chromosomal abnormalities were found in 13 patients (45\%); five of these patients had been previously treated with chemotherapy. Numerical changes were found in all patients, most commonly involving chromosomes \#5, 9, 15, 18, 22, X, and marker chromosomes. Seven patients also had structural abnormalities. The breakpoints $4 q 32-34,6 q 24,12 q 13,12 q 23-24$ and 13p11-13 were each seen in at least two patients. All but two patients had an admixture of normal cells. Three patients had two or more clones, and one had subclones. No statistically significant correlations between chromosomal abnormalities and clinical characteristics were demonstrated, although the number of patients in each subgroup was small. We conclude that chromosomal studies of Hodgkin's disease are likely to be successful. Additional studies are needed to correlate the karyotypical abnormalities in Hodgkin's disease with clinical and biological characteristics.

\section{Introduction}

In 1914, Theodor Boveri hypothesized that all cells of a malignant tumor had karyotypic alterations and that any event leading to such chromosomal abnormalities would result in a malignant tumor (1). Several diseases now have been found to have related cytogenetic abnormalities. At least $85 \%$ of patients with chronic myelogenous leukemia have a $t(9 ; 22)$ translocation (2), and most patients with Burkitt's lymphoma have a $t(8 ; 14), t(2 ; 8)$ or $t(8 ; 22)(3)$. A $t(14 ; 18)$ is known to be correlated with follicular non-Hodgkin's lymphomas (4). Certain cytogenetic abnormalities have been related to different treatment results as in non-Hodgkin's lymphoma (5). In acute leukemia some subtypes have been correlated with particular structural cytogenetic changes (6) or numerical abnormalities (7).

In contrast to the non-Hodgkin's lymphomas, only a few reports of cytogenetic abnormalities in patients with Hodgkin's disease are present in the literature; these have been largely summarized by Kaplan (8) and Sandberg (9) and have consisted mostly of numerical abnormalities. Only a few studies have 
reported chromosomal analysis with banding techniques of lymph nodes involved by Hodgkin's disease (10-16).

We performed chromosomal analysis of lymph nodes of 37 patients with Hodgkin's disease, to assess the types and the frequencies of chromosomal abnormalities, and their relationship to the histologic features and treatment outcome.

\section{Y Materials and Methods}

\section{Patient Characteristics}

Between November 1, 1982 and April 1, 1988, the lymph node biopsies from 37 patients with histologically-confirmed Hodgkin's disease were studied cytogenetically. All of the lymph nodes were involved by lymphoma. The characteristics of the patients are given in Table I. A modified Rye histologic classification was used (17): nodular sclerosis subtype M1 (NS-M1), subtype M2 (NS-M2), subtype mixed cellularity (NS-MC), subtype lymphocyte depleted (NS-LD), mixed cellularity (MC), lymphocyte depleted (LD), lymphocyte predominant subtype diffuse (LP-D) and subtype nodular (LP-N). Staging consisted of a complete history and physical examination, chest radiograph, computed tomography scan of the abdomen and chest, and bilateral bone marrow biopsies. If abnormal liver function tests were present, a liver biopsy was performed. A staging laparotomy was performed if it may have resulted in a change of treatment. The patients were staged according to the Ann Arbor system (18); five patients were stage IA, one was stage IB, seven were stage IIA, one was stage IIAE, three were stage IIB, six were stage IIIA, two were stage IIIB, one was stage IIIBE, seven were stage IVA, and four were stage IVB (Table I).

In 30 patients, the tumor was studied either at the time of primary diagnosis or at relapse after local radiation therapy with the newly-involved node being outside the previously irradiated area. Seven other patients were studied in relapse. No selection criteria other than the availlability of cytogenetic data was used. A piece of each tumor was also submitted for histologic analysis.

\section{Treatment}

The choice of treatment depended upon the stage (Table I). Patients with pathologically-confirmed stage I disease were treated with radiation therapy. Among the patients with stage II and III disease six were treated with radiation therapy and six with chemotherapy, while eight were treated with combined modality therapy. All patients with stage IV disease were treated with chemotherapy, and nine also received radiation therapy. The chemotherapy regimes consisted of ChIVVP (chlorambucil, vincristine, procarbazine and prednisone) 
Table I. Characteristics and Response to Treatment of 29 Patients With successful Chromosomal Studies

\begin{tabular}{|c|c|c|c|c|c|c|c|}
\hline & $\begin{array}{l}\text { Agar } \\
\text { Sex }\end{array}$ & $\begin{array}{l}\text { Histology } \\
+ \text { Stage(1) }\end{array}$ & $\begin{array}{l}\text { Bullky } \\
\text { Disieasole }\end{array}$ & $\begin{array}{l}\text { Exrranodal } \\
\text { Disease(a) }\end{array}$ & Jreatment 4 ) & Fiesponse(5) & DFS $[6]$ \\
\hline 1 & $55 \mathrm{M}$ & WSLD IIB & $*$ & . & ChNPP & $\mathrm{CR}$ & 3 \\
\hline 2 & $29 M$ & NSS-MU UIA & 4 & - & ChNPP+AT & CR & $55+$ \\
\hline 3 & $28 / F$ & NSLLDIIA & * & * & RT & $C R$ & 34 \\
\hline 4 & $32 \pi$ & WS-M1 HIBE & * & * & ChNPP $+\mathrm{AT}$ & CR & 2 \\
\hline 5 & $20 \mathrm{M}$ & NS-MU IVA & * & * & ChNPP $+R T$ & $\mathrm{CA}$ & 4 \\
\hline 6 & $26 / F$ & NS-M2 IA & - & “ & RT & $\mathrm{CR}$ & $4+$ \\
\hline 7 & $25 / \mathrm{f}$ & NS-M2 $\| A$ & + & - & RT & $\mathrm{CR}$ & 40 \\
\hline - & $82 / F$ & MO IA & NA & 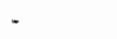 & AT & $\mathrm{CA}$ & 55 \\
\hline c. & $23 F$ & MSHC VVA & + & + & MOPP * RT & $\mathrm{CP}$ & 19 \\
\hline 10 & $32 M$ & NS-LDNA & 4 & + & MOPP/ABVD + RT & $\mathrm{CA}$ & 12 \\
\hline 11 & $25 / \mathrm{M}$ & NS-M2 IIB & MA & " & MOPP & $C R$ & 6 \\
\hline 12 & $87 / F$ & MS-MC UB & * & 3 & CANPP & $C R$ & $50+$ \\
\hline 13 & $56 / F$ & LD IVB & NA & NA & LWDPB & NA & NA \\
\hline 14 & $18 / \mathrm{F}$ & $M C I A$ & 4 & - & AT & $C R$ & $50+$ \\
\hline 15 & $34 M$ & LPPN & . & . & FT & $\mathrm{CA}$ & $0_{+}$ \\
\hline 16 & $30 \mathrm{M}$ & MCIVA & + & + & ChNPP + RT & $\mathrm{PR}$ & 0 \\
\hline 17 & $21 / M$ & NS-M2 ILA & + & . & RT & $C R$ & $13+$ \\
\hline 18 & $16 / F$ & NS-LO IIB & + & + & ChNPP + RT & CR & $19+$ \\
\hline 19 & $45 M$ & NSELO WA & + & + & ChNPP + RT & $C R$ & $4+$ \\
\hline 20 & $19 \mathrm{M}$ & NS-M2 lVB & + & + & ChNPP + RT & $\mathrm{PA}$ & 0 \\
\hline 21 & $38 M$ & NS-M2 ILAE & + & + & ChINPP + RT & CR & $6+$ \\
\hline 22 & $62 \mathrm{M}$ & MC IVB & + & + & ChNPP + RT & NR & 0 \\
\hline 23 & $24 M$ & NS-M\|I IB & + & . & ChNPP & $\mathrm{CR}$ & $58+$ \\
\hline 24 & $19 / N$ & NS-M2 IIIA & + & $=$ & ChNPP & $P R$ & 0 \\
\hline 25 & $64 \mathrm{M}$ & LP-N $\| A$ & - & - & AT & $C R$ & $42+$ \\
\hline 26 & $16 \mathrm{M}$ & NS-M2 INA & + & $*$ & ChNPP + RT & PA & 0 \\
\hline 27 & $19 / F$ & MC IVA & + & * & ChNPP + RT & CR & $I_{+}$ \\
\hline 28 & $36 \mathrm{M}$ & NS-LD \|A & . & . & ChNPP + RT & $C R$ & $35+$ \\
\hline 29 & $23 \mathrm{M}$ & NS-M\|IA & + & - & RT & $\mathrm{CR}$ & 3 \\
\hline
\end{tabular}

Patients (1-13) had abnormal and patients (14-29) normal karyotypes.

1 NS-LD: Nodular sclerosis, lymphocyte depleted; NS-M1: Nodular sclerosis type M1; NS-M2: Nodular sclerosis type M2; NS-MC: mixed cellularity; MC: mixed cellularity; LD: tymphocyte depleted; LP-N: Iymphocyte predaiminant, nodular ("17)

2 Bulky disease: diamater more than $5 \mathrm{~cm}$; + : present; - absent; NA: no data avallable

3 +: presenti; *: absent; NA: no data avallable

4 First treatmont atter diagnosis:

ChlVPP: chlorambucil, vincristine, procarbazine, prednisone;

RT: radiotherapy;

MOPP: mechlorethamino $\theta_{i}$ vincristine, procarbazine, prednisone;

MOPP/ABVD": altemating MOPP and adriamycin, bleomycin, vinblastine, DTIC;

LVDPB: lomustine, vincristine, dexamethasone, procarbazine, bleomycin

5. After first treatment regimen CR: complete response; PA: partial response; NR: no response; NA: no data availlabl:

6 DFS: diserase free survival (months)

(19), MOPP (mechlorethamine, vincristine, procarbazine, and prednisone) (20), alternating MOPP with ABVD (adriamycin, bleomycin, vinblastine and 
dacarbazine) (21), or a combination of lomustine, vincristine, dexamethasone, procarbazine and bleomycin.

A complete remission (CR) was defined as the absence of clinically demonstrable disease after the completion of the therapy and restaging. Diseasefree survival was defined as the period of time from CR until relapse, death or present.

\section{Cytogenetic Methods}

The methods of culturing and processing of the lymph nodes are described elsewhere (22). In short, after mechanically mincing the tissue in RPMI 1640 (Gibco, Grand Island, NY) including 20\% fetal bovine serum and antibiotics the cell suspensions were incubated at $37.5^{\circ} \mathrm{C}$ and cultured for 24 and 48 hours without the use of mitogens. After the exposure to Colcemid ( $0.05 \mathrm{ug} / \mathrm{ml}$ )(Gibco, Grand Island, NY), the preparations were resuspended in 0.074 molar KCL for 10 minutes and fixed with a 3:1 mixture of methanol and glacial acetic acid. After repeating the fixation process three times, the slide preparations were made, aged overnight at $60^{\circ} \mathrm{C}$ and G-banded with Wright's stain. All metaphase plates were microscopically analyzed, recorded, and photographed. An abnormal clone was defined as two or more cells with the same structural abnormality or the same extra chromosome, or the presence of three or more cells with the same missing chromosome. If only one mitotic cell with an abnormal karyotype was present it was considered a malignant clone if there was structural abnormality known to be associated with lymphoma. Normal cells were considered to be present if a single cytogenetically normal cell was seen. If these criteria were not fulfilled or less than 5 normal mitotic cells were present or the results were to poor to analyze, the test was classified as inconclusive. The karyotypes were designated according to the classification of the International System for Human Cytogenetic Nomenclature (ISCN 1985)(23). The cytogenetic abnormalities were mapped and their relative frequencies calculated. The results of the chromosome studies were correlated with the histologic diagnosis and clinical characteristics.

\section{Results}

In 29 of the 37 patients (78\%), successful cytogenetic studies were accomplished and in eight patients the results were inconclusive. In 13 of the 29 $(45 \%)$, the results were abnormal (Table II). In 16 of 29 patients (55\%), normal karyotypes were found. Patients with successful studies had the following histologic diagnosis: NS-M1 $(n=5)$, NS-M2 $(n=8)$, NS-MC $(n=2)$, NS-LD $(n=6)$; $M C(n=5) ; L D(n=1)$; and LP-N $(n=2)$. The patients with inconclusive results had NS-M2 $(n=2)$, MC $(n=3)$, LP-D $(n=1)$, LP-N $(n=1)$ and LD $(n=1)$. Only one 
Table II. Results of Cytogenetic Studies

Pat Colls analyzed

No Nomal Abnomal Karyotype

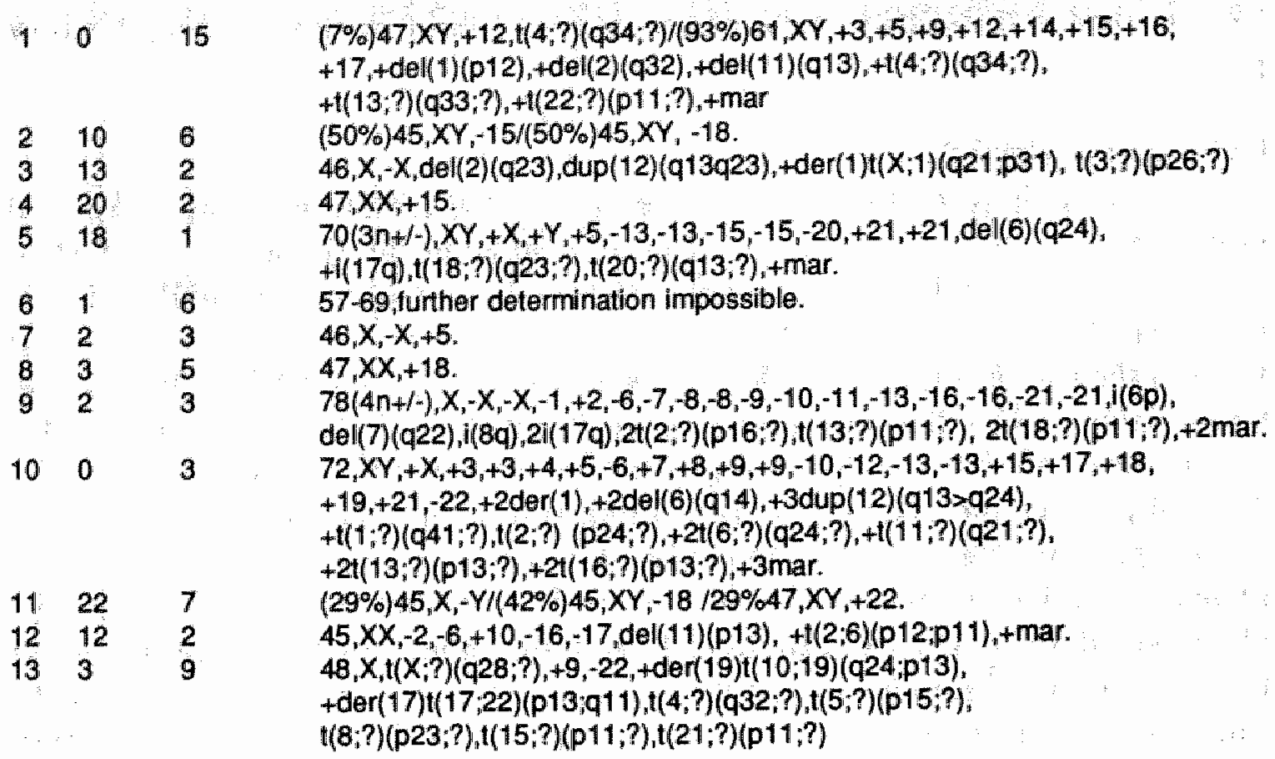

of the patients from the latter group was treated before the cytogenetic study. The numbers of patients with gains and losses of complete chromosomes and marker chromosomes are given for each chromosome. Of the patients with successful cultures, 21 had the cytogenetic studies at the time of diagnosis (Table I, cases 1-6 and 14-28) and three patients (cases $7 \& 8$ and 29) at the time of relapse. However all these of the latter patients had been treated with radiation therapy alone, and the lymph node which was analyzed had not been previously irradiated. Therefore, the abnormalities in these three patients were considered not to be therapy-induced. Patients 9-13 were studied after treatment with combined modality therapy and, therefore, therapy-induced abnormalities cannot be excluded.

In two patients, cases 1 and 10, only abnormal metaphases were obtained; all other patients had an admixture of normal cells. All abnormal cultures had numerical abnormalities. Cultures from eight patients were hyperdiploid (47-80 chromosomes) and three were hypodiploid (45 chromosomes). Most frequently, gains of chromosomes \#3,5,9 and 15 were observed, but gains of chromosomes $\# 4,10,12,14,17,18,19,21,22$ and $X$ were also seen in two patients each (Figure 1). In five patients, marker chromosomes were present. Monosomies 


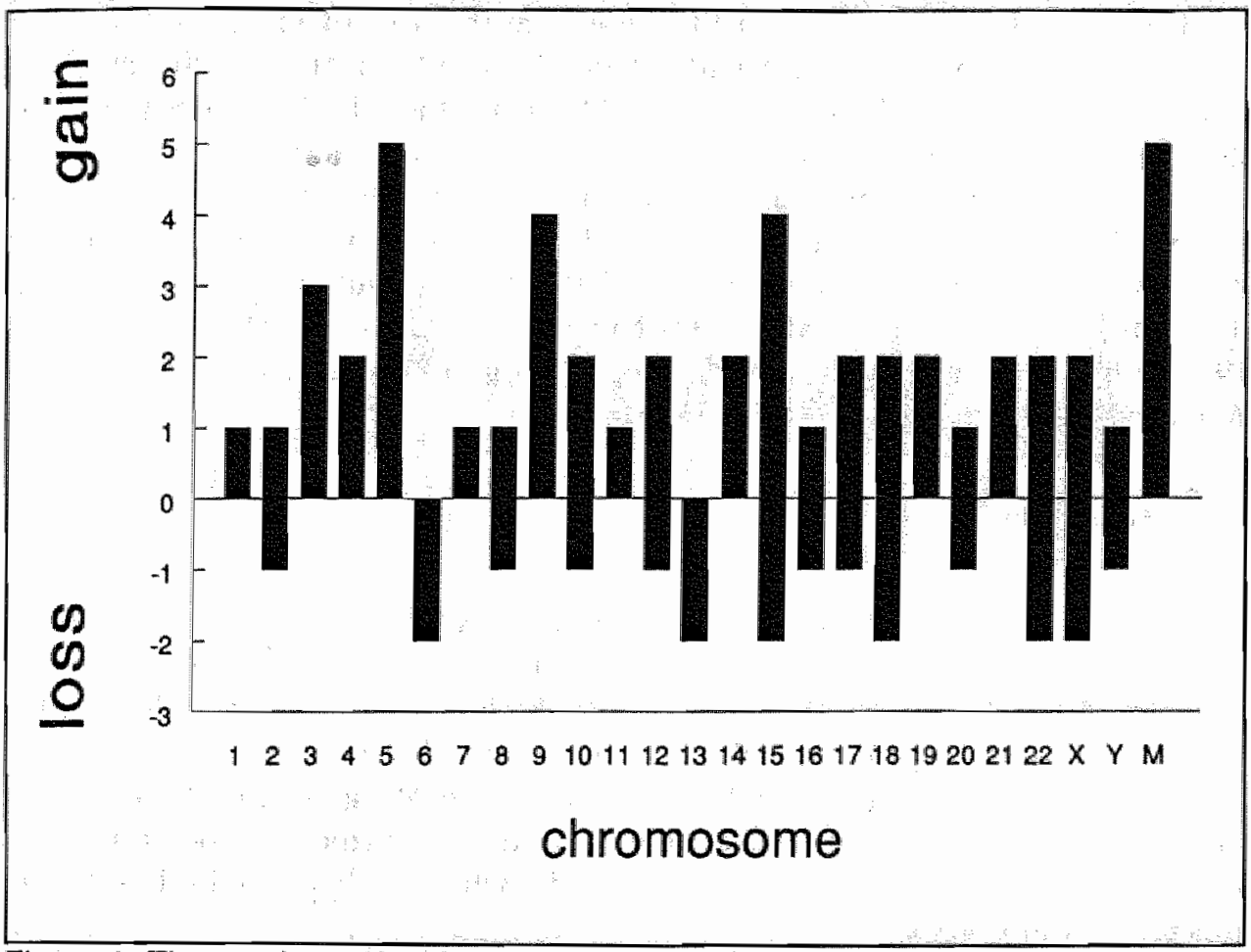

Figure 1. The numbers of patients with gains and losses of complete chromosomes and marker chromosomes are given for each chromosome.

were also found, and occurred more than once in chromosomes \#6,13,15,18, 22 and $X$. Combining these numerical abnormalities, the chromosomes $\# 5,9,15$, 18,22 , and $X$ were each involved in at least four patients. In addition to these abnormalities, structural abnormalities were also present in seven patients. Several of these structural abnormalities occurred only once. However, a translocation involving breakpoint $4 \mathrm{q} 32-34$ was found in two patients (cases 1 and 13 ), breakpoint $6 \mathrm{q} 24$ was involved in one translocation and one deletion (cases 5 and 10), and breakpoint 13p11-13 was involved in two patients (cases 9 and 10). Breakpoints $12 \mathrm{q} 13$ and $12 \mathrm{q} 23-24$ were each involved in two patients (cases 3 and 10), both as a part of a dup(12)(q13->q23-24). All other chromosomes except \#9, 14 and $Y$ were each involved in at least one patient, however no consistent breakpoint was observed. The distribution of the structural chromosomal abnormalities is given in Figures 2 and 3. There is no clear difference between the patients before or after treatment. Three patients (cases 1,2 and 11) appeared to have two or more cytogenetically abnormal clones of malignant cells. 
The clinical characteristics of the patients at the time of initial diagnosis, or at the time of relapse in those without previous radiotherapy on the involved node or chemotherapy (cases 1-8 and 14-29) were studied. There appeared to be no significant differences between the cytogenetically normal and abnormal groups with regards to histology, B symptoms, stage, the presence of bulky or extranodal disease, achievement of a $C R$, or relapse rate. The disease-free survivals for the patients with normal and abnormal karyotypes were calculated. The cytogenetically abnomal patients had a longer median disease-free survival ( 9 months) than those with normal results ( 3.5 months) but this difference was not significant using the Chi Square test.

Y Discussion

In contrast to the leukemias and non-Hodgkin's lymphomas, few cytogenetic studies in Hodgkin's disease have been reported due to the technical difficulties inherent to the disease (8). In a summary of the literature, prior to 1980, Kaplan (8) reported 100 cases of Hodgkin's disease and chromosomal abnormalities, with the most striking findings being the presence of numerical abnormalities and marker chromosomes. These findings were confirmed by other reviews $(9,14)$. Rowley (24) also described 25 patients who had hyperdiploid cells and marker chromosomes.

Although numerical abnormalities have been frequently reported, studies dealing with structural chromosomal changes in Hodgkin's disease are few. Only a few studies have used banding techniques to study lymph nodes involved with Hodgkin's disease. Fukahara and Rowley (10) described one patient with a $\mathrm{t}(1 ; 14)(\mathrm{q} 2 ; \mathrm{q} 32)$, along with other non-specified rearrangements. Hansmann (25) reported one patient with hyperploidy, a $6 \mathrm{q}-$ abnormality and several marker chromosomes. Fleischmann and Krisza (11) reported one patient with a del(9)(p11q11), whereas, Reeves et al $(12,13)$ studied the nodes of five patients and found a variety of structural abnormalities involving the breakpoints $1 \mathrm{q} 32$, $2 \mathrm{p} 13,3 \mathrm{p} 13,3 \mathrm{p} 21$ or $23,5 \mathrm{q} 31,6 \mathrm{q} 13$ or $15,6 \mathrm{q} 21,6 \mathrm{q} 23$ or $25,7 \mathrm{q} 11,9 \mathrm{q} 11,9 \mathrm{q} 31$, $10 q 26,12 q 22$ and $14 q 32$, and inversions of $2 q, 18 p$ and $18 q$. Lawler and Swansbury (14) studied four patients and found in one patient paracentric inversion of $5 q, 10 q, 21 q$ in addition to gains of parts of long and short arms of chromosome \#4, 10 and 11, not further specified. Slavutsky et al (15) described one patient with a $t(X ; 6)(q 12 ; q 13)$, and another patient with a del(5)(p15) in addition to numerical abnormalities. Cabanillas et al (16) observed frequently occurring abnormalities located on $11 \mathrm{q} 23,14 \mathrm{q} 32,6 \mathrm{q} 11-21,8 \mathrm{q} 22-24$, and 11q13.

We report the chromosomal abnormalities of 13 of 37 patients in whom chromosomal analysis was performed. All 13 patients had numerical abnormalities and seven also had structural changes. Chromosomes frequently gained are 


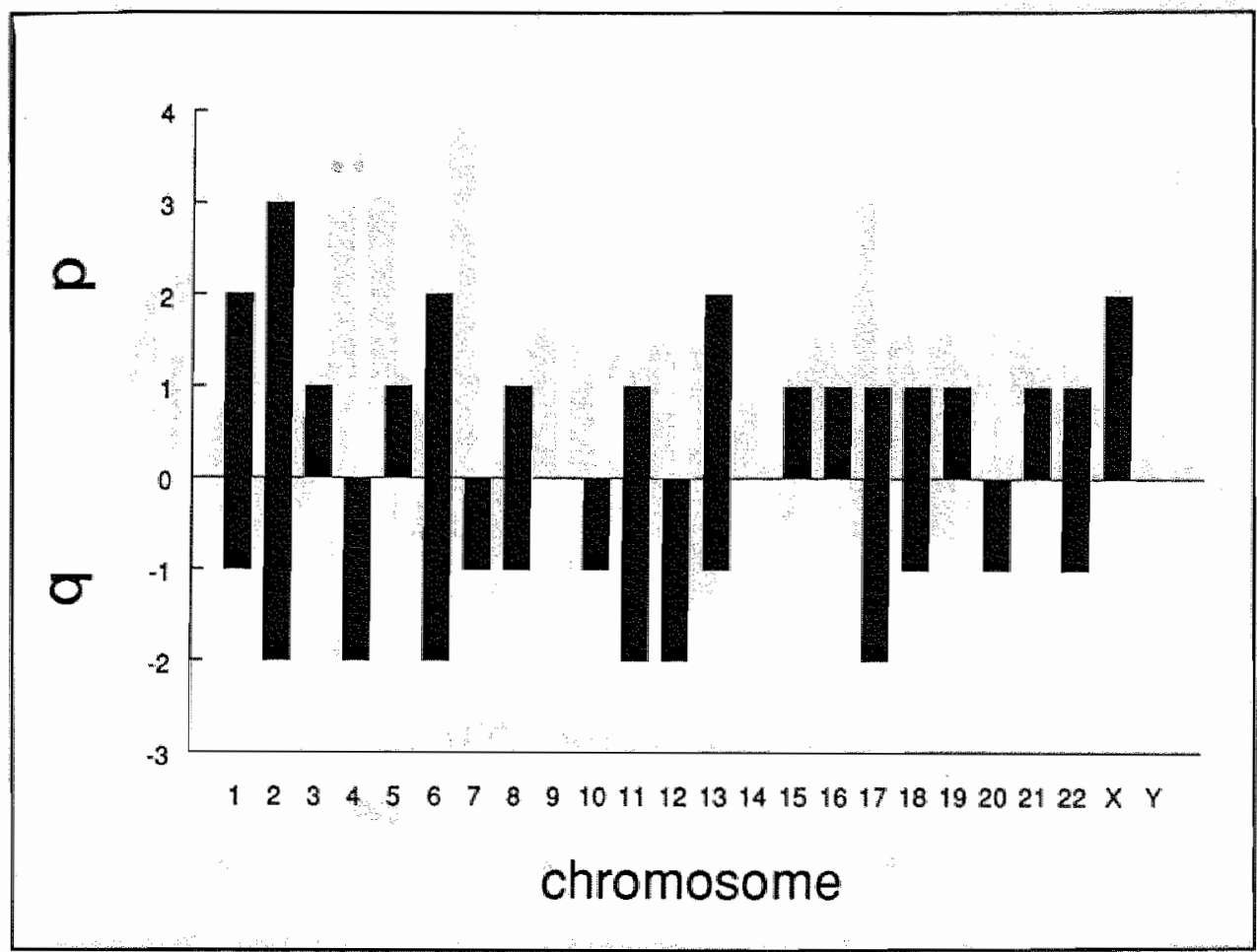

Figure 2. The numbers of patients with structural abnormalities of $p$ and $q$ arms for each chromosome are shown.

$\# 5,9,15,18,22$, and $X$ while less frequently gained chromosomes are $\# 3,10$, 12 , and 17 (each in at least three patients). The structural abnormalities that we found were more random than those found in the group with numerical changes, however the breakpoints $4 \mathrm{q} 32-34,6 \mathrm{q} 24,12 \mathrm{q} 13,12 \mathrm{q} 23-24$, and 13p11-13 were each observed in more than one patient.

Numerical and structural abnormalities of chromosome \#2 are considered to be very infrequent in malignancies (26). However, we found chromosome $\# 2$ involved in five patients, two with numerical and structural abnormalities and three with only structural abnormalities, however, there was no consistent breakpoint. We also found an additional chromosome \#5 and a translocation involving chromosome \#6 in a higher than expected frequency in Hodgkin's disease. Also, we observed chromosome \#22 involved in 5 of 13 patients with Hodgkin's disease, but the change was usually numerical other than structural. The known abnormalities of the non-Hodgkin's lymphomas as $t(8 ; 14), t(11 ; 14), t(14 ; 18)$ did not occur in our series in contrast to Cabanillas et al (16). However, our results and those from the literature suggest a large variety of chromosomal ab- 


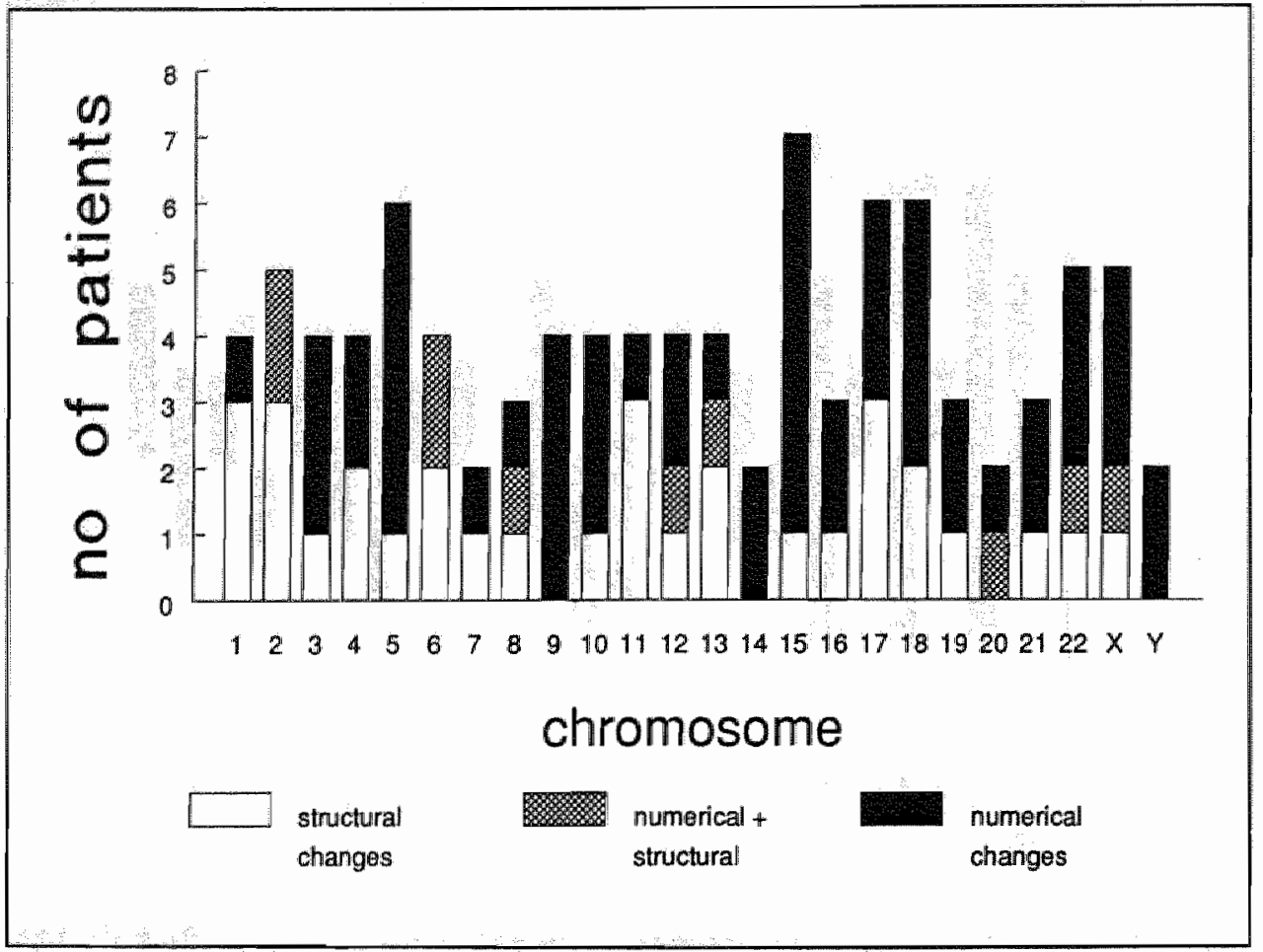

Figure 3. The numbers of patients with structural or numerical changes of each chromosome and in the same chromosome are shown. This figure also demonistrates the trequency of involvement of a particular chromosome in all patients.

normalities involved.

From the cytogenetic studies of patients with non-Hodgkin's lymphoma, it is known that the chromosomal breakpoints correspond with the location of a variety of oncogenes (5). Activation of these oncogenes has been suggested as playing a role in the development of these malignancies $(5,27)$. These correlations have not been described for Hodgkin's disease, although Cabanillas et al (16) recently suggested correlations with $c$-ets, $c-m y b, c-m y c, b c l-1$ genes and the immunoglobulin heavy chain gene. The breakpoints that we observed to be involved in more than one patient are not known to be the sites of recognized oncogenes, except for the myb oncogene at $6 \mathrm{q} 24$ (28).

In our study, the yield of successful metaphases; and especially abnormal metaphases, is higher than that reported in the literature $(8,14,24)$. It is generally believed that the low mitotic rate of the neoplastic cell in Hodgkin's disease is responsible for this phenomenon $(8,24)$, although a relationship between unsuccessful cytogenetic studies and the nodular sclerosis histology has also been 
suggested (8,24). Studies using pleural effusions reportedly have a higher success rate (29). However, there also appears to be a discrepancy in karyotypic abnormalities between the lymph nodes and such effusions (24). In our study, however, we found a high success rate of chromosomal studies in patients with the nodular sclerosis type $(75 \%)$, with $52 \%$ of the cases being abnormal. Also, in all but two patients, a mixture of karyotypically normal and abnormal cells was found. This is in agreement with other studies $(8,24)$. Of the patients with the inconclusive results only one had been treated previously with chemotherapy, making a causal relationship unlikely. With the cytogenetic techniques currently used, however, it was not possible to determine whether surrounding normal lymphocytes or other cells were the chromosomally normal cells. Also it is not possible, based on our results, to exclude that the surrounding lymphocytes are the dividing cells with chromosomal abnormalities and thus, part of the malignant clone. The application of other techniques as in situ analysis or flow cytometry can be of help to solve this issue.

An extensive analysis correlating clinical features such as the histologic type, presence of B symptoms, stage, presence of bulky disease or extranodular disease, ability to achieve a $\mathrm{CR}$, and the relapse rate with the presence or absence of abnormal chromosomes did not reveal any significant correlations. Also, the disease-free survival was not significantly different for the two groups. Further studies are needed to determine whether correlations between chromosomal abnormalities and disease characteristics in Hodgkin's disease exist.

In contrast to reports in the literature, we conclude that cytogenetic analysis in Hodgkin's disease is possible with current culture techniques, and reveals chromosomal abnormalities in a significant number of patients. However, cytogenetic techniques have to be further improved to fulfill the Boveri hypothesis (1). Because of the small number of patients in each subgroup, we were unable to demonstrate correlations between the chromosomal abnormalities and histological or clinical characteristics. However, our findings suggest that further studies of a large number of patients should be performed. 
1 References

1. Boweri $\mathrm{T}$ Zur Frage der Entstehung maligner Tumonen Jena. Gustav Fischer. 1914, p 1

2. Nowell PC, Hungerford DA. A minute chromosome in human chronic granulocytic leukemia. Seience $132: 1497,1960$ (letter)

3. Lenoir $\mathrm{GM}$, Preud honme $\mathbf{J L}$, Bernheim $\mathrm{A}$, Berger $\mathbf{R}$. Correlation between immunoglobulin light chain expression and wariant translocation in Burkitt's lymphoma Nature 298:474, 1982

4. Yunis JI, Oken MM, Kaplan ME, Ensrud KM, Howe, RR, Theologides A. Distinctive chromosomal abnomalities in histologic subtypes of non-Hodgkin's lymphoma. N Engl J Med $307: 1231,1982$

5. Levine EG, Arthur DC, Frizzera $G$, Peterson B, Hurd DD, Bloomfield CD. Cytogenetic abnormalities predict clinical outcome in non-Hodgkin"s lymphoma. Ann Int Med 108:14, 1988

6. Rowley $\mathrm{D}$, Alimena $\mathrm{G}$, Garson OM, Hagemeyer A. Mitelman F, Prigogina EL. A collaborative study of the relationship of the morphological type of acute nonlympocytic leukemia with patient age and karyotype. Blood 59:1013, 1982

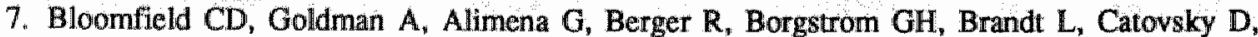
delaChapelleA, Dewald GW, Garsop OM, Garwies S Golomb HM, Hossfeld DK, Lawler SD, Mitelman F, Nilsson P. Pierre RV, Philip P, Prigogina E, Rowley JD, Sakurai M, Sandberg AA, Secker Walker LM, Tricot $G$, vandeBerghe $H$, Van Orshoven $A$, Vuopio $\mathbf{P}$, Whang-Pang J. Chromosomal abnormalities identify high-risk and low-risk patients with acute lymphoblastic leukemia. Blood 67:415, 1986

8. Kaplan HS. Hodgkin's disease. 2nd Edition. Cambridge, Massachusetts: Harvard University Press, 1980. p 52 .

9. Sandberg AA. The lymphomas In Sandberg AA The chromosomes in human cancer and leukemia. New York: Elsevier, 1980, p 378

10. Fukuhara S, Rowley JD. Chromosome 14 translocations in non-Burkitt lymphomas. Int. J Cancer $22 ; 14,1978$

11. Fleischmann J, Krizsa F. Chromosomes in malignant lymphoma (study on short term lymph node cultures). Haematologica 11:47, 1977

12. Reeves BR. Cytogenetics of malignant lymphomas. Studies using a Giemsa banding technique. Humangenetik 20:231, 1973

13. Reeves BR, Pickup VL. The chromosome changes in non-Burkitt lymphomas. Hum Genet $\$ 3: 349,1980$

14. Lawler SD, Swansbury GJ: Cytogenetic studies in Hodgkin's disease. In Selby P and McElwain TJ (eds) Hodgkin's disease. Oxford. Blackwell Scientific Publications, 1987, p 43

15. Slavutsky $I_{\text {in }}$ de Vinuesa ML, Estevez ME, Sen L, de Salum SB. Cytogenetic and immunologic phenotype findings in Hodgkin"s disease. Canc Genet Cytogenet 114:123, 1985

16. Cabanillas $F$, Pathak $S$, Trujillo $J$, Grant $G$, Cork $A$, Hagemeister FB, Velasquez WS, McLaughlin P, Redman J, Katz $R$, Butler JJ, Freireich EJ. Cytogenetic features of Hodgkin's disease suggest possible origin from a lymphocyte. Blood, $71: 1615,1988$

17. Bennet MH, MacLennan KA, Easterling MJ, Vaughan Hudson B, Vaughan Hudson G, Jelliffe AM. Analysis of histological subtypes in Hodgkin's disease in relation to prognosis and survival. In Quaglino D and Hayloe FGJ (Eds) The Cytobiology of leukaemias and lymphomas, Serona Symposia, vol 20, New York: Raven Press, 1985, p 15

18. Carbone PP, Kaplan HG, Musshoff $K$, Smithers DW, Tubiana M. Report of the committee on Hodgkin's disease staging cllassification. Cancer Res 31:1860, 1971

19. Kaye SB, Juttner CA, Smith IE, Barrett A, Austin DE Peckham MJ, McElwain TJ. Three years experience with ChIVPP (a combination of drugs of low toxicity) for the treatment of Hodgkin's disease. Brit J Cancer 39:168, 1978 
20. DeVita VT, Serpick AA, Carbone PP. Combination chemotherapy in the treatment of advanced Hodgkin's disease. Ann Intern Med 73:891, 1970

21. Bonadonna G, Valagussa P, Santoro A. Altemating non-cross-resistant combination chemotherapy or MOPP in stage IV Hodgkin's disease. Ann Intern Med 104:739, 1986

22. Sanger WG, Armitage JO, Bridge $J$, Weisenburger DD, Fordyce R, Purtilo DT. Initial and subsequent cytogenetic studies in malignant lymphoma. Cancer $140,3014,1987$

23. Hamden DG, Klinger HP, eds ISCN (1985). An intemational system for human cytogenetic nomenclature. Basel Karger. 1985, p 1

24. Rowley JD. Chromosomes in Hodgkin's disease. Cancer Treat Rep 66:639, 1982

25. Hansmann ML, Goddde-Salz E, Pak-Kwan Hui, MÜler-Hermelink H-K, Lennert K Cytogenetic findings in nodular paragranuloma (Hodgkin's disease with lymphocytic predominance nodular) and in progressively transformed germinal centers. Cancer Genet Cytogenet 21: 319, 1986

26. Sandberg AA. Synoptic wiew of specific chromosomal changes in human cancer ${ }_{\text {, leukemia, and }}$ gene loci. In Sandberg. AA The chromosomes in human cancer and leukemia. New York. Elsevier. 1981, p 566

27. Klein G, Klein E. Evolutions of tumours and the impact of nolecular oneology. Nature $315: 190$. 1985

28. Moeling $K$, Heimann $B_{n}$ Beimling $\mathbf{P}$, Rapp UR, Sander $T$. Serine and threonine specific protein kinase activities of purified gag-mil and gag-raf proteins. Nature 312.5581985

29. Hossfeld DK, Schmidt CG. Chromosome findings in effusions from patients with Hodgkin"s disease. Int J Cancer 21:147, 1978 
3

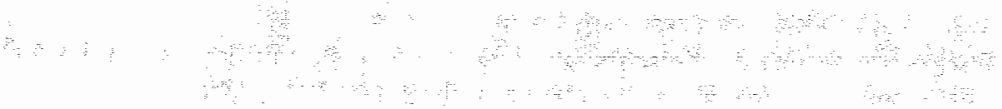

? : $\quad \therefore 4=$ 
CHAPTER 3

\section{Chromosomal abnormalities in untreated patients with non-Hodgkin's lymphoma:}

Associations with histology, clinical characteristics and treatment outcome

Harry C. Schouten, Warren G. Sanger, Dennis D. Weisenburger, James Anderson and James O. Armitage for the Nebraska Lymphoma Study Group Blood 1990, 75: 1841-1847 


\section{Y. Abstract}

We describe the chromosomal abnormalities found in 104 previously untreated patients with non-Hodgkin"s lymphoma (NHL) and the correlations of these abnormalities with disease characteristics. The cytogenetic method used was a 24 to 48 hours culture, followed by G-banding. Several significant associations were discovered. A trisomy 3 was correlated with high grade NHL. In the patients with an immunoblastic NHL an abnormal chromosome \#3 or \#6 was significantly more frequently found. As previously described a $t(14 ; 18)$ was significantly correlated with a follicular growth pattern. Abnormalities on chromosome \#17 were correlated with a diffuse histology and a shorter survival. A shorter survival was also correlated with $a+5,+6,+18$, all abnormalities on chromosome \#5 or involvement of breakpoint 14q11-12. In a multivariate analysis these chromosomal abnormalities appeared to be independent prognostic factors and correlated with survival more strongly than any "traditional" prognostic variable. Patients with a $t(11 ; 14)(q 13 ; q 32)$ had an elevated LDH. Skin infiltration was correlated with abnormalities on $2 p$. Abnormalities involving breakpoints 6q11-16 were correlated with B symptoms. Patients with abnormalities involving breakpoints $3 q 21-25$ and 13q21-24 had more frequent bulky disease. The correlations of certain clinical findings with specific chromosomal abnormalities might be of help in unveiling the pathogenetic mechanisms of NHL and tailoring treatment regimens.

Y Introduction

Early in this century Boveri hypothesized that all cells of malignant tumors had karyotypic abnormalities and that any event leading to chromosomal abnormalities would result in a malignant tumor (1). However, it took many decades before the Philadelphia chromosome in chronic myelogenous leukemia was described (2). Since then, cytogenetic abnormalities have been found in several diseases including acute leukemias $(3,4)$, myelodysplastic syndromes $(5)$, and non-Hodgkin's lymphomas (NHL) (6-25).

Several karyotypic abnormalities in NHL are associated with a particular histology, localization of disease or treatment outcome (6-25). However, many reports have included only small numbers of patients or patients analyzed at relapse. We analyzed 104 patients with cytogenetic abnormalities in newly diagnosed NHL that were treated according to Nebraska Lymphoma Study Group protocols. We describe the cytogenetic abnormalities found in these patients and correlate them with histology, clinical characteristics and response to therapy. 


\section{Y Materials and Methods}

\section{Patient Characteristics}

Between October 1982 and April 1988, the lymph nodes or other sites of disease of 123 patients with histologically-confirmed and previously untreated NHL were studied cytogenetically; in 10 patients the results were inconclusive, in nine patients they were normal and in 104 abnormal. Alll of the tissues examined were involved by lymphoma. A piece of the same tissue utilized for cytogenetic analysis was studied for histology and B-cell and T-cell markers, using an immunoperoxidase technique. The Working Formulation Classification was used (26). Staging consisted of a complete history and physical examination, chest radiograph, computed tomography scan of the abdomen, and bone marrow biopsy. The patients were staged according to the Ann Arbor system (27).

In all patients, the tumor was studied at the time of primary diagnosis. No selection criteria other than the availability of cytogenetic data the time of diagnosis and treatment according to Nebraska Lymphoma Study Group protocols was used. No patients with a HIV related lymphoma were included.

The clinical characteristics of the patients with abnormal cytogenetic analysis are listed in Table I. Similar data from the patients with the normal chromosome studies are also listed in Table I for comparison. The patients with the inconclusive results were excluded from analysis. The follow up of the patients was 1-55 months (median, 16 months).

\section{Treatment}

The patients were treated according to protocols of the Nebraska Lymphoma Study Group. Patients with pathologically-confirmed stage I disease were treated with radiation therapy until 1986 and more recently with radiation following two or three cycles of chemotherapy. The patients with stage II, III and IV disease were all treated with chemotherapy, directly after the diagnosis was made. The chemotherapy regimens consisted of CAP-BOP (cyclophosphamide, adriamycin, procarbazine, bleomycin, vincristine, and dexamethasone) (28) for the intermediate and high grade malignant lymphomas or ChlVP (chllorambucil $12 \mathrm{mg} / \mathrm{m}^{2}$ (maximal dose 20mg) p.o. days $1-5$, vincristine $1 \mathrm{mg} / \mathrm{m}^{2}$ i.v. day 1 and prednisone $100 \mathrm{mg}$ p.o. days $1-5$, every $3-4$ weeks) for the lymphomas of low grade malignancy.

A complete remission (CR) was defined as the absence of clinically demonstrable disease after the completion of the initial therapy and restaging. Disease-free survival was defined as the time period from CR until rellapse, death or time of last follow-up. 
Table I. Characteristics of patients with an normal or abnormal study

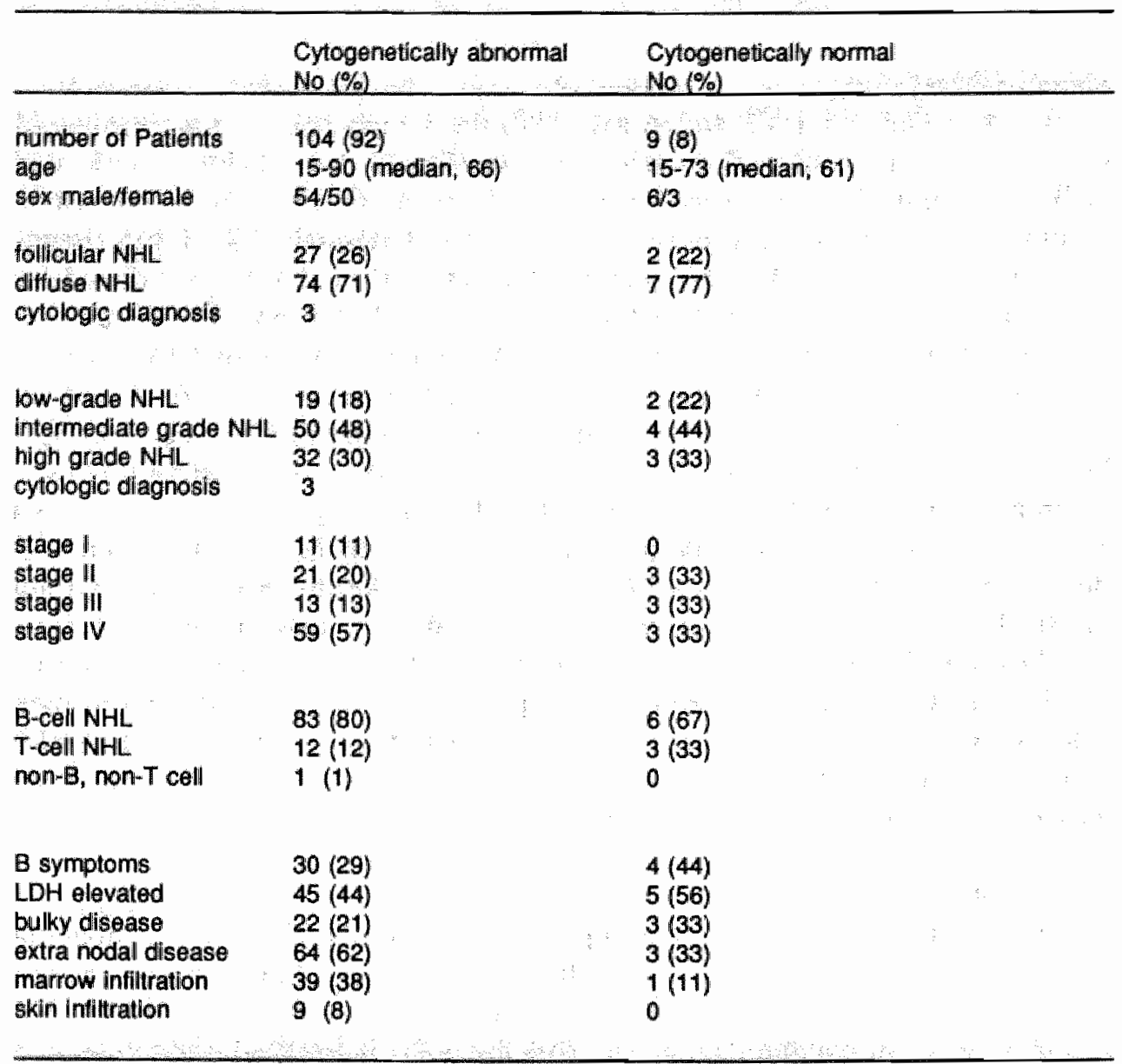

Cytogenetic Methods

The methods of culturing and processing of the lymph nodes are described elsewhere (20). In short, after mechanically mincing the tissue in RPMI 1640 (Gibco, Grand Island, NY) including $20 \%$ fetal bovine serum and antibiotics the cell suspensions were incubated at $37.5^{\circ} \mathrm{C}$ and cultured for 24 and 48 hours without the use of mitogens. After the exposure to Colcemid $(0.05 \mathrm{ug} / \mathrm{ml})$ (Gibco, Grand Island, NY), the preparations were resuspended in 0.074 molar KCL for 10 minutes and fixed with a 3:1 mixture of methanol and glacial acetic acid. After repeating the fixation process three times, the slide preparations were made, aged overnight at $60^{\circ} \mathrm{C}$ and G-banded with Wright's stain. All metaphase plates were microscopically analyzed, recorded, and photographed. An abnormal 
clone was defined as two or more cells with the same structural abnormality or the same extra chromosome, or the presence of three or more cells with the same missing chromosome. If only one mitotic cell with an abnormal karyotype was present it was considered a malignant clone if there was structural abnormality known to be associated with lymphoma (i.e. in two cases). Normal cells were considered to be present if a single cytogenetically normal cell was seen. If these criteria were not fulfilled or less than 5 normal mitotic cells were present or the results were too poor to analyze, the test was classified as inconclusive and excluded from analysis. The karyotypes were designated according to the classification of the International System for Human Cytogenetic Nomenclature (ISCN 1985) (29).

Study Design and Statistical Methods

All chromosomal abnormalities occurring in more than $5 \%$ of the patients were correlated with parameters as age, sex, histology, growth pattern, stage of disease, B symptoms, LDH, bulky disease, B/T-cell phenotype, extranodal disease, marrow involvement, skin infiltration and response to therapy. The Chi Square test, with the Yates correction when appropriate, was used to assess significance levels from the analysis of 2 -way tables (30). The log-rank test was used to evaluate differences in the distributions of "times to event" (31). Statistically significant refers to those comparisons that yielded a significance level of $\mathrm{p} \leq 0.01$. A multivariate analysis of survival using the proportional hazards model of Cox was conducted to assess the independent prognostic influence of the various patient characteristics on survival (32). In an attempt to produce patient subgroups of differing prognosis, recursive partitioning of the available patient population was performed. This process involves the partitioning of the population onto two groups, initially based on that characteristic which produces subgroups most different in terms of their survival experience. This process is then repeated on the subsets producing a regression tree. 
Table II. Distribution of defined chromosomal abnormalities occurring in at least $5 \%$ of the patients over the histologic subgroups.

Histologic Type(1)

Abnor- A B C D E F G H J Far (2) Diftuse grade grade grade $\begin{array}{llllllllllllllll}\text { mality total } & 3 & 1 & 11 & 11 & 11 & 5 & 23 & 24 & 5 & 3 & 27 & 74 & 19 & 50 & 32\end{array}$

$\begin{array}{lllllllllllllllll}-1 & 5 & 0 & 0 & 1 & 0 & 0 & 1 & 0 & 2 & 1 & 0 & 1 & 4 & 1 & 1\end{array}$

$\begin{array}{llllllllllllllllllll}+2 & 5 & 0 & 0 & 0 & 2 & 0 & 0 & 0 & 2 & 1 & 0 & 3 & 3 & 0 & 2 & 3\end{array}$

$\begin{array}{lllllllllllllllllll}+3 & 16 & 1 & 0 & 1 & 1 & 0 & 0 & 3 & 8 & 0 & 3 & 13 & 3 & 4 & 9\end{array}$

$\begin{array}{llllllllllllllllll}+5 & 11 & 0 & 0 & 0 & 2 & 0 & 0 & 2 & 5 & 1 & 0 & 3 & 8 & 1 & 4 & 6\end{array}$

$\begin{array}{lllllllllllllllll}+6 & 6 & 0 & 0 & 0 & 1 & 0 & 0 & 0 & 4 & 0 & 0 & 1 & 5 & 1 & 1 & 4 \\ -6 & 5 & 0 & 0 & 0 & 0 & 0 & 1 & 1 & 2 & 0 & 0 & 1 & 4 & 1 & 2 & 2\end{array}$

$\begin{array}{lllllllllllllllll}47 & 14 & 0 & 0 & 3 & 4 & 0 & 0 & 3 & 4 & 0 & 0 & 7 & 7 & 3 & 7 & 4\end{array}$

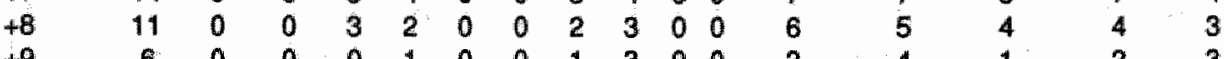

$\begin{array}{rlllllllllllllllll}+9 & 6 & 0 & 0 & 0 & 1 & 0 & 0 & 1 & 3 & 0 & 0 & 2 & 4 & 1 & 2 & 3\end{array}$

$\begin{array}{llllllllllllllllll}+11 & 16 & 0 & 0 & 0 & 4 & 0 & 0 & 3 & 8 & 0 & 0 & 5 & 11 & 1 & 7 & 8\end{array}$

$\begin{array}{lllllllllllllllll}1(11 ; 4) & 5 & 0 & 0 & 1 & 0 & 2 & 0 & 1 & 0 & 1 & 0 & 1 & 4 & 1 & 3 & 1\end{array}$

q $13 ; 932$

$+12$

$\begin{array}{lcccccccccccccccc}t(14 ; 18) & 27 & 0 & 1 & 5 & 5 & 0 & 0 & 9 & 5 & 0 & 0 & 13 & 14 & 8 & 14 & 5 \\ +15 & 5 & 0 & 0 & 0 & 1 & 0 & 0 & 1 & 2 & 0 & 0 & 2 & 3 & 1 & 2 & 2\end{array}$

$\begin{array}{lllllllllllllllll}+16 & 6 & 0 & 0 & 0 & 1 & 0 & 0 & 1 & 2 & 0 & 0 & 3 & 3 & 2 & 2 & 2\end{array}$

$\begin{array}{lllllllllllllllll}+17 & 7 & 0 & 0 & 0 & 1 & 0 & 0 & 4 & 2 & 0 & 0 & 1 & 6 & 0 & 5 & 2\end{array}$

$\begin{array}{lllllllllllllllll}+18 & 20 & 1 & 1 & 1 & 1 & 0 & 0 & 6 & 9 & 0 & 0 & 4 & 16 & 4 & 7 & 9\end{array}$

$\begin{array}{lllllllllllllllll}+19 & 9 & 0 & 0 & 0 & 2 & 0 & 0 & 3 & 3 & 0 & 0 & 4 & 5 & 1 & 5 & 3\end{array}$

$\begin{array}{lllllllllllllllll}+20 & 10 & 0 & 0 & 1 & 2 & 0 & 0 & 2 & 4 & 0 & 0 & 4 & 6 & 2 & 4 & 4\end{array}$

$\begin{array}{lccccccccccccccccc}* 21 & 9 & 0 & 0 & 0 & 3 & 0 & 0 & 2 & 3 & 0 & 0 & 4 & 5 & 1 & 5 & 3\end{array}$

$\begin{array}{llllllllllllllllll}+22 & 12 & 0 & 0 & 1 & 3 & 0 & 1 & 1 & 5 & 0 & 0 & 5 & 7 & 2 & 5 & 5\end{array}$

1 - According to Wonking Formulation (26)

Abbrovialions:
A - small tymphocytic type
F - diffuse mixed cell type
B - tollicular small cleaved cell type
C - follocular mixed cell type
G - diffuse large cell type
D - follicular large cell type
H - immunoblastic type
E- diffuse small cleaved cell type
1 - Hymphoblastic type
J - small non-cleaved cell type

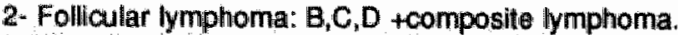


TABLE III. Statistically significant correlations between circumscript or combinations of chromosomal abnormalities occurring in more than $5 \%$ of the patients and characteristics of disease

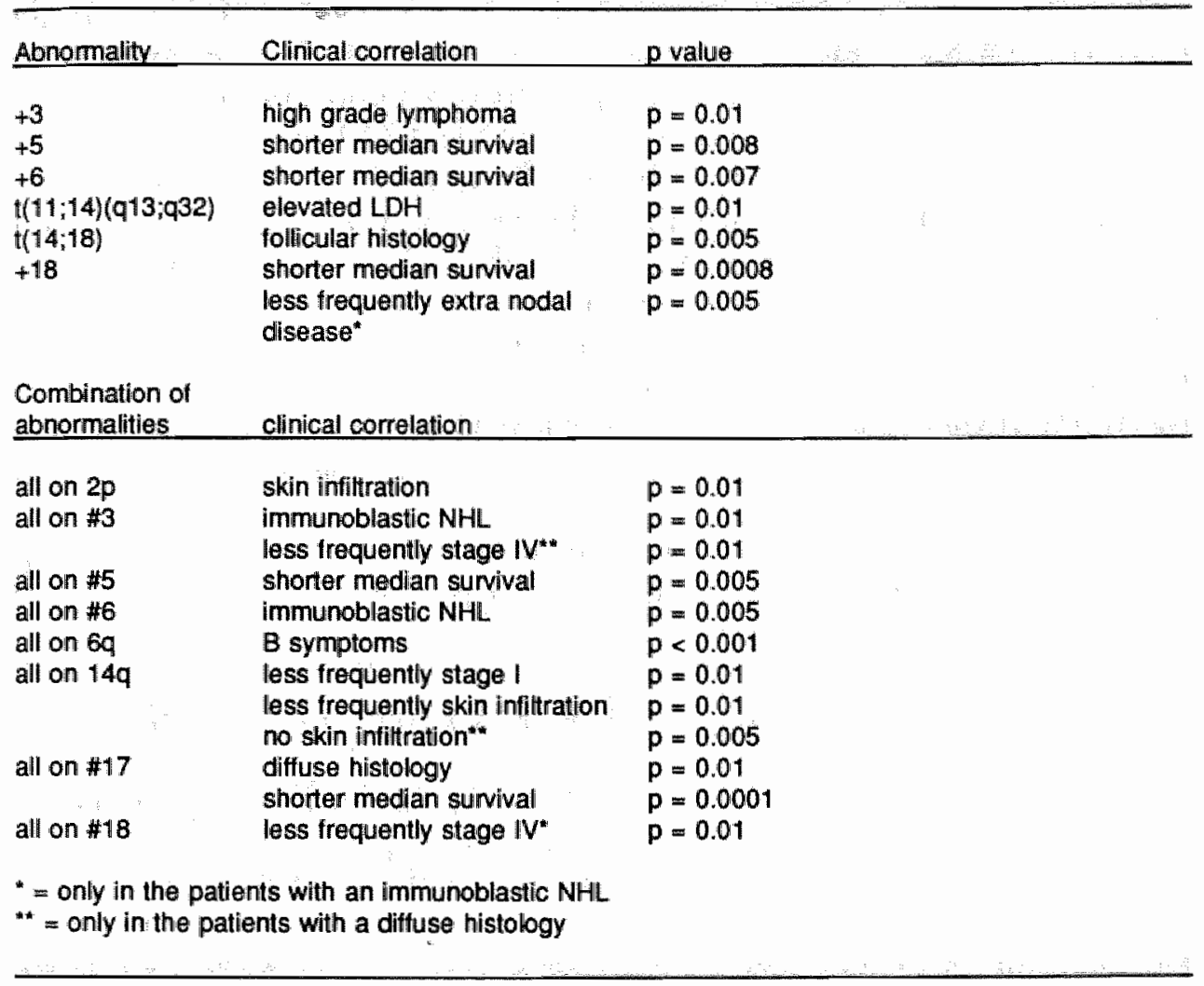

Y Results

Relationships Between Chromosomal Abnormalities And Histologic Type (Tables II and II)

Several monosomies, trisomies, and translocations occurring in at least $5 \%$ of the patients were found. A monosomy $1, a-6$ and a $t(11 ; 14)(q 13 ; q 32)$ had no obvious relation with a histologic type. A trisomy 17 occurred more frequently in the intermediate grade histologies. The trisomies of chromosomes \#2, 12, 15, 19,20 and 21 were not clearly associated with a particular histologic type. A $\mathrm{t}(14 ; 18)$ was observed in about $50 \%$ of patients with a follicular and $20 \%$ of patients with diffuse lymphoma.

In the following histologic subgroups significant correlations between chromosomal abnormalities and histology were observed. 
Immunoblastic NHL: Twelve of the 24 patients had an abnormality of chromosome \#3. This correlation is significant $(\mathrm{p}=0.01)$. Of these 12 patients, eight had a trisomy 3 and two had a breakpoint involving 3q21-25. Fourteen patients had an abnormal chromosome \#6. This correlation was significant $(p=0.005)$. Of these 14 patients, four had a trisomy 6 , four an abnormality involving breakpoint $6 \mathrm{q} 11-16$ and three patients an abnormality located on $6 \mathrm{q} 21$ 24 . The other patients with an abnormal chromosome \#6 had a variety of abnormalities, including two patients with a -6 . Thirteen of the 24 patients with an immunoblastic NHL had an abnormal chromosome \#18 of whom five had a $t(14 ; 18)$ and nine patients $a+18$. $A+5(n=5),+6(n=4),+9(n=3),+11(n=8)$ and $+22(n=5)$ occurred frequently in patients with immunoblastic NHL.

Follicular histology: 17 of the 27 patients had an abnormality involving breakpoint $14 \mathrm{q} 32$ of whom 13 were a $t(14 ; 18)$. This was a significant correlation $(p=0.005)$. However, it should be stressed that 10 patients had no $t(14 ; 18)$ or a breakpoint at $14 \mathrm{q} 32$ detected. $\mathrm{A}+7,+8$ and +16 also occurred frequently in patients with a follicular NHL.

Diffuse histology: 36 out of 74 patients had an abnormal long arm of chromosome 14; in 25 patients involving breakpoint $14 \mathrm{q} 32$ and in 5 other patients breakpoint $14 \mathrm{q} 11-12$.

Correlation Between Chromosomal Abnormalities And Disease Characteristics (Tables III and IV)

Chromosome \#1: Breakpoints at $1 \mathrm{q} 21-25(\mathrm{n}=9)$ appeared to be significantly correlated with the absence of marrow involvement $(p=0.005)$.

Chromosome \#2: No specific breakpoints on this chromosome occurring in at least $5 \%$ of the patients were recognized. However, all abnormalities involving the short arm of chromosome $\$ 2(n=5)$ were correllated with skin infiltration $(\mathrm{p}=0.01)$.

Chromosome \#3: Breakpoints 3q21-25 ( $n=6$ ) were correlated with the presence of bulky disease $(p=0.005)$. A trisomy of chromosome $\# 3(n=16)$ was correlated with high-grade histology $(\mathrm{p}=0.01)$. Twenty-two patients had a diffuse histology and an abnormality involving chromosome \#3. These patients had a lower frequency of stage IV disease $(\mathrm{p}=0.01)$.

Chromosome \#5: No specific breakpoints occurring in at least $5 \%$ of the patients were recognized. Patients with a $+5(n=12)$ had a shorter median survival ( 6 vs. 36 months) $(p=0.008)$, as did all patients $(n=16)$ with an abnormality involving this chromosome $(p=0.005)$.

Chromosome \#6: Seven patients had a breakpoint localized at area $6 q 11-16$ and they had a higher incidence of B-symptoms ( $p<0.001$ ). Also, all patients with abnormalities on $6 \mathrm{q}$ combined $(\mathrm{n}=15)$ had a higher incidence of $\mathrm{B}$-symptoms $(p<0.001)$. Patients with $a+6(n=6)$ had a median survival of 8 months vs. 36 
TABLE IV. Statistically significant correlations between breakpoints occurring in more than $5 \%$ of the patients and characteristics of disease

\begin{tabular}{lll}
\hline Breakpoint (cluster) & Clinical Correlations & $p$ value \\
\hline $1 q 21-25$ & no marrow involvement & $p=0.005$ \\
$3 q 21-25$ & bulky disease & $p=0.005$ \\
$6 q 11-16$ & B symptoms & $p<0.001$ \\
$11 q 13$ & elevated LDH & $p=0.01$ \\
$11 q 23-24$ & B-cell & $p=0.01$ \\
$13 q 21-24$ & bulky disease & $p=0.001$ \\
$14 q 11-12$ & shorter median sunvival & $p<0.001$ \\
$14 q 32$ & follicular histology & $p=0.01$ \\
$18 q 21$ & tollicular histology & $p=0.005$ \\
\hline
\end{tabular}

months $(\mathrm{p}=0.007)$ for all patients with a chromosomal abnormality.

Chromosome \#11: Abnormalities of breakpoint 11q13 were found in five patients, always as a part of a $t(11 ; 14)(q 13 ; q 32)$. This abnormality was correlated with a higher frequency of LDH elevation ( $p=0.01$ ) without a correlation with other parameters for tumor load. Five other patients had a breakpoint at 11q23-24. This abnormality was related with a B-cell phenotype $(p=0.01)$.

Chromosome \#13: Five patients had an abnormality involving breakpoint 13q21-24. They were more likely to have bulky disease $(p=0.001)$.

Chromosome \#14: Five patients had a breakpoint involving 14q11-12 and they had a significantly shorter median survivall ( 8 months vs. 36 months; $p=0.001$ ). Only one of these patients had a T-cell phenotype. Forty three patients had a breakpoint at $14 \mathrm{q} 32$. They were more likely to have a follicular growth pattern $(p=0.01)$, but there was no relation with survival or disease-free survival. of these 43 patients with a breakpoint at $14 q 32,26$ had a $t(14 ; 18)$ and they were more likely to have a follicular growth pattern $(\mathrm{p}=0.005)$, but there was no correlation with survival or disease-free survival. Fifty four patients had an abnormality in chromosome \#14q. These patients were less likely to have stage I disease $(\mathrm{p}=0.01)$ or skin infiltration $(\mathrm{p}=0.01)$. In the patients with a diffuse histology, the abnormalities on chromosome $14 \mathrm{q}$ combined were correlated with the absence of skin infiltration $(p=0.005)$. This correlation was not present for breakpoints $14 \mathrm{q} 11-12$ or $14 \mathrm{q} 32$. 
Chromosome \#17: No specific breakpoints involving at least $5 \%$ of the patients were recognized. All patients with an abnormal chromosome \#17 combined $(n=20)$ had a higher frequency of diffuse pathology $(p=0.01)$ and a shorter median survival ( 7 months ws. 42 months, $p<0.0001$ ) compared with the patients without this abnormality.

Chromosome \#18: Twenty-six patients had a breakpoint at $18 \mathrm{q} 21$, all as a part of a $t(14 ; 18)$. For correlations see Chromosome \#14 section. A trisomy 18 $(n=20)$ was correlated with a shorter median survival of 6 months vs. 41 months $(p=0.008)$ for all other patients. The presence of an abnormal chromosome \#18 in the patients with an immunoblastic NHL was correlated with a lower frequency of stage IV disease $(\mathrm{p}=0.01$ ). In the same histologic subgroup $a+18$ was correlated with a lower frequency of extranodal disease $(p=0.005)$.

For all other chromosomes the number of patients with an abnormality was less than $5 \%$ or there was no significant correlation with the tested disease characteristics.

\section{The Importance Of Normal Metaphases}

In 58 patients only abnormal karyotypes were found, while in 46 patients there was an admixture of normal cells. There was no significant correlation between the presence or absence of normal cells and histologic type. Also, there was no difference in survival between the patients with only abnormal karyotypes and those with an admixture of normal karyotypes and those with only normal karyotypes. This was also the case in subgroups as follicular, diffuse, low grade or intermediate and high grade NHL.

TABLE V. Multivariate Analysis of Prognostic Factors of Importance for Survival

\begin{tabular}{lll}
\hline Characteristic & Relative Risk & p-value \\
\hline LDH $>1.5$ high normal & 2.40 & 0.01 \\
B symploms & 2.87 & 0.004 \\
Stage IV & 2.78 & 0.006 \\
age $>70$ & 3.33 & 0.0008 \\
chromosomal abnormalities & 5.49 & 0.0000007 \\
\hline
\end{tabular}




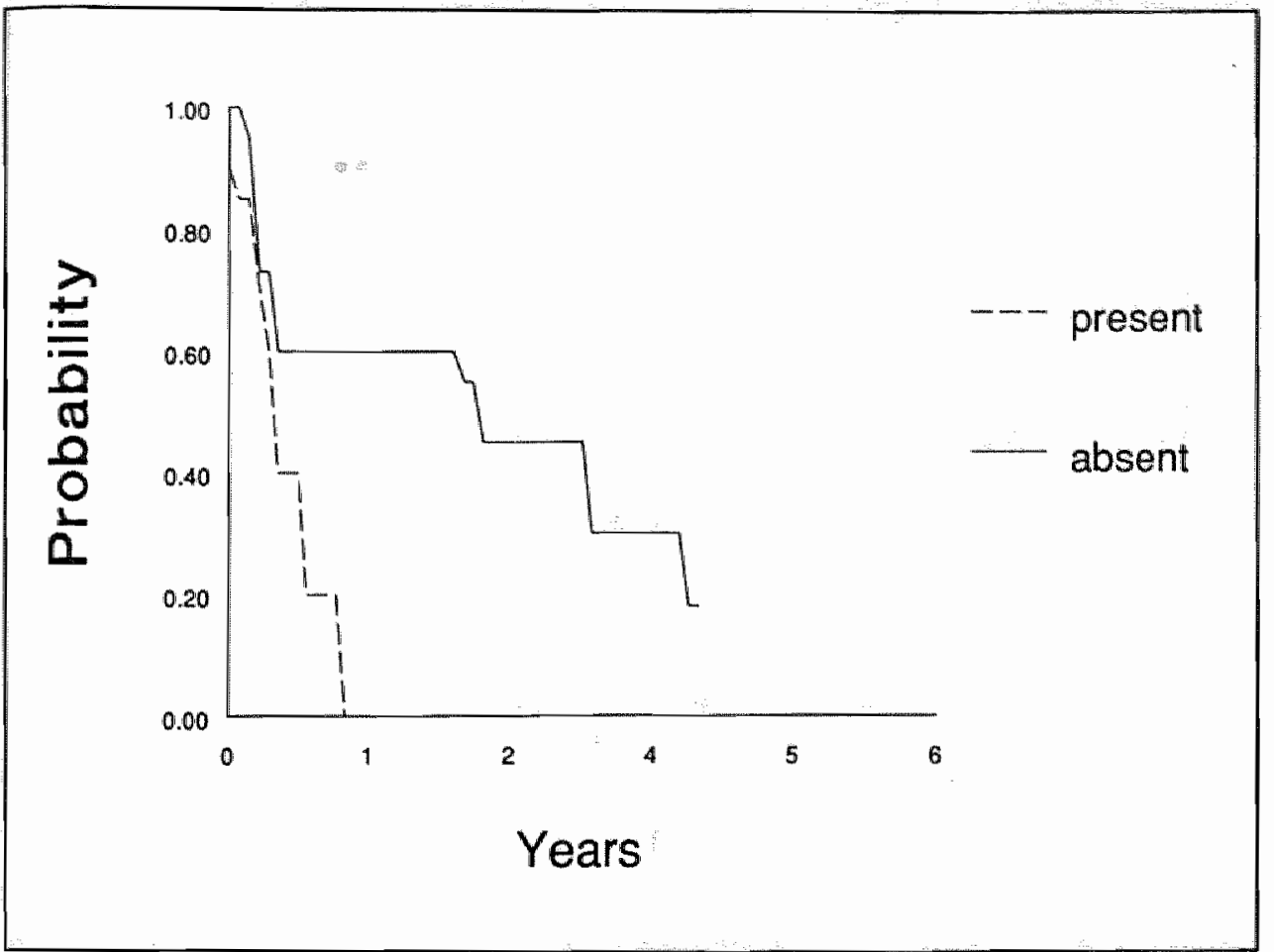

Figure 1. The influence on survival for the presence or absence of one of the chromosomal abnormalities that were correlated with survival is shown for the patients with $B$ symptoms. The difference is significant $(p=0.004)$.

\section{Multivariate analysis}

A multivariate analysis of survival using the proportional hazards model of Cox was conducted to assess the independent prognostic influence of the various patient characteristics on survival. Four patient characteristics were significantly associated with patient survival (i.e. LDH $>1.5$ high normal, B symptoms, stage IV disease and age $>70$ ) (see Table V). After adjustment for these variables, neither gender, bulky disease, nor histology were significantly associated with survival. The abnormalities that were correlated with survival $(+5,+6,+18$, all on \#5, all on \#17 and breakpoints 14q11-12) were then analyzed to assess the prognostic significance (see Table V). The presence of these cytogenetic abnormalities is an indication of a significant poorer survival $(\mathrm{p}=0.0000007)$, even after adjusting for other features of considerable prognostic importance. The number of patients with any specific chromosomal abnormality was too small to allow for the assessment of the individual cytogenetic abnormalities prognostic significance. 


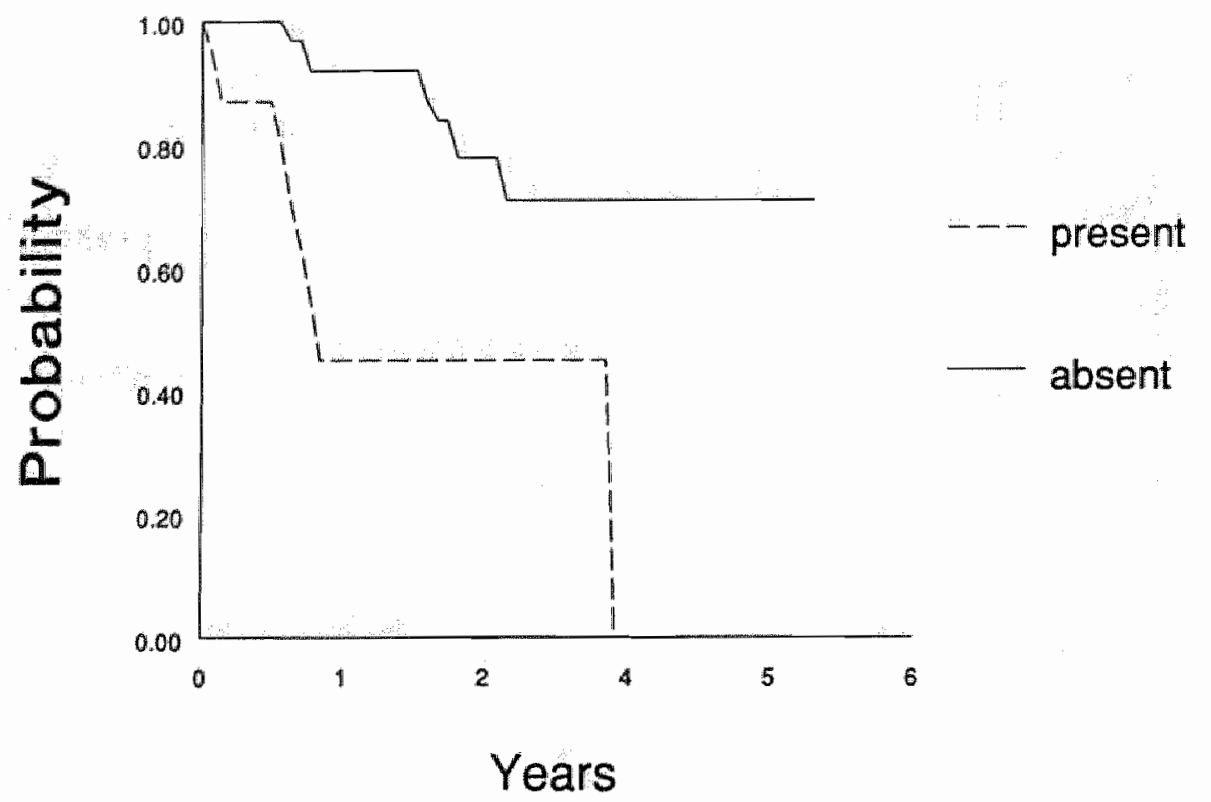

Figure 2. The influence on survival for the presence or absence of one of the chromosomal abnormalities that were correlated with survival is shown for the patients with no $B$ symptoms and low $L D H$. The difference is significant $(p=0.0008)$

\section{Recursive partitioning}

Based on variables most prognostic for survival (presence of B symptoms and $\mathrm{LDH}$ ) the prognostic influence of the presence of one of the six cytogenetic abnormalities correlated with survival $(+5,+6,+18$, all on $\# 5$, all on $\# 17$ and breakpoints 14q11-12) was then assessed within each of the three prognostic subgroups. The presence of one of these six chromosomal abnormalities was significantly associated with survival in all three prognostic subgroups (Figure 1-3).

\section{Discussion}

In 104 of $123(84.6 \%)$ patients with proven and previously untreated NHL, the karyotypes showed one or more abnormalities. This yield of abnormal metaphases is comparable with previous studies $(11,13,16)$. However, in contrast 


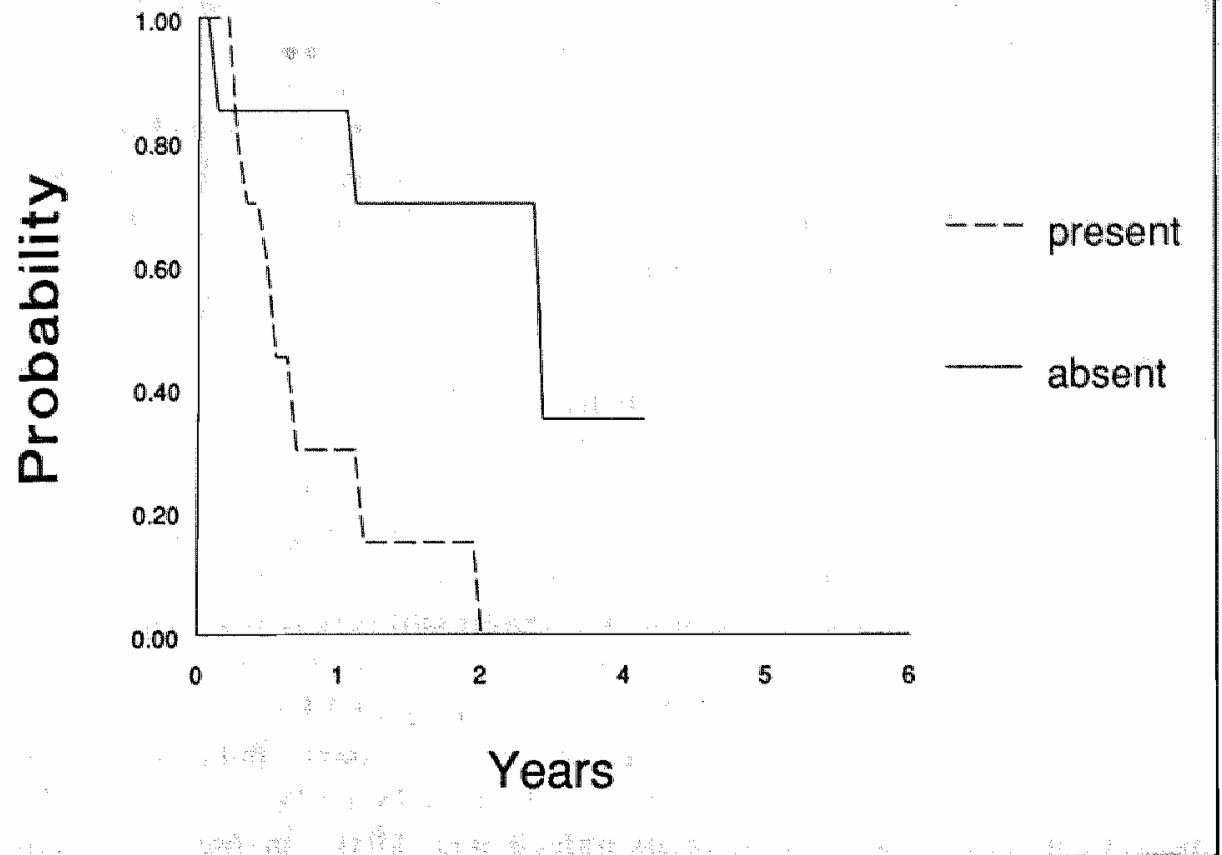

Figure 3. The influence on survival for the presence or absence of one of the chromosomal abnormalities that were correlated with sumival is shown for the patients with no $B$ symptoms and high LDH. The difference is significant $(p=0.03)$.

to others $(10,13,22,23)$, we did not find any difference for survival or disease-free survival between patients that had only normal karyotypes, only abnonnal karyotypes or a mixture. Also, in contrast with others (13) in the subgroup of the follicular NHL there was no difference in outcome between patients with only abnomal karyotypes and patients with an admixture of normal cells.

Cytogenetic findings in lymphomas might be helpful in unveiling the pathogenesis of these disorders. Several of the breakpoints we and others have found correlate with the presence of known oncogenes. The fact that there are breakpoints that correlate with disease characteristics, but not with known oncogenes, could suggest the presence of new, yet undiscovered, regulatory genes on these chromosomes. Also of potential importance are several correlations with disease characteristics found for combinations of abnormalities involving arms or complete chromosomes, that were not present for specific breakpoints. This suggests that in larger series a significant correlation with disease parameters for a more defined breakpoint might be found. Another 
possibility is that structural changes on that chromosome related with a particular disease phenomenon are not in every patient located on the same place on the chromosome, or that different changes on that particular chromosome can cause the same manifestation of the disease.

Several chromosomal abnormalities had a strong correlation with disease characteristics (Table III). A trisomy 3 was significantly correlated with a high grade histology. Yunis (7) found that a +3 was almost exclusively present in follicular large cell NHL, however, in our series only one of 16 patients had this type and eight had the immunoblastic type. The Fifth Workshop (15) found a +3 predominantly among diffuse mixed lymphomas. In our series $25 \%$ of the patients with a +3 had this histologic subtype. Recently, a correlation between dup $3 \mathrm{p}$ or $\mathrm{a}+3$ with a good prognosis in large cell NHL was reported (24). We did not observe a survival advantage for these patients. Correlations between a trisomy of chromosome \#5, \#6, \#18, all abnormalities on \#5, the breakpoints 14q11-12 and shorter survival found in a multivariate analysis to be independent of the usual clinical prognostic factors, have not been previously reported. Yunis (7) found an association for one of these abnormalities $(+18)$ with the follicular large cell type. The correlations between a $t(11 ; 14)(\mathrm{q} 13 ; \mathrm{q} 32)$ and also for breakpoint 11q13 and elevated LDH was not suggested before and was in our series not related with tumor load, as reflected by stage, bulky disease or B symptoms. Several authors (16-18) described a correlation between a $t(8 ; 14)$ and high grade, more specifically small non-cleaved NHL. In our series only 2 patients had a $t(8 ; 14)$, but they both had a small non-cleaved NHL. In contrast to Yunis (24) patients with a dup 2 p or a +2 and large cell NHL had no significantly different treatment outcome compared with the other patients.

Analyzing the breakpoints of the chromosomes regardless of the cytogenetic abnormality, we found several significant correlations (table IV). Breakpoints $14 \mathrm{q} 32$ and $18 \mathrm{q} 21$ were correlated with a follicular histology. The breakpoints 11q23-24 were correlated with a B-cell phenotype. Bulky disease was correlated with breakpoints 3q21-25 and 13q21-24. Also, B symptoms were correlated with breakpoints $6 \mathrm{q} 11-16$. Patients with breakpoints $1 \mathrm{q} 21-25$ were less likely to have marrow involvement. Patients with breakpoints at 14q11-12 had a poorer treatment result. Because the location of the alpha gene T-cell receptor on $14 \mathrm{q} 11-13$ and the poorer outcome in patients with a T-cell lymphoma, this would not be of a surprise, however only one out of the five patients with this breakpoint had a T-cell NHL. Breakpoint $6 \mathrm{q} 21-25$ was in other studies present in the majority of patients with large cell histology $(16,18)$, however, only in $33 \%$ of our patients with large cell NHL. Also this breakpoint was reported to be correlated with bone marrow involvement (21), however, this could not be confirmed by our results. In a recent study several other correlations between chromosomal abnormalities and extranodal localizations of disease including 
sites of relapse were described as 1p32-36 and marrow infiltration, chromosone \#14 abnormalities and spleen infiltration, chromosome \#9 and lung localization, or monosomy 11 and bone localizations (21). These observations were not confirmed in this study, probably because the sites of relapse were not included in our analysis.

In combining all abnormalities on one arm, or all the abnormalities on one chromosome, we found several significant correlations. Patients with an abnormal $2 p$ had more skin involvement. All patients with an abnormal chromosome \#5 combined were found to have a shorter survival as was also detected for patients with $\mathrm{a}+5$. All patients with an abnormal chromosome $6 \mathrm{q}$ combined had a significant correlation with B symptoms, also found for breakpoints $6 \mathrm{q} 11-16$. The patients with abnormal chromosome \#14 or $14 \mathrm{q}$ combined, showed a correlation with the absence of skin infiltration and less frequently stage I disease. This correlation was not found for any specific abnormality involving chromosome \#14. Levine (13), Cabanillas (25), and our study observed that patients with an abnormal chromosome \#17 less often reached a CR and had a shorter survival. However, Cabanillas results were limited to the -17 and isochromosome $17 q$ (25). In addition, we found a correlation with a diffuse histology. Both correlations were also found for $17 \mathrm{p}$. In combining all abnormalities on the short arm of chromosome \#1, the Fifth Workshop (15) found a significant correlation with a T-cell phenotype. In our series only two out of nine patients with this abnormality had a T-cell phenotype.

Interestingly, of the 27 patients with a follicular lymphoma only 13 had a $t(14 ; 18)$ and 14 other patients with a $t(14 ; 18)$ had a diffuse histology. Although there is a significant correlation in our study between a $t(14 ; 18)$ and follicular growth pattern, this correlation is reported to be very strong for the patients with follicular small-cleaved NHL $(7,16)$. In our study only one patient had a follicular small-cleaved NHL, which might explain the lower frequency than expected.

We were able to demonstrate several new correlations between chromosome abnormalities and disease characteristics. Also, we observed that the chromosomal abnormalities that were correlated with survival were independent risk factors in a multivariate analysis. This can be explained by the large number of patients studied and the fact that the analysis was done at diagnosis excluding secondary abnormalities, induced by disease evolution or treatment. This is also a possible explanation for the fact that we could not confirm all the abnormalities found by others. Clearly, further studies should be done. With the addition of molecular biologic studies these data might be of importance in explaining and unveiling more of the pathobiology of malignant lymphoma. Also the prognostic factors related with survival might be of help in designing new treatment strategies. 


\section{References}

1. Boveri T. Zur Frage der Entstehung maligner Tumoren. Jena Gustaw Fischer. pp 1, 1914

2. Nowell PC Hungerford DA A minute chromosome in human chronic granulocytic leukemia. Science 132:1497, 1960 (letter)

3. Rowley $\mathrm{D}$, Alimena $\mathrm{G}$, Garson $\mathrm{OM}$, Hagemeyer $\mathrm{A}$, Mitelman $\mathrm{F}$, Prigogina $\mathrm{EL}$, A collaborative study of the relationship of the morphological type of acute non-lymphocytic leukemia with patient age and karyotype. Blood $59: 1013,1982$

4. Bloomfield CD, Goldman A, Alimena G, Berger R, Borgstrom GH, Brandt L, Catowsky D, delachapelle A, Dewald GW, Garsop OM, Garwics S, Golomb HM, Hossfeld DK, Lawler SD, Miteliman F, Nilsison P, Plerre RV, Philip P, Prigogina E, Rowley JD, Sakurai M, Sandberg AA, Secker Walker $\mathbf{L M}$, Tricot $\mathbf{G}$, vandeBerghe $\mathrm{H}$, Van Orshoven $\mathrm{A}$, Vuopio $\mathbf{P}$, Whang-Pang $J$. Chromosomal abnormalities identify high-risk and low-risk patients with acute lymphoblastic leukemia. Blood $67: 415,1986$

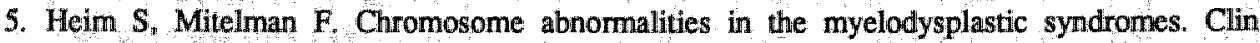
Haematol 15:1003, 1986

6. Han T, Sadamori N, Ozer $H$, Gajera $\mathbb{R}$, Gomez GA, Henderson ES, Bhargava A, Fitzpatrick $J_{\text {, }}$ Minowada J, Bloom ML. Sandberg AA. Cytogenetic studies in 77 patients with chronic lymphocytic leukemia: Correlations with clinical, immunologic, and phenotypic data. I Clin Oncol 2:1121, 1984

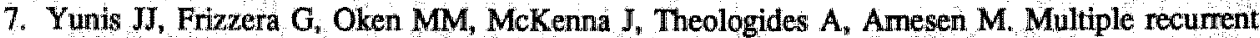
genomic defects in follicullar lymphoma. A possible model for cancer. N Engl J Med 316:79, 1987

8. Julliusson G. Immunologic and cytogenetic studies improve prognosis prediction in chronic Blymphocytic leukemia: A multivariate analysis of 24 variables. Cancer 58:688, 1986

9. Kaneko Y, Abe R, Sampi K, Sakuarai M, An analysis of chromosome findings in non-Hodgkin's lymphomas. Cancer Genet Cytogenet 5:107, 1982

10. Kristoffersson U, Heim $\mathbf{S}$, Mandahl $\mathbf{N}$, Olsson $\mathbf{H}$, Ranstam J, Akerman $M$, Mitelman $\mathbf{F}$. Prognostic implication of cytogenetic findings in 106 patients with non-Hodgkin"s lymphoma. Cancer Genet Cytogenet 25:55, 1987

11. Kaneko Y, Rowley JD, Variakojis D, Haren JM, Ueshima Y, Dally K, Kluskens LF. Prognostic implications of karyotype and morphology in patients with non-Hodgkin"s lymphoma. Int I Cancer 32:683, 1983

12. Juliusson $G$, Robert KH, Ost $A$, Friberg $K$, Biberfeld $P$, Nilsson $B$, Zech $L$, Gahrton $G$. Prognostic information from cytogenetic analysis in chronic B-lymphocytic leukemia and leukemic immunocytoma. Blood $65: 134,1985$

13. Levine EG, Arthur DC, Frizzera G, Peterson BA, Hurd DD, Bloomfield CD. Cytogenetic abnormalities predict clinical outcome in non-Hodgkin lymphoma. Ann Intem Med 108:14, 1988

14. Levine EG, Arthur DC, Gajl-Peczalska KJ, LeBien TW, Peterson BA, Hurd DD, Bloomfield CD. Correlations between immunological phenotype and karyotype in malignant lymphoma. Cancer Res 46:6481, 1986

15. Fifth International Workshop on Chromosomes in Leukemia-Lymphoma Correlation of chromosome abnomalities with histologic and immunologic characteristics in non-Hodgkin's lymphoma and adult T cell leukemia-lymphoma. Blood 70:1554, 1987

16. Levine EG, Arthur DC, Frizzera $G$, Peterson BA, Hurd DD, Bloomfield $C D$. There are differences in cytogenetic abnomalities among histologic subtypes of the non-Hodgkin's lymphomas. Blood $66: 1414,1985$ 
17. Koduru PRK. Fillippa DA, Richardson ME, Jhanwar SC, Chaganti SR, Koziner B, Clarkson BD, Lieberman $\mathrm{PH}_{y}$ Chaganti RSK. Cytogenetic and histologic correlations in malignant lymphomai. Blood 69:97, 1987

18: Bloomfield CD, Arthut DC, Frizzera $G$, Levine BG, Peterson BA, Gajl-Peczalska KJ. Nonrandom chromosome abnomalities in lymphoma. Cancer Res $43: 2975,1983$

19. Speaks SL, Sanger WG, Linder J, Johnson DR, Armitage JO, Weisenburger DD, Purtilo D. Chromosomal abnormalities in indolent lymphoma. Cancer Genet Cytogenet 27:335, 1987

20. Sanger WG, Armitage JO, Bridge $J_{*}$ Weisenburger DD, Fordyce R, Purtilo DT. Initial and subsequent cytogenetic studies in malignant lymphoma. Cancer 140:3014, 1987

21. Offit $K$, Richardson ME, Quanguang C, Hampton A, Koduru PRK, Jhanwar SC, Fillippa DA, Lieberman $\mathrm{PH}_{*}$ Clarkson B, Chaganti RSK: Nonrandom chromosomal abberations are associated with sites of tissue involvement in non-Hodgkin's lymphoma. Cancer Genet Cytogenet 37:85, 1989.

22. Han $T$, Ozer $H$, Sadamori $N$, Emrich $\mathbb{L}_{*}$ Gomez GA, Henderson ES, Bloom ML, Sandberg AA. Prognostic importance of cytogenetic abnormalities in patients with chronic lymphocytic leukemia. New Engl J Med 310:288, 1984

23. Juliusson $\mathbf{N}$, Gahrton $G$. Abnormal/normal metaphase ratio and prognosis in chronic $B$ lymphocytic leukemia. Cancer Genet Cytogenet 18:307, 1985

24. Yunis JJ, Mayer MG, Amesen M, Aeppli DP, Oken MM, Frizzera G. bcl-2 and other genomic alterations in the prognosis of large-cell lymphoma. N Engl J Med 320:1047, 1989

25. Cabanillas F, Pathak S, Grant G, Hagemeister FB, McLaughlin P, Swan F, Rodriguez MA, Trujillo J, Cork A, Butler JJ. Refractoriness to chemotherapy and poor survival related to abnormalities of chromosomes 17 and 7 in Jymphoma. Am J Med 87:167, 1989

26. The non-Hodgkin's lymphoma classification project: National Cancer Institute sponsored study of classifications of non-Hodgkin"s lymphoma. Summary and description of a working formulation for clinical usage. Cancer 49:2112, 1982

27. Carbone PP, Kaplan HG, Musshoff K, Smithers DW, Tubiana M. Report of the committee on Hodgkin's disease staging classification. Cancer Res 31:1860, 1971

28. Armitage JO, Weisenburger DD, Hutchins M, Moravec DF, Dowling M, Sorensen S, Mailliard J, Okerbloom J, Johnson PS, Howe D, Bascom GK, Casey J, Linder J, Puntilo DT. Chemotherapy for diffuse large-cell lymphoma: Rapidly responding patients have more durable remissions. J Clin Oncol 4:160, 1986

29. Hamden DG, Klinger HP, eds ISCN (1985). An international system for human cytogenetic nomenclature. Basel. Karger p 1, 1985

30. Fleiss J. Statistical methods for rates and proportions. New York. John Wiley and Sons. 1973

31. Kaplan $\mathbf{E}_{\mathrm{q}}$ Meier P. Nonparametric estimation from incomplete obstervations. J Am Statist Assoc $53: 457,1958$

32. Cox DR. Regression models and life-tables (with discussion). J R Statist Soc B 34:187, 1972 
CHAPTER 4

\section{Abnormalities involving chromosome 6 in newly diagnosed patients with non-Hodgkin's lymphoma}

Harry C. Schouten, Warren G. Sanger, Dennis D. Weisenburger, and James O. Armitage, for the Nebraska Lymphoma Study Group

Cancer Genetics and Cytogenetics 1990, 47: 73-82 
Y Abstract

Several cytogenetic abnormalities involving chromosome 6 occurring in nonHodgkin's lymphoma (NHL) have been described. We report 34 newly diagnosed patients with NHL who had an abnormal chromosome 6 on initial biopsy. Monosomies $(n=5)$, trisomies $(n=6)$, deletions of $6 q(n=13)$ and isochromosomes $6 p(n=9)$ were frequently observed and translocations were rare. When compared to 70 other NHL patients with cytogenetic abnormalities, the patients with an abnormal chromosome 6 had a higher frequency of immunoblastic lymphoma $(p<0.001)$. Also, these patients were more likely to have $B$ symptoms $(p=0.02)$. Patients with a breakpoint at $6 q 11-16$ all had a deletion of the distal portion and, also, were more likely to have $B$ symptoms $(<0.001)$. The majority of patients with breakpoints at $6 q 21-25$ had a deletion associated with a lower frequency of stage $V$ disease $(p=0.03)$ and a higher complete remission $(C R)$ rate $(p=0.03)$. The patients with an $i(6 p)$ had a lower frequency of stage $I V$ disease $(p=0.03)$, and the patients with a trisomy 6 had a shorter median survival $(p=0.005)$. Our results suggest that chromosome 6 , especially the long arm, carries important information for the clinical behaviour of NHL. Future studies are necessary to resalve the molecular defects.

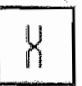

\section{Introduction}

Since Boveri first suggested the relationship between chromosomal abnormalities and malignancies (1), numerous reports have been published supporting this hypothesis (2-29). Many studies dealt with patients with nonHodgkin's lymphoma (NHL) (6-29). These patients frequently had cytogenetic abnormalities involving chromosomes $8[\mathrm{t}(8 ; 14)], 11$ [t(11;14)], or 14 and 18 [t(14;18)] (6-29).

In Catalog of Chromosome Aberrations in Cancer, Mitelman provided an extensive listing of all described abnormalities involving chromosome 6 in NHL (26). Many of these abnormalities originate from case reports. We are aware of only one study specifically dealing with structural changes in chromosome 6 in NHL (27). Several studies concerning cytogenetic analysis and NHL mention abnormalities of chromosome 6 and also describe associations with disease characteristics (7-16). However, many of these reports have limitations caused by the inclusion of a small number of patients, of patients previously treated with chemotherapy, or of describing heterogeneously managed patients.

We studied 104 previously untreated patients with chromosomal abnormalities. All were treated according to protocols of the Nebraska Lymphoma Study Group. One of our observations was that $33 \%$ of the patients had an abnormal 
Table I. Characteristics of patients with abnormal chromosome studies

\begin{tabular}{|c|c|c|c|}
\hline 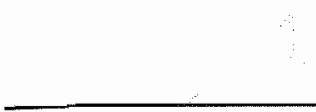 & $\Leftrightarrow$ & $\begin{array}{l}\text { palients with abnormal } \\
\text { chromosome } 6 \\
\text { number }(\%)\end{array}$ & $\begin{array}{l}\text { palients with othor } \\
\text { abnomalities } \\
\text { number } \% \text {. }\end{array}$ \\
\hline Number of patients & & 34 & 70 \\
\hline age & & 26-86 (median, 73) & $15-90\left(\right.$ median $\left._{n} 66\right)$ \\
\hline sex maleffemale & & $19 / 15$ & $35 / 35$ \\
\hline stage 1 & & $3(9)$ & $8(11)$ \\
\hline stage II & & $10(29)$ & $41(16)$ \\
\hline stage III & & $5(15)$ & $8(11)$ \\
\hline stage IV & & $16(47)$ & $43(61)$ \\
\hline $\mathrm{B} / \mathrm{T}$-cell & & $25 / 5$ & $58 / 7$ \\
\hline B symptoms & & $15(44)$ & $15(21)$ \\
\hline LDH elevated & & $20(52)$ & $28(40)$ \\
\hline bulky disease & & $7(21)$ & $15(21)$ \\
\hline extra nodal disease & & $17(50)$ & $47(67)$ \\
\hline marrow infiltration & & $10(29)$ & $29(41)$ \\
\hline skin infiltration & & $2(6)$ & $7(10)$ \\
\hline \multicolumn{4}{|l|}{ Histologic subtypes } \\
\hline small Iymphocytic & & - & 3 \\
\hline follicular small cleaved & : & - & 1 \\
\hline follicular mixed cell & $\therefore$ & 2 & 9 \\
\hline follicular large cell & & 4 & 7 \\
\hline diffuse small cleaved & & 1 & 10 \\
\hline diffuse mixed cell & 9 & 3 & 2 \\
\hline diffuse large cell & & 5 & 18 \\
\hline immunoblastic & & 15 & 9 \\
\hline lymphoblastic & & - & 5 \\
\hline small non cleaved & & - & 3 \\
\hline compasite Iymphoma & & 2 & 2 \\
\hline cytologic diagnosis only & & 2 & 1 \\
\hline
\end{tabular}

chromosome 6 (30). Here, we report on these 34 patients with newly diagnosed $\mathrm{NHL}$, all having a chromosomal abnormality involving chromosome 6 . We will discuss the correlations observed between the specific cytogenetic abnormalities and characteristics of disease.

Y Materials and Methods

\section{Patient Characteristics}

Between October 1982 and April 1988, the lymph nodes or other sites of disease of 123 patients with histologically-confirmed NHL were cytogenetically studied. The results were inconclusive in ten patients, nine patients had normal 
Table II. Clinical characteristics of patients with an abnormal chromosome 6 .

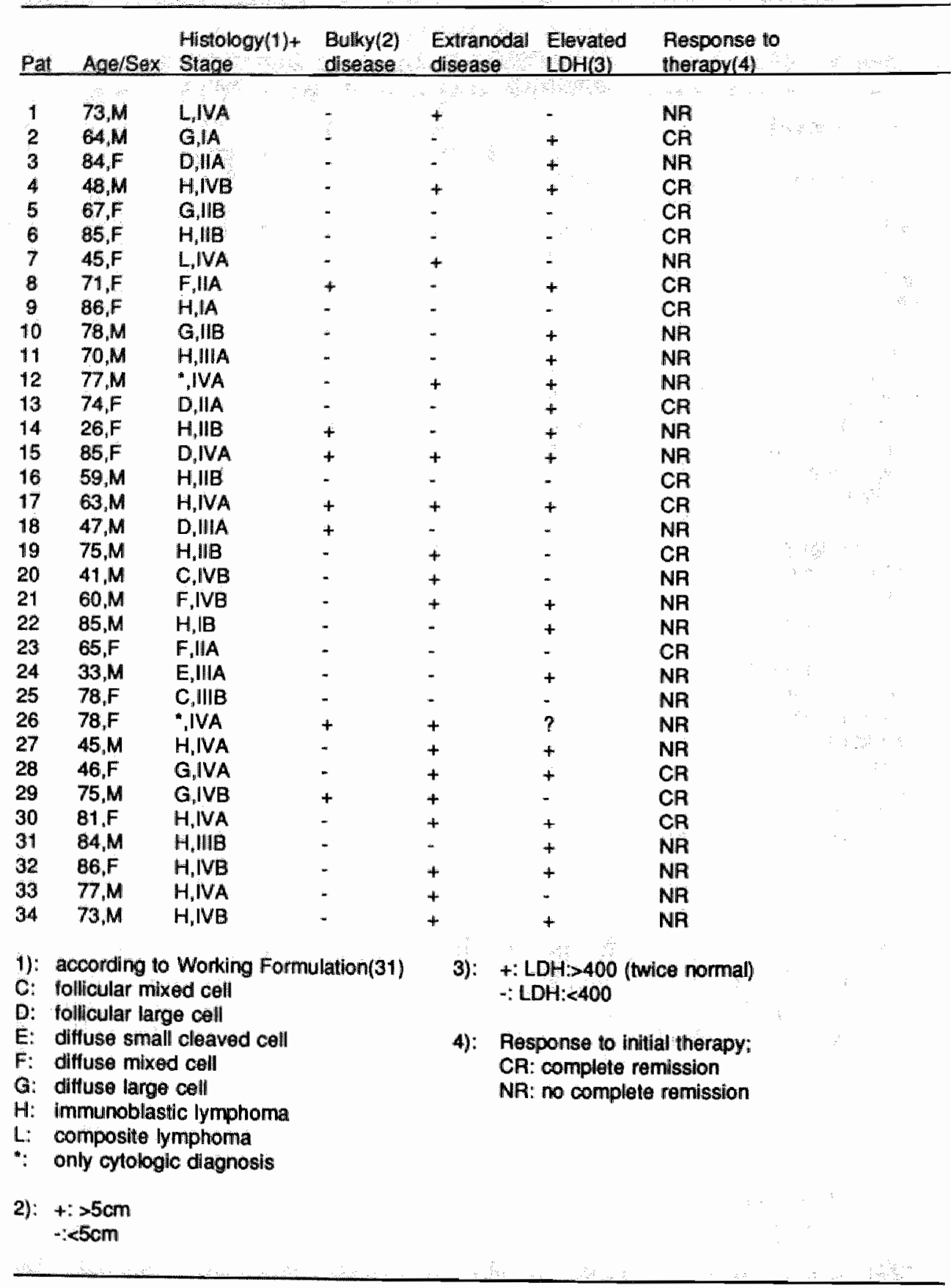


karyotypes and 104 had cytogenetically abnormal clones. Of these 104 patients 34 had an abnormality involving chromosome 6. All of the tissues examined were involved by lymphoma. Portions of the same tissue were concurrently studied for cytogeneties, histology and B-cell and T-cell markers, using an immunoperoxidase technique. The Working Formulation Classification was used (31). Staging evaluation consisted of a complete history and physical examination, chest radiograph, computed tomography scan of the abdomen and chest, and bilateral bone marrow biopsies. Stage was assigned according to the Ann Arbor system (32).

In all patients, the tumor was studied at the time of primary diagnosis. No selection criteria other than the availability of cytogenetic data at the time of diagnosis and treatment according to the Nebraska Lymphoma Study Group protocols was used. Three patients only had a cytological diagnosis.

The clinical characteristics of these patients are shown in Tables I and II. The median age of the patients with an abnormal chromosome 6 was 73 (range, 26-86). There was a slight male preponderance (56\%). Seventy five percent had a diffuse and $25 \%$ a follicular growth pattern. Twelve percent of the patients had a NHL of low grade malignancy, $38 \%$ of intermediate grade and $46 \%$ of high grade malignancy according to the Working Formulation (31). Nine percent of the patients were stage I, $29 \%$ stage II, $15 \%$ stage III and $47 \%$ stage IV. The majority had a B-cell phenotype (74\%). Forty four percent had B symptoms, $52 \%$ an elevated LDH, $21 \%$ bulky disease (diameter $>10 \mathrm{~cm}$ ), $50 \%$ extranodal localizations of disease, $29 \%$ marrow infiltration and $6 \%$ skin involvement. Relevant data regarding the patients with abnormal clones not involving chromosome 6 are also listed in Table I for comparison. The follow up of the patients was 1-55 months (median, 16 months).

\section{Treatment}

The patients were treated according to the protocols of the Nebraska Lymphoma Study Group. Patients with stage I disease were treated with radiation therapy until 1986 and more recently with radiation following two cycles of chemotherapy. The patients with stage II, III and IV disease were treated with chemotherapy. The chemotherapy regimens consisted of CAP-BOP (cyclophosphamide, adriamycin, procarbazine, bleomycin, vincristine, and prednisone) (33) for the intermediate and high grade malignant lymphomas or ChlVP (chlorambucil $12 \mathrm{mg} / \mathrm{m}^{2}$ ) p.o. days $1-5$, vincristine $1 \mathrm{mg} / \mathrm{m}^{2} \mathrm{i} . v$. day 1 and prednisone $100 \mathrm{mg}$ p.o. days $1-5$, every $3-4$ weeks) for the lymphomas of low grade malignancy. 
Table III. Listing of all karyotypes

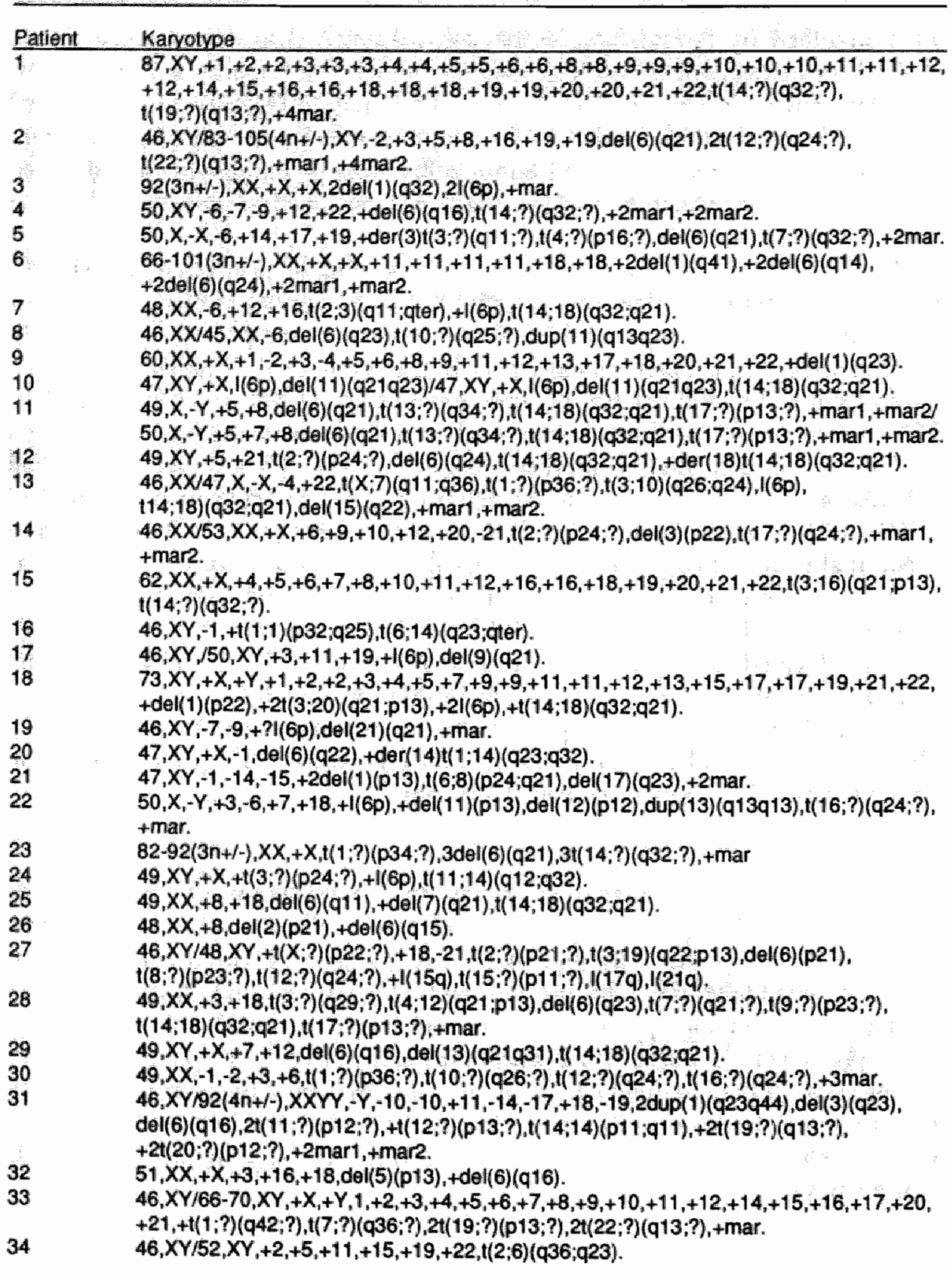


Table IV. Chromosomal abnormalities occurring in at least $15 \%$ of the patients with an abnormal chromosome 6

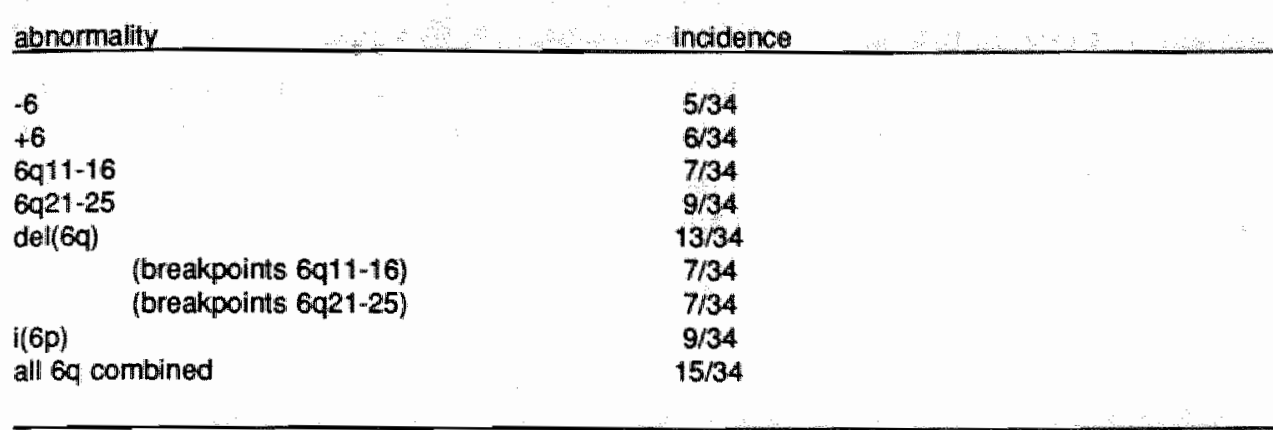

A complete remission (CR) was defined as the absence of clinically demonstrable disease after the completion of the therapy and restaging. Diseasefree survival was defined as the period of time from CR until relapse, death or present.

\section{Cytogenetic Methods}

The methods of culturing and processing of the lymph nodes are described elsewhere (19). In short, after mechanically mincing the tissue in RPMI 1640 (Gibco, Grand Island, NY) including 20\% fetal bovine serum and antibiotics the cell suspensions were incubated at $37.5^{\circ} \mathrm{C}$ and cultured for 24 and 48 hours without the use of mitogens. After the exposure to Colcemid $(0.05 \mathrm{ug} / \mathrm{ml})(\mathrm{Gibco}$, Grand Island, NY), the preparations were resuspended in 0.074 molar KCL for 10 minutes and fixed with a 3:1 mixture of methanol and glacial acetic acid. After repeating the fixation process three times, the slide preparations were made, aged overnight at $60^{\circ} \mathrm{C}$ and G-banded with Wright's stain. All metaphase plates were microscopically analyzed, recorded, and photographed. An abnormal clone was defined as two or more cells with the same structural abnormality or the same extra chromosome, or the presence of three or more cells with the same missing chromosome. If only one mitotic cell with an abnormal kiryotype was present it was considered a malignant clone if there was a structural abnormality known to be associated with lymphoma. Normal cells were considered to be present if a single cytogenetically normal cell was observed. If these criteria were not fulfilled or less than five normal mitotic cells were present or if the results were too poor to analyze, the test was classified as inconclusive and excluded from analysis. The karyotypes were designated according to the classification of the International System for Human Cytogenetic Nomenclature (ISCN 1985)(34). The cytogenetic abnormalities were mapped and their relative frequencies were callculated. 


\section{Study design}

The disease characteristics of the patients with an abnormal chromosome 6 were studied, including age, sex, histology, growth pattern, stage of disease, B symptoms, $\mathrm{LDH}$, bulky disease, B/T-cell phenotype, extranodal disease, marrow involvement, skin infiltration and response to therapy. The results were compared with the patients with other abnormal karyotypes. The Chi Square test with the Yates correction when appropriate was used to assess significance levels. The log-rank test was used for survival differences.

\section{Y Results}

Thirty four patients had an abnormality involving chromosome 6 (Table III), and 70 patients had abnormal clones not involving chromosome 6 . Of these 34 patients, six had a trisomy $6(17 \%)$ and five patients a monosomy $6(15 \%)$. Thirteen patients $(38 \%)$ had a deletion of the distal part of the long arm of chromosome 6 , in seven with a breakpoint occurring in the 6q11-16 region and seven patients in the $6 \mathrm{q} 21-25$ region. One of these patients had a del( 6 )(q24) in addition to a del( $(6)(\mathrm{q} 14)$. An i $(6 \mathrm{p})$ was observed in nine patients $(26 \%)$. A translocation involving chromosome 6 was observed in only three patients $(9 \%)$, and an abnormality involving the short arm of this chromosome only in two patients (6\%) (see Table IV).

Several abnormalities of chromosome 6 were observed to occur in association with another chromosomal change. However, most did not occur in a higher frequency than would be expected randomly. Exceptions included a combination of a dell $(6 \mathrm{q})$ and +8 in four of 16 patients ( $25 \%$, expected $11 \%$ ), a combination of a del $(6 q)$ and $a+18$ in 6 of 16 patients $(38 \%$, expected $20 \%)$ and a combination of a del $(6 q)$ and a -6 in 3 of the 16 patients (19\%, expected $5 \%$ ). Three other patients had a combination of an $i(6 p)$ and a del $(6 q)$.

The clinical characteristics of the patients with or without an abnormal chromosome 6 were comparable. However, patients with a chromosome 6 abnormality had a higher frequency of high grade histology $(p=0.05)$ and a slightly lower frequency of stage IV disease (see Table I). Fifteen of the 34 patients had immunoblastic lymphoma. This correlation was highly significant $(p<0.001)$ (see table V). However, in the patients with a large cell or immunoblastic lymphoma, the presence or absence of an abnormal chromosome 6 was not correlated with a different disease outcome or with disease characteristics. All patients with an abnormal chromosome 6 were more likely to have B symptoms $(p=0.02)$ than their counterparts with abnormal karyotypes not involving chromosome 6 . All patients with abnormalities involving the long arm of chromosome 6 also more frequently had B symptoms $(p<0.001)$. Patients with a breakpoint at $6 \mathrm{q} 11-16$ all had a deletion of the distal portion of this arm and 
Table V. Correlations between chromosomal abnormalities involving chromosome 6 occurring in at least $15 \%$ of the patients and disease characteristics

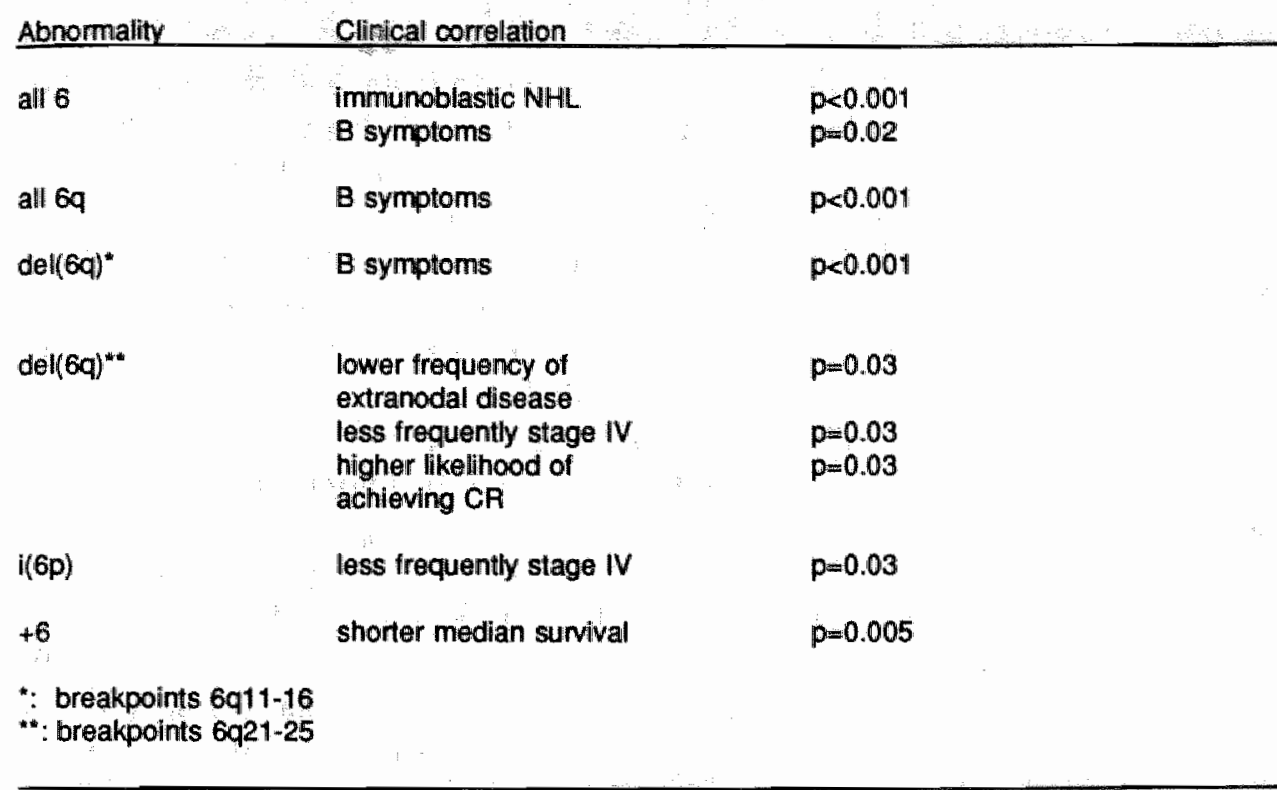

were more likely to have B symptoms $(p<0.001)$. Of the patients with a breakpoint occurring at $6 \mathrm{q} 21-25$, seven had a deletion of the distal portion and two patients had a translocation. These patients had a lower frequency of extranodal disease than expected $(p=0.03)$, less frequent stage IV disease $(p=0.03)$ and a higher likelihood of achieving a CR $(78 \%$ compared to $41 \%$; $=0.03)$. In an analysis comparing the patients with breakpoints $6 \mathrm{q} 11-16$ with those with $6 \mathrm{q} 21$ 25 , no significant differences were observed. An $i(6 p)$ was found to be correlated with a lower frequency of stage IV disease $(p=0.03)$. Patients with a trisomy 6 had a median survival of 9 months versus 37 months for the patients with other abnormalities $(\mathrm{p}=0.005)$.

\section{Discussion}

In this study we report that chromosome 6 is abnormal in $33 \%$ of newly diagnosed patients with NHL. Chromosomal changes responsible for this observation, included monosomies (-6), trisomies (+6), isochromosomes [i(6p)] and deletions [del(6)] with translocations being rare. There was a significantly higher frequency of immunoblastic lymphoma in the patients with an abnormal chromosome 6. 
Several authors previously reported that breakpoints $6 \mathrm{q} 21-25$ frequently occurred in patients with NHL $(10,11,14,16)$. Several studies $(7,9,11,12,15)$ described the association between a del $(6 \mathrm{q})$ and diffuse large cell lymphoma and others (25) with diffuse histiocytic lymphoma, although these relations were not always statistically significant. In this study only two patients had an abnormality involving $6 \mathrm{q}$ in combination with a trisomy 11 and these patients had no meningeal infiltration with lymphoma which is in contrast to the report by Levine (13). In addition, no patients in our series with $a+11$ or a $6 \mathrm{q}$ - had clinical signs of meningeal infiltration. Mecucci et al (27) reported four patients with a T-cell NHL and a rearrangement of the short arm of chromosome 6 . We only had two patients with a breakpoint in 6p, one having a B-cell and the other a Tcell phenotype. The fifth International Workshop (14) also suggested the correlation between $6 \mathrm{p}$ and T-cell phenotype, but did not observe other significant correlations between chromosome 6 and histologic or immunologic parameters.

Heim and Mitelman (20) suggested that a deletion of $6 \mathrm{q}$ was a secondary abnormality. Each patient in our study had an abnormal clone with other chromosomal abnormalities in addition to those involving chromosome 6 . However, we observed a high frequency of chromosome 6 abnormalities in this group of newly diagnosed patients. Also, there was a highly significant correlation with chromosomal abnormalities and the occurrence of immunoblastic lymphoma. Therefore a deletion $6 \mathrm{q}$ could be a primary event.

Most abnormalities are accompanied by a loss of chromosomal information located on the $6 \mathrm{q}$ arm [i.e. del(6q) and $\mathrm{i}(6 \mathrm{p})]$. It is known that the c-myb oncogene is located in the 6q21-25 region. Barletta et al (35) showed that this oncogene was still present even with a deletion in region 6q21-25. They also provided evidence for a higher $m y b$ messenger expression with the deletion. However, what will happen with the $c-m y b$ locus in patients with a deletion of the area distal from $6 \mathrm{q} 11-16$ is presently unknown. Also several patients had a deletion of $6 \mathrm{q}$ in combination with another abnormality involving 6 or $6 \mathrm{q}$. This, in relation with malignancy, might suggest the presence of tumor suppressor genes located on this chromosome. Further studies are necessary to elucidate this relation.

Our results suggest that chromosome 6 plays an important role in the development of NHL in some patients. However, the exact genetic and molecular defects still are to be resolved. 


\section{References}

1. Boveri T. Zur Frage ded Entstehung maligner Tumoren. Gustav Fischer, Jena, p. 1, 1914.

2. Nowell PC, Hungerford DA. A minute chromosome in human chronic granulocytic leukemia. Science 132:1497, 1960 (letter).

3. Heim S, Mitelman Fo Chromosome abnormalities in the myelodysplastic syndromes. Clin Haematol 15:1003, 1986.

4. Bloomfield CD, Goldman A, Alimena G, Berger R, Borgstrom GH, Brandi L, Catovsky D, delaChapelle A, Dewald GW, Garsop OM, Garwics S, Golomb HM, Hossfeld DK Mitelman F, Nilsson P. Pierre RV, Philip P, Prigogina E, Rowley JD, Sakurai M, Sandberg AA, Secker Walker LM, Tricot G, vandeBerghe H, Van Orshoven A, Vuopio $P$, Whang-Pang J. Chromosomal abnormalities identify high-risk and low-risk patients with acute lymphoblastic leukemia. Blood 67:415, 1986 .

5. Rowley JD, Alimena G, Garson OM, Hagemeyer A, Mitelman F, Prigogina EL. A collaborative study of the relationship of the morphological type of acute non-lymphocytic leukemia with patient age and karyotype. Blood 59:1013, 1982.

6. Han T, Sadamori N, Ozer H, Gajera R, Gomez GA, Henderson ES, Bhargava A, Fitzpatrick J, Minowada J, Bloom ML, Sandberg AA. Cytogenetic studies in 77 patients with chronic lymphocytic leakemia: Correlations with clinical, immunologic, and phenotypic data. $f$ Clin Oncol 2:1121, 1984.

7. Yunis JJ, Frizzera G, Oken MM, McKenna J, Theologides A, Amesen M. Multiple recurrent genomic defects in follicular lymphoma. A possible model for cancer. $\mathrm{N}$ Engl $J$ Med 316:79, 1987.

8. Kakati S, Kowalczyk JR, Becher $\mathbb{R}_{*}$ Sandberg AA. Chromosome changes in secondary lymphoma. Cancer Genet Cytogenet 17:29, 1985.

9. Yunis J, Oken MM, Theologides A, Howe RB, Kaplan ME. Recurrent chromosomal defects are found in most patients with non-Hodgkin"s lymphoma. Cancer Genet Cytogenet 13:17, 1984.

10. Kristoffersson U, Heim S, Mandahl N, Olsson H, Ranstam J, Akerman M, Mitelman F, Prognostic implication of cytogenetic findings in 106 patients with non-Hodgkin's lymphoma. Cancer Genet Cytogenet 25:55, 1987.

11. Bloomfield CD, Arthur DC, Frizzera G, Levine EG, Peterson BA, Gajl-Peczalska KJ. Nonrandom chromosome abnormalities in Iymphoma. Cancer Res 43:2975, 1983.

12. Koduru PRK, Filippa DA, Richardson ME, Jhanwar SC, Chaganti SR, Koziner B, Clarkson BD, Lieberman $\mathrm{PH}_{*}$. Chaganti RSK. Cytogenetic and histologic correlations in malignant lymphoma. Blood 69:97, 1987.

13. Levine EG, Arthur DC Frizzera G, Peterson BA, Hurd DD, Bloomfield CD. Cytogenetic abnormalities predict clinical outcome in non-Hodgkin lymphoma. Ann Intern Med 108:14, 1988.

14. Fifth Intemational Workshop on Chromosomes in Leukemia-Lymphoma. Correlation of chromosome abnomalities with histologic and immunologic characteristics in non-Hlodgkin's lymphoma and adult $T$ cell leukemia-lymphoma. Blood 70:1554, 1987.

15. Levine EG, Arthur DC, Frizzera $G$, Peterson BA, Hurd $D D_{*}$ Bloomfield $C D$. There are differences in cytogenetic abnormalities among histologic subtypes of the non-Hodgkin's lymphomas. Blood 66:1414, 1985.

16. Kaneko $Y_{*}$ Abe $\mathbb{R}$, Sampi $K$, Sakuarai $M$, An analysis of chromosome findings in non-Hodgkin's lymphomas. Cancer Genet Cytogenet 5:107, 1982.

17. Juliusson G, Robent $K_{\text {, }}$ Ost A, Friberg K, Biberfeld P, Nilsson B, Zech L, Gahrton G. Prognostic information from cytogenetic analysis in chronic B-lymphocytic leukemia and leukemic immunocytoma. Blood 65:134, 1985. 
18. Kaneka $Y$, Rowley JD, Variakojis D, Haren JM, Ueshima $Y$, Daly $\mathrm{K}$, Kluskens LF, Prognostic implications of karyotype and morphology in patients with non-Hodgkin's lymphoma. Int J Cancer 32:683, 1983.

19. Sanger WG, Amitage JO, Bridge J, Weisenburger DD, Fordyce R, Purtilo DT Initial and subsequent cytogenetic studies in malignant lymphoma. Cancer 140;3014, 1987.

20. Heim S, Mitelman F. Malignant Lymphomas. In Cancer Cytogenetics. Heim S, Mitelman F, Ed. Alan R. Liss, Inc. New-York, 1987. p. 201.

21. Speaks SL, Sanger WG, Linder J, Johnson DR, Armitage JO, Weisenburger DD, Purtilo D. Chromosomal abnormalities in indolent lymphoma. Cancer Genet Cytogenet 27:335, 1987.

22. Jullusson $N$, Gahrton $G$ Abnormal/normal metaphase ratio and prognosis in chronic $B$ lymphocytic leukemia. Cancer Genet Cytogenet $18: 307,1985$.

23. Han T, Ozer H, Sadamori N, Emrich L, Gomez GA, Henderson ES, Bloom ML, Sandberg AA. Prognostic importance of cytogenetic abnormalities in patients with chronic lymphocytic leukemia. New Engl J Med 310:288, 1984.

24. Armitage JO, Sanger WG, Weisenburger DD, Harrington DS, Linder J, Bierman PJ, Vose JM, Purtilo DT. Correlation of secondary cytogenetic abnomalities with histologic appearance in non-Hodgkin's lymphomas bearing t(14;18)(q32;q21). J Natl Cancer Inst 80:576, 1988.

25. Rowley JD, Fukahara $S$. Chromosome studies in non-Hodgkin's lymphomas. Semin Oncol 7;255, 1980.

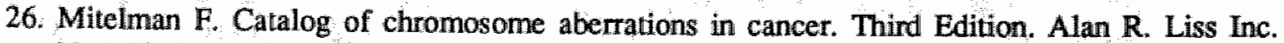
New-York, 1988. p. 239.

27. Mecucci C, Michaux J-L, Tricot G, Louwagie A, van den Berghe H. Rearrangements of the short arm of chromosome no 6 in T-cell lymphomas. Leukemia Res 9:1139. 1985.

28. Juliusson G. Immunologic and cytogenetic studies improve prognosis prediction in chronic Blymphocytic leukemia: A multivariate analysis of 24 variables. Cancer 58:688, 1986.

29. Levine EG, Arthur DC, Gajl-Peczalska KJ, LeBien TW, Peterson BA, Hurd DD, Bloomfield CD. Correlations between immunological phenotype and karyotype in malignant lymphoma. Cancer Res 46:6481, 1986.

30. Schouten HC, Sanger WG, Weisenburger DD, Armitage JO. Chromosomal abnormalities in untreated patients with non-Hodgkin's Iymphoma: associations with hilstology, clinical characteristics and treatment outcome. Blood 75:1841, 1990.

31. The non-Hodgkin's lymphoma classification project. Nationall Cancer Institute sponsored study of classifications of non-Hodgkin's lymphoma. Summary and description of a working formulation for clinical usage. Cancer 49:2112,1982.

32. Carbone PP, Kaplan HG, Musshoff $K$, Smithers DW, Tubiana M. Report of the committee on Hodgkin's diseiase staging classification. Cancer Res 31:1860, 1971.

33. Armitage JO, Weisenburger DD, Hutchins $M$, Moravec DF, Dowling $M_{4}$ Sorensen $S$, Mailliard J, Okerbloom J, Johnson PS, Howe D, Bascom GK, Casey J, Linder J, Purtilo DT. Chemotherapy for diffuse large-cell lymphoma: Rapidly responding patients have more durable remissions. J Clin Oncol 4:160, 1986.

34. Hamden DG, Klinger HP, eds ISCN. An international system for human cytogenetic nomenclature. Karger. Basel. 1985. p. 1.

35. Barletta C. Pelicci P-G, Kenyon LC, Smith SD, Dalla-Favera RD. Relationship between the cmyb locus and the 6q-chromosomal aberration in leukemias and lymphomas. Science 238:1064,
1987 . 
CHAPTER 5

\section{Chromosomal abnormalities in patients with non-cutaneous T-cell non-Hodgkin's lymphoma}

Harry C. Schouten, Warren G. Sanger, Dennis D. Weisenburger, and James $O$. Armitage for the Nebraska Lymphoma Study Group

European Journal of Cancer 1990, 26: 618-622 
Y Abstract

In contrast to non-Hodgkin's lymphoma's (NHL) with a B-cell phenotype, almost no data have been reported dealing with correlations between chromosomal abnormalities and characteristics of the disease in patients with $T$-cell NHL. In a retrospective analysis we studied all patients with a non-cutaneous T-cell NHL and chromosomal abnormalities that were evaluated at our institution; twenty patients could be identified. Most frequently numerical abnormalities involving chromosomes $3,4,5,22$ and $X$ were observed. Structural abnormalities involved mainly the breakpoints 1q22-25, 6q23 and 11 13. There appeared to be an association between +7 , breakpoints $2 p 23-24$, $4 p 14-15,8 q 21$ and the presence of extranodal disease. All patients with +7 had a diffuse mixed histology. Patients with $+2,+3,+11,+17,+18,+20$ or breakpoint 1q22-25 had an immunoblastic lymphoma and patients with breakpoints 9q32-34 or $14 q 12$ had a lymphoblastic lymphoma. No correlations were observed between chromosomal abnormalities and response to therapy, survival or phenotypic markers. Abnormalities involving the chromosomes containing the $T$-cell receptor genes and $T$-cell markers were infrequent. Several breakpoints were identified that correlate with already described oncogenes.

Y. Introduction

Several studies describing chromosomal abnormalities in patients with nonHodgkin's lymphoma (NHL) have been published. They not only suggest that some abnormalities occur frequently, but also that particular karyotypes are correlated with characteristics of the disease (1-11). The overwhelming majority of patients studied have a NHL with a B-cell phenotype. The number of patients with a T-cell NHL cytogenetically studied is much smaller $(6,9,12-16)$ and few correlations between chromosomal abnormalities and characteristics of the disease have been reported.

Therefore, in order to analyze the particular chromosomal abnormalities that are related with non-cutaneous T-cell NHL, we performed a retrospective analysis of all patients with a non-cutaneous T-cell NHL who had an abnormal cytogenetic analysis and were treated by the Nebraska Lymphoma Study Group. 
Table I. Clinical Information About Patients With A Non-Cutaneous T-cell NHL And Chromosomal Abnormalities

\begin{tabular}{|c|c|c|c|c|c|c|}
\hline Pat & Age/Sex & $\begin{array}{l}\text { Histology } \\
+ \text { Stage(1) }\end{array}$ & $\begin{array}{l}\text { Bulky } \\
\text { Disease(2) }\end{array}$ & $\begin{array}{l}\text { Extranodal } \\
\text { Disease(3) }\end{array}$ & $\begin{array}{l}\text { Elevated } \\
\mathrm{LDH}(4)\end{array}$ & $\begin{array}{l}\text { FirstTherapy (5) } \\
+ \text { DFS Imal } 6 \text { ) }\end{array}$ \\
\hline 1 & $56 / \mathrm{M}$ & $\| B L$ IIa & + & . & . & CAPBOP 9 \\
\hline 2 & $71 / F$ & DW Ila & & - & . & CAP-BOP,28 \\
\hline 3 & $86 / \mathrm{F}$ & $\| B L$ la & $\therefore$ & - & $=$ & $\mathrm{RT}_{1}, 12$ \\
\hline 4 & $59 / \mathrm{M}$ & $\| \mathrm{BL} / \mathrm{Ib}$ & + & $=$ & - & CAP-BOP, $60+$ \\
\hline 5 & $58 \mathrm{MM}$ & $\triangle B L \quad I V b$ & . & $M$ & - & CAPBOP, 8 \\
\hline 6 & $23 / M$ & IBL NA & NA & NA & $\mathrm{NA}$ & NA \\
\hline 7 & $60 / \mathrm{M}$ & $\mathrm{DM} \| \mathrm{Vb}$ & $-\quad 1 !$ & $\mathrm{L}_{\mathbf{1}} \mathrm{G}, \mathrm{H}$ & - & CAPAOP 0 \\
\hline 8 & $21 M$ & LB $\| V a$ & $=$ & $\mathbf{M}$ & - & CAP-BOP 23 \\
\hline 9 & $73 / M$ & IBL IVb & - & $M$ & - & CAP-BOP,2 \\
\hline 10 & $77 / F$ & DS IVa & + & $M_{n} S$ & + & CAP BOP, 0 \\
\hline 11 & $75 / \mathrm{M}$ & DS IVa & - & $M$ & $=$ & CAP BOP,O \\
\hline 12 & $15 / F$ & LB lla & 4 & $\therefore$ & + & CAP-BOP, 8 \\
\hline 13 & $22 / \mathrm{M}$ & $\mathrm{LB} \quad \mathrm{Va}$ & * & $M$ & + & CAP-BOP, 12 \\
\hline 14 & 37/M & $\mathrm{DM} \mathrm{IVa}$ & - & $\mathbf{S}$ & - & CAP-BOP, $53+$ \\
\hline 15 & $22 / M$ & LB la & $+\quad$ & $=\quad 1 \quad:$ & $\therefore$ & * \\
\hline 16 & $74 / F$ & DM lla & NA & $S, N$ & NA & $\star$ \\
\hline 17 & $64 / F$ & IBL II & . & - & - & $\star$ \\
\hline 18 & $17 / \mathrm{M}$ & DN IVb & - & $\mathrm{M}_{\mathrm{a}} \mathrm{H}$ & - & * \\
\hline 19 & $68 / F$ & IBL NA & NA & NA & NA & NA \\
\hline 20 & $91 / M$ & IBL NA & NA & NA & NA & NA \\
\hline
\end{tabular}

1) Histologlc subtype (17), DS affuse small cleaved NHL; DM diftuse mixed NHL; DL : diffuse; large cell $\mathrm{NHL}_{\text {; }} \mathrm{BL}$ : Immunoblastic bymphoma; LB ; lymphoblastic Iymphoma

2) Bulky disease: $+>5 \mathrm{~cm}_{n}<5 \mathrm{~cm}$; $\mathrm{NA}$ : no information avallable

3) Extranodal disease: L: lung; G: gastrointestinal tract; $S$ : skin; H: liver; $M$ : marrow; $N$ : nasophanyn; NA: no information available

4) +: elevated (twice normal); -: normal or elevated less twice normal; NA: no information available

5) RT: involved field radiotherapy: CAP-BOP: cyclophosphamide, doxorubicin, procarbazine, bleomyoun, vincristine, and prednisone (19)" "cytogenetic analysis at relapse

6) Disease-tree survival 
Y Materials and Methods

\section{Patient Characteristics}

In a retrospective analysis of the records of the Nebraska Lymphoma Study Group 20 patients could be identified with non-cutaneous T-cell NHL who had an abnormal cytogenetic analysis. All tissues examined were involved with lymphoma. A piece of the same tissue utilized for cytogenetic analysis was also studied histologically and, using an immunoperoxidase technique, was shown to be of T-cell origin. The Working Formulation Classification was used (17).

The clinical staging consisted of a complete history and physical examination, chest radiograph, computed tomography scan of the abdomen and chest, and bone marrow biopsy. The patients were staged according to the Ann Arbor system (18).

In 14 patients (p1-14), the tumor was studied at the time of primary diagnosis; in four patients (p15-18) the tumor was studied at relapse. For three patients $(\mathrm{p} 6,19,20)$ no other information than the histologic diagnosis, age and

Table II. Abnormal Karyotypes of Patients with T-Cell NHL.

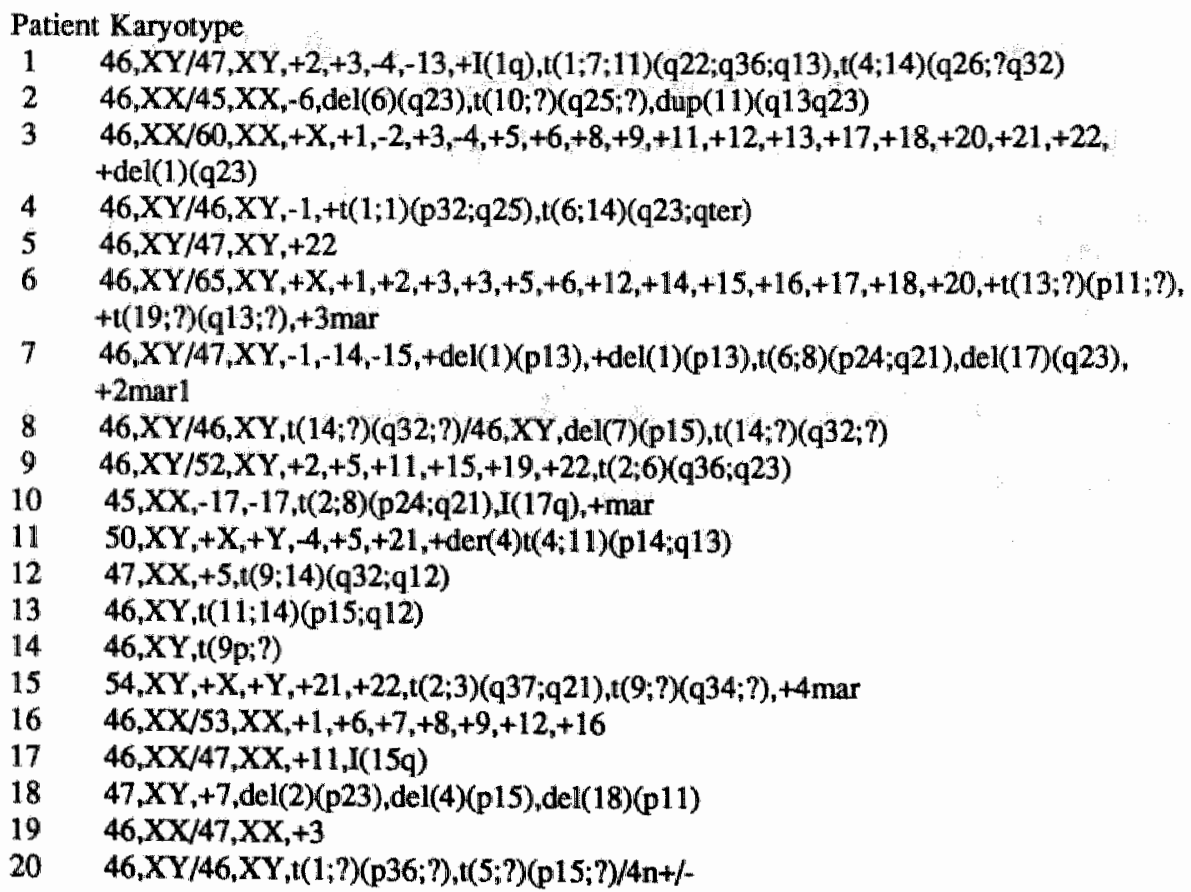


sex was available, because they were only referred for histologic and cytogenetic analysis.

The clinical characteristics of the patients are listed in Table I. The median age was 58 years (range, $15-91$ ). There was a male preponderance $(65 \%)$. No patients with cytogenetic abnormalities had a NHL of low grade malignancy, seven patients had a NHL of intermediate grade and 13 patients of high grade malignancy according to the Working Formulation (17). Two patients had stage I disease, five stage II disease, one stage III disease and nine stage IV disease. Twenty-five percent had B symptoms, $15 \%$ an elevated LDH (twice normal value), $35 \%$ bulky disease (diameter $>5 \mathrm{~cm}$ ), $50 \%$ extranodal localizations of disease, $35 \%$ marrow infiltration and $15 \%$ skin involvement.

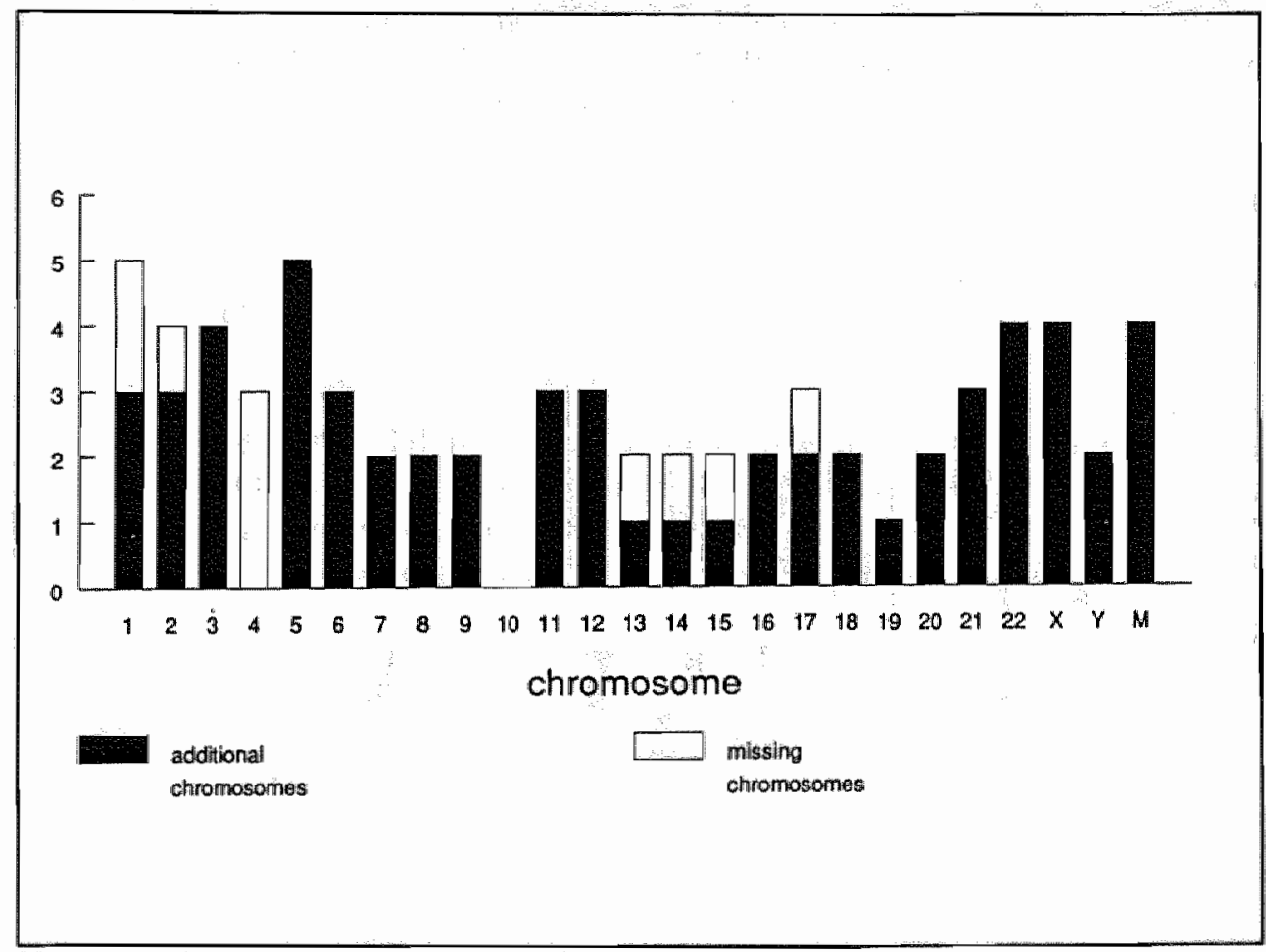

Figure 1: The numbers of patients with missing and additional chromosomes.

Cytogenetic Methods

The methods of culturing and processing of the lymph nodes are described elsewhere (20). In short, after mechanically mincing the tissue in RPMI 1640 (Gibco, Grand Island, NY) including $20 \%$ fetal bovine serum and antibiotics the cell suspensions were incubated at $37.5^{\circ} \mathrm{C}$ and cultured for 24 and 48 hours 
without the use of mitogens. After the exposure to Colcemid (0.05ug/ml) (Gibco, Grand Island, NY), the preparations were resuspended in 0.074 molar KCL for 10 minutes and fixed with a 3:1 mixture of methanol and glacial acetic acid. After repeating the fixation process three times, the slide preparations were made, aged overnight at $60^{\circ} \mathrm{C}$ and G-banded with Wright's stain. All metaphase plates were microscopically analyzed, recorded, and photographed. An abnormal clone was defined as two or more cells with the same structural abnormality or the same extra chromosome, or the presence of three or more cells with the same missing chromosome. Normal cells were considered to be present if a single cytogenetically normal cell was seen. If these criteria were not fulfilled or less than 5 normal mitotic cells were present or the results were to poor to analyze, the test was classified as inconclusive and excluded from analysis. The karyotypes were designated according to the classification of the International System for Human Cytogenetic Nomenclature (ISCN 1985) (21).

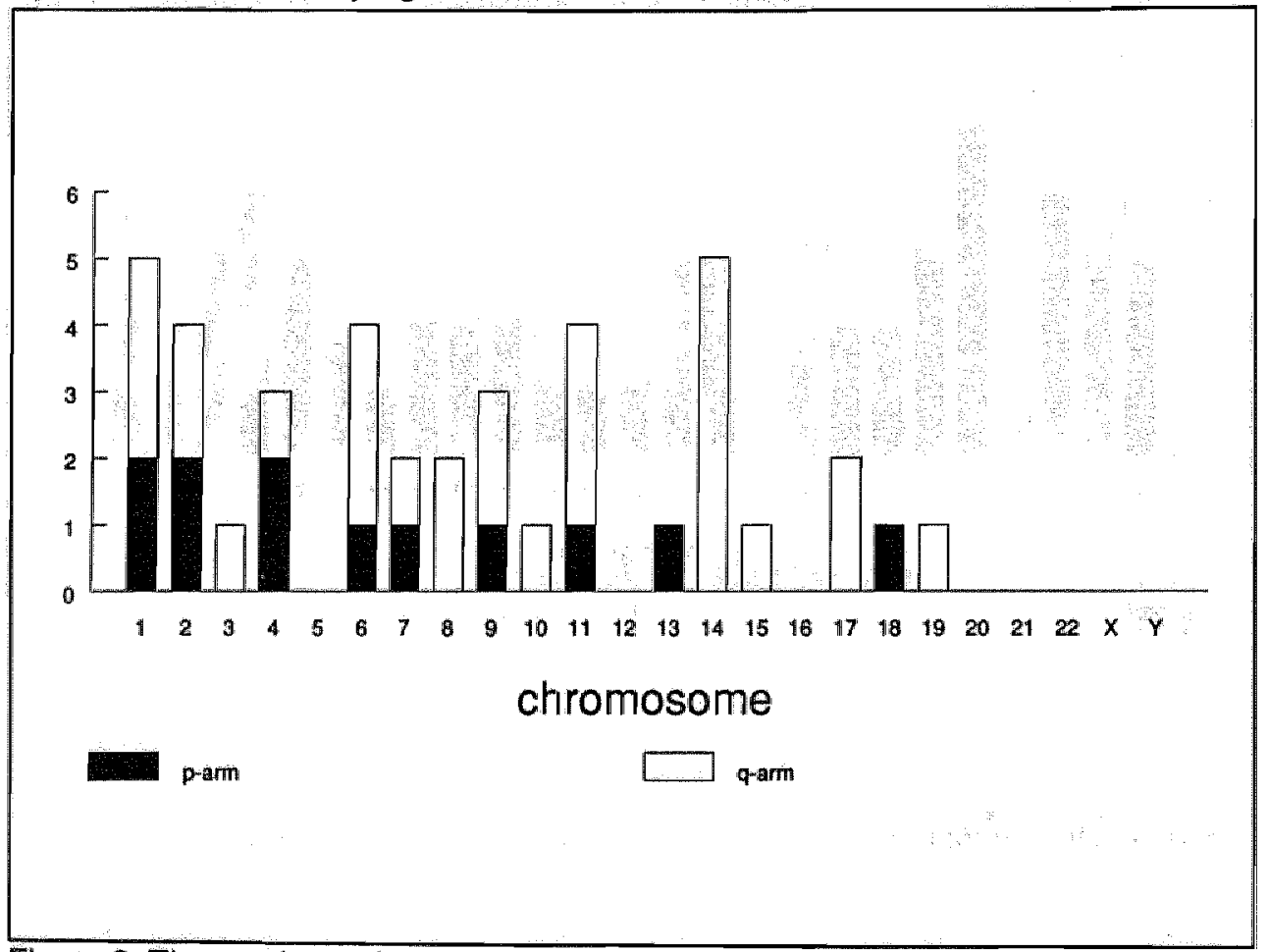

Figure 2. The numbers of patients with structural abnormalities involving the short (p) and the long (q) arm. 
Results

Twenty patients with a non-cutaneous T-cell NHL and an abnormal karyotype were identified. In 13 patients (p1-9 and 16, 17, 19, 20) a mixture of normal and abnormal cells was found and seven patients (p10-15 and 18) only displayed abnormal karyotypes. Patient 8 appeared to have two cytogenetically abnormal clones of malignant cells having the $14 \mathrm{q}+$ rearrangement in common (see table II). All but three patients had numerical abnormalities. Most frequently, gains of chromosomes $3,5,22$ and $\mathrm{X}$ were observed, but also gains of chromosomes 1,2,6,11,12 and 21 were found in three patients each (fig 1). In four patients marker chromosomes were present. Monosomies were also found and occurred more than once in chromosome 2 and 4 . Combining these numerical abnormalities chromosomes 1 and 5 were involved in five patients each, and the chromosomes $2,3,22$ and $\mathrm{X}$ in four patients each.

Structural abnormalities were found in 18 patients. The distribution of the abnormalities is shown in fig 2 . Breakpoints $2 \mathrm{q} 36-37,2 \mathrm{p} 23-24,4 \mathrm{p} 14-15,8 \mathrm{q} 21$, $9 q 32-34,14 q 12$ and $14 q 32$ were each involved in two patients and 1q22-25, $6 \mathrm{q} 23$ and $11 \mathrm{q} 13$ each in three patients. One patient (p13) had a $\mathrm{t}(11 ; 14)(\mathrm{p} 15 ; \mathrm{q} 12)$.

All patients with $+7(n=2)$, breakpoints $2 p 23-24(n=2), 4 p 14-15(n=2)$ or $8 \mathrm{q} 21(\mathrm{n}=2)$ had extranodal disease. All patients with a breakpoint $8 \mathrm{q} 21(\mathrm{n}=2)$ or $+8(n=2)$, or $+11(n=3)$ or a breakpoint $6 \mathrm{q} 23(\mathrm{n}=3)$ had a higher age than the median of the entire group. The patients with $a+7$ both had diffuse mixed lymphoma. All patients with a $+2(n=3),+3 \quad(n=4),+11 \quad(n=3),+17 \quad(n=2),+18$ $(n=2),+20 \quad(n=2)$ or a breakpoint $1 \mathrm{q} 22-25 \quad(n=3)$ had an immunoblastic lymphoma. All the patients with breakpoint $9 \mathrm{q} 32-34(\mathrm{n}=2)$ or $14 \mathrm{q} 12(\mathrm{n}=2)$ had lymphoblastic lymphoma and were younger. The patients with $14 \mathrm{q} 12$ both had an elevated LDH. No correlations were found between a specific chromosomal abnormality and response to therapy or survival. We did not observe any relation between a particular chromosomal abnormality and the presence or absence of individual phenotypic markers (Table III).

\section{Y Discussion}

We describe the chromosomal abnormalities observed in 20 patients with a non-cutaneous T-cell NHL. A variety of abnormalities were found. These abnormalities could possibly play a role in the development of the disease. This is most likely for the numerical abnormalities involving chromosomes $3,4,5$, 22 and X (each in at least three patients) and the structural abnormalities occurring at the breakpoints 1q22-25, 6q23 and 11q13 (each in three patients). Several 
Table III. Immunologic Phenotypes

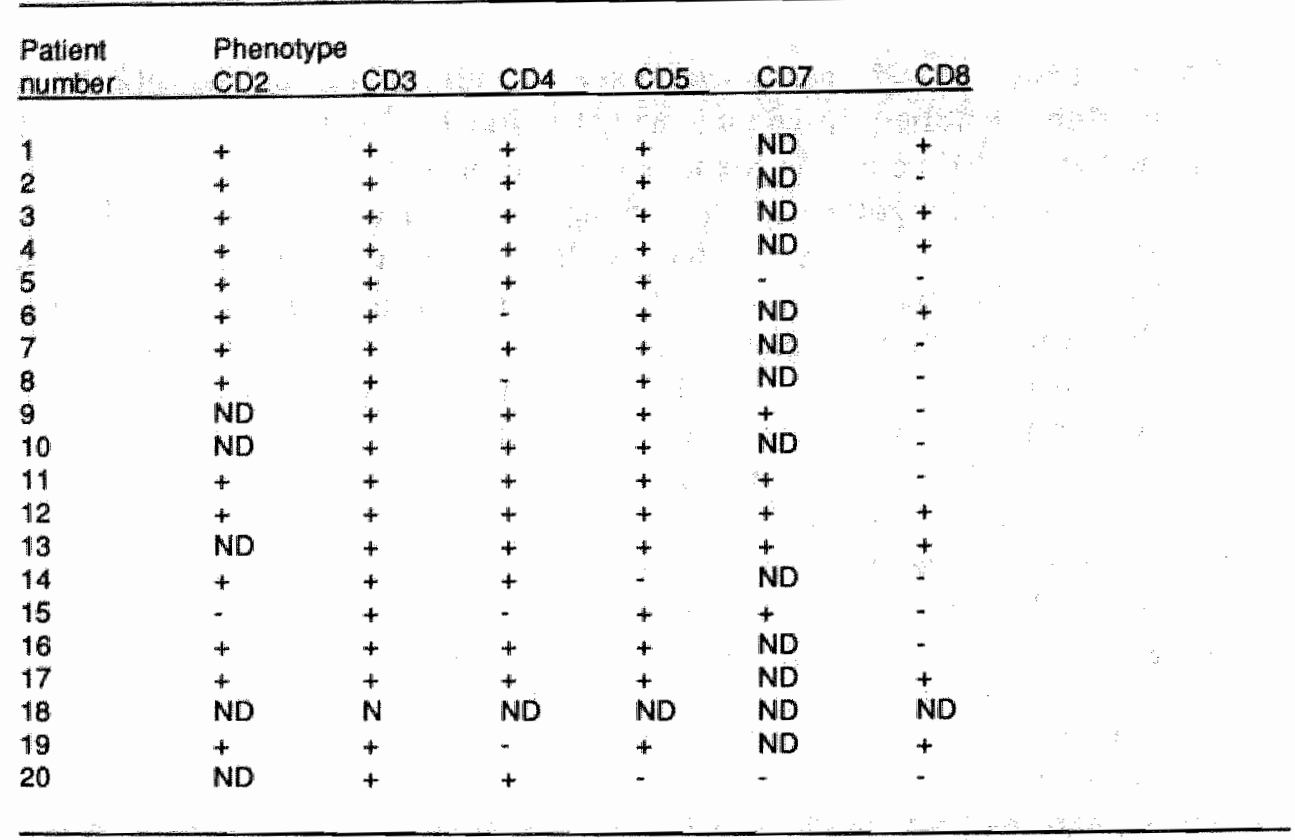

other abnormalities were related with characteristics of disease.

Only one patient had a $t(1 ; ; 14)$, known to be associated with a T-cell phenotype (22-27). All other previously described abnormalities like $\mathrm{t}(8 ; 14)(\mathrm{q} 24 ; \mathrm{q} 11), \quad \mathrm{t}(10 ; 14)(\mathrm{q} 23 ; \mathrm{q} 11.2)$, inv(14)(q11; $\mathrm{q} 32), \mathrm{t}(14 ; 14)(\mathrm{q} 11 ; \mathrm{q} 32)$, $\mathrm{t}(12 ; 14)(\mathrm{q} 24 ; \mathrm{q} 11), \mathrm{t}(7 ; 9)(\mathrm{q} 34 ; \mathrm{q} 33)$ and $\mathrm{t}(1 ; 14)(\mathrm{p} 32 ; \mathrm{q} 11)$ were not observed $(28)$. The T-cell receptor alpha and delta genes (TcRa and TcRd) are located on $14 \mathrm{q} 11(25,27)$ and an as yet unrecognized oncogene is possibly located at $11 \mathrm{pl3}$ 15 (28). In our study two patients had a breakpoint at 14q12, in or close to this gene and only one patient had an abnormality involving $11 \mathrm{p} 15$. The other TcR genes are located at $7 \mathrm{p} 15$ (gamma)(29) and at $7 \mathrm{q} 35$ (beta)(30). One patient had a breakpoint at $7 \mathrm{p} 15$ and another at $7 \mathrm{q} 36$ (close to TcR beta). Tcl-3 is located at $9 \mathrm{q} 34$ (31). This area was abnormal in one patient; another had an abnormality involving $9 \mathrm{q} 32$. There is some evidence that breakpoint $17 \mathrm{q} 23$ might be of importance in T-cell neoplasms(32); we had one patient with that breakpoint although not $\mathrm{t}(9 ; 17)$ as was previously reported. So, in our study only a minority of patients had abnormalities of chromosomes involving the TcR genes as reported by others (12), and $14 \mathrm{q} 32$ was part of the abnormality in only two patients in contrast to others who reported a higher incidence (12). The genes for the $\mathrm{CD} 2, \mathrm{CD} 7$ and $\mathrm{CD} 8$ are located on the chromosomes 4,17 and 2 respectively (33-35); no relation was found between these chromosomes and the presence 
or absence of these markers. Interestingly, the breakpoints occurring most frequently (1q22-25, 6q23 and 11q13) are known to be correlated with the oncogenes $s k i$, myb and bcl-1/int-2 (36).

In a recent study, Berger et al (12) published their results for 17 patients and gave an overview of the literature. They observed that chromosomes 1 and $6 \mathrm{q}$ and breakpoints $2 \mathrm{p} 11-14,2 \mathrm{p} 23-35,17 \mathrm{cen}, 9 \mathrm{p} 21-23$ and $10 \mathrm{p} 13-15$ are of importance. In addition to Berger et al's observation we provided evidence for the importance of chromosomes $3,4,5,22$ and X. Levine et al (5) also observed a high frequency of breaks at $1 \mathrm{q} 21,2 \mathrm{q} 21,3 \mathrm{q} 27,4 \mathrm{q} 21$ and $17 \mathrm{q} 21$ and also +19 in relation to T-cell lymphoma. Two of their patients with $a+7$ had a diffuse mixed histology as in our patients. However, Levine's patients with a large cell or lymphoblastic NHL did not have the chromosomal abnormalities we observed. The importance of chromosome 3 has already been discussed (37). In our study +3 was related with an immunoblastic lymphoma. Fujita et al (38) observed this abnormality in a patient with a large cell lymphoma but also in a patient with a diffuse mixed NHL. The fifth International Workshop (9) observed that +3 was always associated with a diffuse mixed type or adult T-cell leukemia/lymphoma. We did not observe abnormalities of $14 p$ and $19 p$, as described by Fujita et al (38). In our study a +12 was always accompanied by other cytogenetic abnormalities and never with small lymphocytic histology as reported elsewhere (9). In our study only one patient had a $6 \mathrm{p} 24$ breakpoint close to $6 \mathrm{p} 23$ shown to be correlated with a T-cell phenotype by others $(6,9)$. We could not confirm the significant correlation between $1 \mathrm{p}$ and T-cell NHL (9); only two patients had an abnormal 1p, with different breakpoints. We are not aware of reports suggesting correlations between a particular chromosomal abnormality and age or presence of extranodal disease.

Chromosomal studies in malignant lymphoma are very promising in unraveling correlations between cytogenetic abnormalities and characteristics of disease. Future studies involving more patients and also including oncogene analysis are necessary to enhance our knowledge. 


\section{References}

1. Rowley JD, Fukahara S. Chromosome studies in nom-Hodgkin s lymphomas, Semän Oncol 7:255, 1980

2. Kaneko $Y$, Rowley JD, Variakojis D, et al Prognostic implications of karyotype and morphology in patients with non-Hodgkin's lymphoma. Int I Cancer $32: 683,1983$.

3. Bloomfield CD, Arthur DC, Frizzera G, Levine EG, Peterson BA, Gajl-Peczalska KJ Nonrandom chromosome abnomalities in lymphoma, Cancer Res 43:2975, 1983.

4. Juliusson $\mathrm{G}, \mathrm{Roben} \mathrm{KH}, \mathrm{OBt} \mathrm{A}$, et al. Prognostic information from cytogenetic analysis in chronic B-lymphocytic leulkemia and leukemic immunocytoma. Blood 65:134, 1985.

5. Levine BG, A rthur DC, Gajl-Peczalska KJ, et al. Comelations between immunological phenotype and karyotype in malignant lymphoma. Cancer Res 46:6481, 1986.

6. Mecucci C, Michaux I-L, Tricot G, Low wagie $A_{*}$ van den Berghe H. Rearrangements of the short arm of chromosome no 6 in T-cell lymphomas. Leukemia Res 9:1139, 1985.

7. Yunis JI, Oken MM, Theologides A, Howe RB, Kaplan ME Recurrent chromosomal defects are found in most patients with non-Hodgkin's lymphoma. Cancer Genet Cytogenet 13:17, 1984.

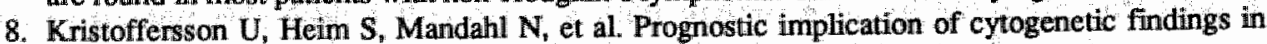
106 patients with non-Hodgkin's lymphoma. Cancer Genet Cytogenet 25:55, 1987.

9. Fifth International Workshop on Chromosomes in Leukemia-Lymphoma Correlation of chromosome abnormalities with histologic and immunologic characteristics in non-Hodgkin's Jymphoma and adult $\mathrm{T}$ cell leukemia-lymphoma Blood 70:1554, 1987.

10. Levine EG, Arthur DC, Frzzera G, Peterson BA, Hurd DD, Bloomfield CD. Cytogenetic abnormalities predict clinical outcome in non-Hodgkin lymphoma. Ann Intern Med 108:14, 1988.

11. Koduru PRK, Filippa DA, Richardson ME, et al. Cytogenetic and histologic correlations in malignant lymphoma. Blood 69:97, 1987.

12. Berger $\mathbf{R}$, Baranger L, Berheimm $A$, Valensi F, Flandrin $G$. Cytogenetics of T-cell malignant lymphoma. Report on 17 cases and review of the chromosomal breakpoints. Cancer Genet Cytogenet $36: 123,1988$.

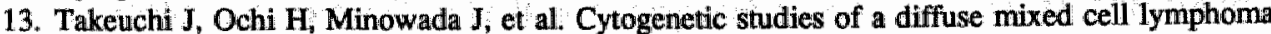
of $\mathrm{T}$ cell origin. Cancer Genet Cytogenet 14.257, 1985.

14. Ueshima $Y_{1}$ Rowley JD, Variakojis D, Winter J, Gordon L. Cytogenetic studies on patients with chronic T cell leukemia/tymphoma. Blood 63,1028, 1984.

15. Lakalla-Paranko $T$. Franssila $K$, Lappalainen $K$, et al. Chromosome abnormalities in peripheral T-cell lymphoma. Br J Haematol 66:451, 1987.

16. Sanger WG, Weisenburger DD, Amitage JO, Puntilo DT. Cytogenetic abnormalities in noncutaneous peripheral T-cell lymphoma. Cancer Genet Cytogenet 23:53, 1986.

17. The non-Hodgkin's lymphoma classification project: National Cancer Institute sponsored study of classiffications of non-Hodgkin"s lymphoma. Summary and description of a working formulation for clinical usage. Cancer 49:2112, 1982.

18. Carbone PP, Kaplan HG, Musshoff K, Smithers DW, Tubliana M. Report of the committee on Hodgkin's disease staging classification. Cancer Res $31: 1860,1971$.

19. Armitage $\mathrm{H}$, Weisenburger $\mathrm{DD}$, Hutchins $\mathrm{M}$, et al. Chemotherapy for diffuse large-cell lymphoma: Rapidly responding patients have mone durable remissions. J Clin Oncol 4:160, 1986.

20. Sanger WG, Amnitage JO, Bridge J, Weisenburger DD, Fordyce R, Purtilo DT. Initial and subsequent cytogenetic studies in malignant lymphoma. Cancer 140:3014, 1987.

21. Hamden DG, Klinger HP, eds ISCN (1985). An intemational system for human cytogenetic nomenclature. Basel. Karger, 1985.

22. Erikson J, Williams DL, Finan J, Nowell PC, Croce CM. Locus of the a-chain of the T-cell receptor is split by chromosome translocation in T-cell leukemia. Science 229:784, 1985. 
23. Williams DL, Look $A T$, Melvin SL, et al. New chromosomal translocations correlate with specific immunophenotypes of childhood acute lymphoblastic leukemia. Cell 36:101, 1984.

24. Lewis WH, Michaelopoulos EE, Williams DL, Minden MD, Mak TW. Breakpoints in the human T-cell antigen receptor a-chain locusin two $T$-cell leukemia patients with chromosomal translocations. Nature $317: 544,1985$.

25. Boehm T, Buluwela $L$, Williams D, White $L$, Rabbitts TH. A cluster of chromosome pl3 transiocations found via distinct D-D and D-D-J rearrangements of the human T-cell receptor d-chain gene. EMBO J 7:2011, 1988.

26. Champagne E, Takihara $Y$, Sagman $U$, et al. The T-cell receptor d-chain locus is distupted in the T-ALL associated $t(11 ; 14)(p 13 ; q 11)$ translocation. Blood 73:1672, 1989.

27. Boehm T, Baer $\mathbf{R}$, Lavenir I, et all. The mechanism of chromosomal translocations at 1(11;14) involving the $\mathrm{T}$-cell receptor Cd-locus on human chromosome $14 \mathrm{q} 11$ and a transcribed region of chromosome $11 \mathrm{p} 15$. EMBO J 7:385, 1988 .

28. Grieser H, Tkachuk D, Reis MD, Mak TW. Gene rearrangements and translocations in lymphoproliferative disease. Blood 73:1402, 1989.

29. Rabbitts TH, Lefranc MP, Stinson MA, et al. The chromosomal location of T-cell receptor genes and a $T$ cell rearranging gene: possible correlation with specific translocations in human $T$-cell leukemia. EMBO J 4:1461, 1985.

30. Barker PE, Ruddle FM, Royer HD, Acuto O, Reinherz EL. Chromosomal locations of human T-cell receptor gene Ti beta. Science 226:348, 1984.

31. Reynolds TC, Smith SD, Sklar J. Analysis of DNA surrounding the breakpoints of cluromosomal translocations involving the Beta $T$ cell receptor gene in human lymphoblastic neoplasms. Cell 50:107, 1987...

32. Kaneko $Y$, Frizzera $G$, Maseki N, et al. A novel translocation, $t(9 ; 17)(q 34 ; q 23)$, in aggressive childhood lymphoblastic lymphoma. Leukemia $2: 745,1988$.

33. Kidd DD, Gusella J. Report of the committee on the genetic constitution of chromosomes 3 and 4. Eight International Human Gene Mapping Workshop. Cytogenet Cell Genet 40:93, 1985.

34. Povey S, Morton NE, Sherman SL. Report of the committee on the genetic constitution of chromosomes 1 and 2. Eight Intemational Human Gene Mapping Workshop. Cytogenet Cell Genet 40:60, 1985.

35. Naylor $\mathbf{S}$, Lalouel J-M, Shaw DJ. Report of the committee on the genetic constitution of chromosomes 17, 18 and 19. Eight Intemational Human Gene Mapping Workshop. Cytoggenet Cell Genet $40: 214,1985$.

36. Heim S, Mitelman F. Oncogenes and cancer chromosome abnormalities. in Cancer Cytogenetics. eds Heim S, Mitelman P. New York. Alan R. Liss Inc. 1987, p 265.

37. Godde Salz E. Abberations of chromosome 3. A marker of T-cell lymphomas? I Genet Hum 31:39, 1983.

38. Fujita $K$, Fukuhara $S$, Nasu $K$, et al. Recurrent chromosome abnormalities in adult T-cell lymphomas of peripheral T-cell origin. Int J Cancer 37:517, 1986. 


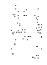

a.

7

a $\cdots$

:

s. 
CHAPTER 6

The prognostic significance of chromosomal abnormalities in patients with acute myeloid leukemia in a study comparing the efficacy of autologous and allogeneic bone marrow transplantation

Harry C. Schouten, Wim L.J. van Putten, Anne Hagemeyer, Geert H. Blijham, Pieter Sonneveld, Roel Willemze, Rosalyn Slater, Jan van de Lely, Leo F. Verdonck, Bob Löwenberg.

Submitted 


\section{Y Abstract}

In a prospective study designed to assess the efficacy of autologous bone marrow transplantation (ABMT) and allogeneic (allo) BMT in patients with acute myeloid leukemia (AML), we analyzed the prognostic significance of chromosomal abnormalities for obtaining complete remission $(C R)$, disease-free survival and survival. Patients with a normal karyotype were more likely to achieve a CR than patients with an abnormal chromosomal analysis $(p=0.02)$. There was no difference observed in survival from $C R$ between patients with or without chromosomal abnormalities, nor was there a difference if the analysis was restricted to subgroups of allogeneic or autologous BMT treated patients. Applying prognostic cytogenetic criteria as defined by Keating et al. $(7,11)$ no differences were observed between good and intermediate prognosis groups, although the poor prognosis group had a reduced $C R$ rate.

\section{$\mathrm{Y}$ Introduction}

Nonrandom chromosomal abnomalities have been observed in patients with AML. Some are associated with a particular subtype according to the FAB (1), for example $t(15 ; 17)$ with FAB subtype $\mathrm{M} 3$ (2) and inv(16) or del(16)(q22) with subtype M4 and abnormal eosinophils (3). Several studies have strongly suggested the prognostic significance of chromosomal abnormalities (4-15). In general, the presence of chromosomal abnormalities appears to be a poor prognostic factor, although certain specific chromosomal abnormalities may correlate with a higher CR rate or an advantage for survival $(7,9,11,14)$.

Factors of prognostic significance for outcome are related with the therapy given. It is possible that intensifying the therapy alters previously described correlations between prognostic factors and outcome. Intensification of the treatment of patients with AML with ABMT and alloBMT is increasingly used. Several reports demonstrate that BMT applied to patients in CR can decrease relapse rate and improve survival rates (16-18). We have studied 117 patients with AML who were treated in a prospective study (18) according to a protocol that included both $\mathrm{ABMT}$ and alloBMT. The prognostic significance of chromosomal abnormalities for $\mathrm{CR}$ rate, remission duration and survival was assessed in these patients. 
4 Patients and Methods

Between November 1984 and June 1987117 patients were treated in the Dutch multicenter prospective AML study (HOVON-1) (18). Previously untreated patients with apparently de nowo AML classified according to the criteria of the $\mathrm{FAB}$ (1) were entered, when they were between 15 and 60 years of age. In nine patients no cytogenetic analysis was done and in nine other patients inadequate material for the cytogenetic study was obtained after the start of the chemotherapy. These 18 patients were excluded.

Standard cytogenetic techniques were used including direct preparations $(n=37), 24$ or 48 hour cultures ( $n=71)$ and banding techniques (in all patients). The results of the four laboratories participating in this study were accepted as final. Of the 99 patients with a chromosomal study at diagnosis, the cells from 48 patients displayed only normal metaphases (NN), in 45 patients abnormal karyotypes were observed (in 16 patients only abnormal karyotypes (AA), in 29 patients there was an admixture of normal cells (AN)) and, finally, in six patients the results were inconclusive (IC) (no mitoses or only one abnormal cell). The specific abnormalities observed and their frequencies are listed in Table I.

The results of the complete HOVON-1 study have been reported elsewhere (18). Briefly, of the 99 patients involved in the present analysis $75(75 \%)$ reached a CR. Eighteen patients of those entering CR (24\%) had an HLA identical sibling and were treated with high dose cyclophosphamide, TBI and alloBMT. Twenty-seven of the patients achieving a CR $(36 \%)$ did not have an HLA identical sibling donor and received ABMT following high dose cyclophosphamide

Table I. Cytogenetic Abnormalities in 45 of 99 Patients with Acute Myeloid Leukemia.

\begin{tabular}{lr}
\hline & Number \\
\hline Specific translocations/abnormalities & 16 \\
$t(8 ; 21)(q 22 ; q 22)$ & 8 \\
Inv(16) or del(16)(q22) & 4 \\
$t(15 ; 17)(q 22 ; q 12)$ & 2 \\
$t(9 ; 1)(p 22 ; q 23)$ & 1 \\
$t(9 ; 22)(q 34 ; q 11)$ & 1 \\
$45, X_{i}-Y(M a l e)$ & 5 \\
Trisomy 8 & 6 \\
Hyperdiploid other & 20 \\
Monosomy 7 & 5 \\
Monosomy 5 & 4 \\
7q- & 3 \\
Hypodiploid other & 9
\end{tabular}


Table II. Distribution of Patients According to FAB Type at Diagnosis and Outcome of Chromosomal Analysis.

\begin{tabular}{|c|c|c|c|c|c|}
\hline & \multicolumn{5}{|c|}{ Karyotype of AML Cells (1) } \\
\hline $\begin{array}{l}\text { Patients ( } n \text { ) } \\
\text { age (yrs) } \pm S D \\
\text { mallenfemale }\end{array}$ & $\begin{array}{l}48 \\
42 \pm 12 \\
25 / 23\end{array}$ & $\begin{array}{l}29 \\
40 \div 14 \\
19 / 10\end{array}$ & $\begin{array}{l}16 \\
40 \pm 11 \\
12 / 4\end{array}$ & $\begin{array}{l}6 \\
38 \pm 14 \\
4 / 2\end{array}$ & $\begin{array}{l}99 \\
41 \pm 12 \\
60 / 39\end{array}$ \\
\hline \multicolumn{6}{|l|}{ FAB type } \\
\hline$M \| 1(n)$ & 9 & 4 & 0 & 0 & 13 \\
\hline $\mathrm{M} 2$ & 20 & 12 & 8 & 2 & 42 \\
\hline Mo & 3 & 1 & 1 & 0 & 5 \\
\hline M4 & 8 & 5 & 4 & 1 & 18 \\
\hline M5 & 6 & 6 & 2 & 2 & 16 \\
\hline M6 & 1 & 0 & 0 & 1 & 2 \\
\hline unctassified & 1 & 1 & 1 & 0 & 3 \\
\hline
\end{tabular}

(1) NN: normal karyotypes only; AA: abnormal karyotypes only; AN: normall and abnormal kanyotypes (2) n: number

and TBI. Twenty-five patients were not transplanted for various reasons mainly due to early relapse, refusal or early death. The five patients with an inconclusive chromosome analysis who reached a CR were not included in the analysis for survival after BMT. Patient characteristics and diagnosis are summarized in Table II. The follow-up of patients entered in this study is $25-58$ months (median 45 months). Data were analyzed as of September 1, 1989.

Table III. Response to Therapy of the Various Cytogenetic Groups.

\begin{tabular}{llll}
\hline Group & Patients $(\mathrm{n})$ & CR $(\%)$ & Median Survival \\
\hline Normal & 48 & $41(85)^{*}$ & 15.6 months \\
Abnormal & 45 & $29(64)^{*}$ & 15.5 months \\
& AA & 16 & $10(63) 13.6$ months \\
Inconclusive analysis & AN & 29 & $19(66) 15.8$ months \\
$:: 0=0.02$ & 6 & $5(83)$ & 7.4 months \\
& & & \\
\hline
\end{tabular}

\section{Study Design}

Because the groups of patients with specific chromosomal abnormalities were relatively small, the patients were grouped in NN, AN or AA (19). Survival and relapse-free survival probabilities were calculated according to the actuarial 
method of Kaplan and Meier (20). The log rank test was used to compare the groups of patients with respect to achieving CR and survivall (21).

AML patients can be classified into three prognostic groups based on the results of cytogenetic studies as reported by Keating et al. $(7,11)$. For remission induction patients with a $t(8 ; 21)$ or an inv(16) have a favorable prognosis, patients with a normal karyotype, $45, X,-Y$ or a $t(15 ; 17)$ have an intermediate prognosis and all other patients, including IC, have a poor prognosis. However, with respect to remission duration, $t(15 ; 17)$ or inv(16) anomalies represent the good prognostic cases, the normal, $t(8 ; 21)$ or $45, X,-Y$ karyotypes were of intermediate prognosis and all other cytogenetic conditions, including IC, were of poor prognosis. Because these prognostic cytogenetic indices have been confirmed in a prospective study (11), we analyzed the present data using these criteria.

\section{Y Results}

Of the 48 patients with a normal cytogenetic study $41(85 \%)$ reached CR (Table III). Of the 45 patients with an abnormal karyotype $29(64 \%)$ entered $\mathrm{CR}$. This difference is significant $(\mathrm{p}=0.02)$. No difference in $\mathrm{CR}$ rate was observed between AA and AN (CR rates of $66 \%$ and $63 \%$ respectively). Five out of six patients in the IC group reached a CR.

Table IV: Outcome after Bone Marrow Transplantation Related to the Results of Cytogenetic Analysis at Diagnosis.

\begin{tabular}{|c|c|c|c|}
\hline & & $\begin{array}{l}3 \text { Years Overall } \\
\text { Survival from } \mathrm{CR}\end{array}$ & $\begin{array}{l}3 \text { Years Disease } \\
\text { Free Survival }\end{array}$ \\
\hline Allo BMT & $\underline{n}$ & & \\
\hline nomal & $\overline{11}$ & $64 \%$ & $55 \%$ \\
\hline abnormal & 7 & $57 \%$ & $57 \%$ \\
\hline all & 18 & $63 \%$ & $57 \%$ \\
\hline \multicolumn{4}{|l|}{ Auto BMT } \\
\hline nomal & 16 & $36 \%$ & $37 \%$ \\
\hline abnormal & 11 & $36 \%$ & $36 \%$ \\
\hline all & 27 & $37 \%$ & $37 \%$ \\
\hline \multicolumn{4}{|l|}{ No BMT } \\
\hline nomal & 14 & $14 \%$ & $0 \%$ \\
\hline abnormal & 11 & $27 \%$ & $9 \%$ \\
\hline all & 25 & $19 \%$ & $4 \%$ \\
\hline
\end{tabular}


There was no difference in median survival between $A A, A N$ and $N N$ groups. Analysis of the duration of the remission or survival from CR did not disclose significant differences between $\mathrm{NN}, \mathrm{AN}$ or AA cases (figure). The same survival pattern was observed if the analysis was restricted to the subgroups of alloBMT and ABMT treated patients (Table IV).

Based on the prognostic cytogenetic criteria defined above $(7,11)$ we found no difference between the good prognosis and intermediate prognosis group as regards probability of $\mathrm{CR}$ (Table $\mathrm{V}$ ) but the poor prognosis group had a significantly reduced $C R$ rate $(P=0.0002)$. The remission duration, among the three prognostic karyotype groups did not differ at a median time of follow-up of 45 months (Table V).

\section{Discussion}

We have studied the prognostic significance of chromosomal abnormalities in patients with AML treated according to a protocol that was initiated to assess the value of alloBMT and ABMT. The results of the chromosomal analysis at diagnosis correlated with the probability of achieving a CR. No correlation was evident between the results of cytogenetic analysis and duration of $\mathrm{CR}$, disease-free survival, or survival. Consequently, there was no difference in outcome after BMT between patients with or without chromosomal abnormalities.

Our observations confirm previous studies $(4,10)$ which also reported a higher CR-rate for patients with normal karyotypes. However, our results are in contrast with studies where patients with normal chromosomes had an intermediate prognosis for $\mathrm{CR}$ rate $(7,11)$ or which did not show any difference between $\mathrm{NN}$, AN or AA (12). In several studies, patients with specific abnormalities such as $\mathrm{t}(8 ; 21)(4,11,12)$ or inv(16) $(4,11)$ had a comparatively favorable prognosis for achieving $\mathrm{CR}$.

We did not observe any correlation between results of chromosomal analysis and response duration or survival, which is in agreement with the findings of Weh et al (12). In contrast, correlations between a normal karyotype and better $(4,10,14,15)$ or intermediate (11) survival have been observed by others. Several specific abnormalities have also been correlated with increased survival such as del $16 \mathrm{q} 22$ or inv(16) $(7,9,11,14)$, a $t(8 ; 21)(9,12,14)$, or a $t(15 ; 17)(7,9,11,14)$. However, a $t(8 ; 21)$ or $45, \mathrm{XY}$-Y has been related to an intermediate prognosis in some studies $(7,11) . A+8$ and an abnormal 5 or 7 have been associated with a poor prognosis in other reports (14), but these abnormalities were more likely to occur in the elderly (9). These correlations between specific chromosomal abnormalities and survival were not observed in the present study, nor in the report of the Sixth International Workshop (15). The number of patients studied 


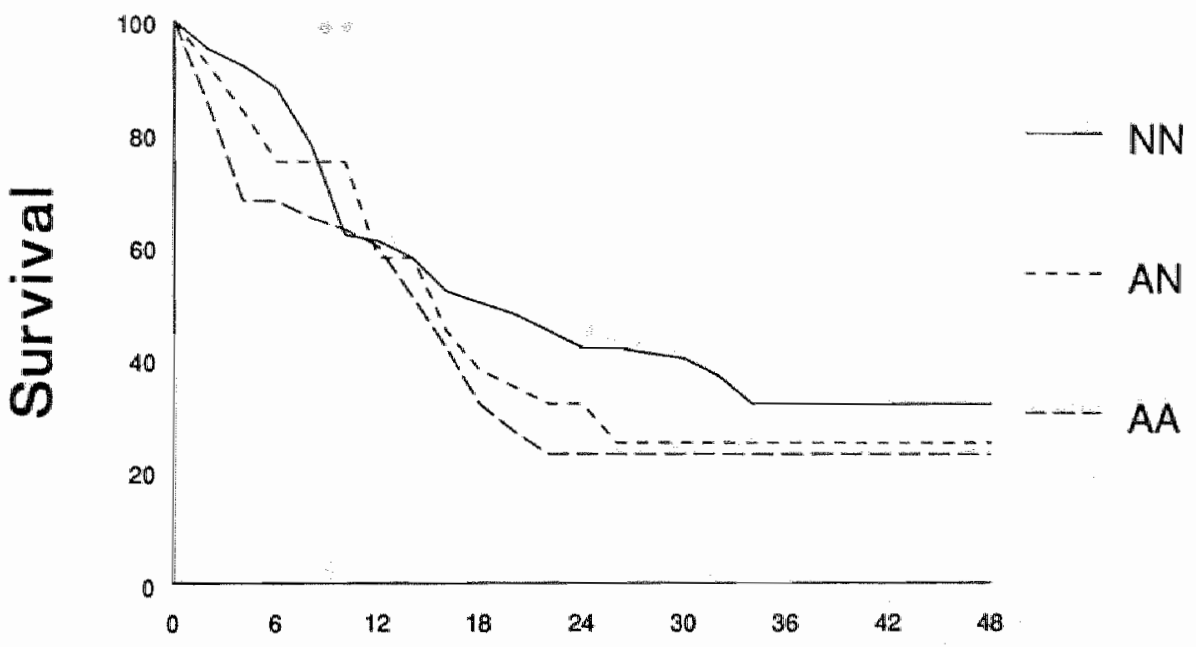

Months

Figure. Survival from Complete Remission by karyotype. NN: normal karyotype, AN: mixture of normal and abnormal cells, AA: abnormal karyotypes only.

may have been too small to detect differences. In addition, factors such as age, the inclusion of patients with a preleukemic phase, the distribution of patients over the FAB classification and the cytogenetic techniques used, may explain some of the reported discordant findings.

The absence in this study of a correlation between chromosomal studies and clinical outcome after CR must be interpreted in terms of the factors that might influence outcome in the post-CR treatment group. It is unlikely that cytogenetic abnormalities play a major role in determining the outcome after alloBMT because this outcome is mainly determined by the treatment related toxicity in addition to relapse. However, the outcome of patients treated with ABMT is largely dependent on disease characteristics. In these patients the presence or absence of chromosomal abnormalities did not show a significant correlation with outcome, suggesting a similar efficacy of marrow transplantation in both patient groups. It is possible that this analysis is too general and that an evaluation of specific chromosomal abnormalities rather than the mere difference between normal and abnormal will be of prognostic importance. Unfortunately, 
Table $\mathrm{V}$. CR rates and remission duration according to prognostic cytogenetic factors.

\begin{tabular}{lll} 
Remission Induction & \multicolumn{2}{c}{ No patients CR (\%) } \\
Good Prognosis $^{1}$ & 12 & $10(83)^{6}$ \\
Invermediatc $^{2}$ & 51 & $44(86)^{6}$ \\
Poor Prognosis $^{3}$ & 36 & $21(58)^{6}$
\end{tabular}

Remission Duration No Relapse or death Median duration

\begin{tabular}{|c|c|c|c|}
\hline Good Prognosis ${ }^{4}$ & 6 & $5(83 \%)$ & 9.9 months \\
\hline Intermediate & 48 & $33(69 \%)$ & 10.4 months \\
\hline Poor Prognosis ${ }^{3}$ & 21 & $14(67 \%)$ & 11.7 months \\
\hline
\end{tabular}

Cytogenetic factors were defined according to Keating et al $(7,11)$

1): $t(8 ; 21)$ or inv(16)

2): normal or $45, X,-Y$ or $t(15 ; 17)$

3): all other

4): $t(15: 17)$ or inv(16)

5): normal or $\mathrm{t}(8 ; 21)$ or $45, \mathrm{X}, \mathrm{Y}$

6): $\mathrm{p}=0.0002$

due to the limited number of patients with specific abnormalities, this question could not be properly addressed.

In conclusion, the higher remission rates in cases with a normal karyotype or with the specific changes as inv(16), $\mathrm{t}(8 ; 21)$, $\mathrm{t}(15 ; 17)$ were confirmed. However, in a group of patients treated with high dose therapy and bone marrow transplantation, we were not able to detect a correlation between the presence or absence of abnormal karyotypes and post remission survival. Greater numbers of such homogeneously treated patients may be required to assess possible correlations between specific chromosomal abnormalities and outcome. 


\section{References}

I. Bennett JM, Catovsky D, Daniel MT, Flandrin G, Gailon DAG, Gralnick HR, Sultan C. Proposed revised criteria for the classification of acute myeloid leukemia. Ann Intern Med $103: 620,1985$.

2. Larson RA, Kondo $K$, Vardiman JW, Butler AE, Golomb HM, Rowley JD. Evidence for a 15;17 translocation in every patient with acute promyelocytic leukemia. Am J Med 76:827, 1984.

3. LeBeau MM, Larson RA, Bitter MA, Vardiman JW, Golomb HM, Rowley JD. Association of an inversion of chromosome 16 with abnormal marrow eosinophils in acute myelomonocytic leukemia. N Engl J Med 309:630, 1983.

4. Berger $R$, Bemheim A, Ochoa-Noguera ME, Daniel MT, Valensi F, Sigaux F, Flandrin $G$, Boiron M. Prognostic significance of chromosomal abnormalities in acute nonlymphocytic leukemia: a study of 343 patients. Cancer Genet Cytogenet 28:293, 1987.

5. Samuels BL, Larson RA, LeBeau MM, Daly KM, Bitter MA, Vardiman JW, Barker CM, Rowley JD, Golomb HM. Specific chromosomal abnormalities in acute nonlymphocytic leukemia correlate with dng susceptibility in vivo. Leukemia $2: 79,1988$.

6. Fourth International Workshop on Chromosomes in leukemia. Clinical significance of chromosomal abnormalities in acute nonlymphoblastic leukemia. Cancer Genet Cytogenet 11:332, 1984.

7. Keating MJ, Cork A, Broach Y, Smith T, Walters RS, McCredie KB, Trujillo J, Freineich EJ. Toward a clinically relevant cytogenetic classification of acute myelogenous leukemia. Leukemia Res 11:119, 1987.

8. Kantarjian HM, Keating MJ, Walters RS, Beran M, McLaughlin P, McCredie KB, Freireich EJ. The association of specific "favorable" cytogenetic abnormalities with secondary leukemia. Cancer 58:924, 1986 .

9. Yunis JJ, Lobell M, Amesen MA, Oken MM, Mayer MG, Rydell RE, Brunning RD. Refined chromosome study helps define prognostic subgroups in most patients with primary myelodysplastic syndrome and acute myelogenous leukemia. Br J Haematol 68:189, 1988.

10. Larson RA, LeBeau MM, Vardiman JW, Testa JR, Golomb HM, Rowley JD. The predictive value of initial cytogenetic studies in 148 adults with acute nonlymphocytic leukemia: a 12-year study (1970-1982). Cancer Genet Cytogenet. 10:219, 1983.

11. Keating MJ, Smith TL Kantarjian H, Cork A, Walters R, Trujillo JM, McCredie KB, Gehan EA, Freireich EJ. Cytogenetic pattem in acute myelogenous leukemia: a major reproducible determinant of outcome. Leukemia $2: 403,1988$.

12. Weh HJ, Kuse R, Hoffmann R, Seeger D, Sucin S, Kabisch H, Retter I, Hossfeld DK. Prognostic significance of chromosome analysis in the novo acute myeloid leukemia (AML). Bhut 56:19, 1988 .

13. Billstrom $R$, Nilsson $P G$, Mitelman $F$. Chromosomes, auer rods and prognosis in acute myeloid leukemia. Eur J Haematol 40:273, 1988.

14. Schiffer CA, Le EJ, Tomisyasu T, Wiemik PH, Testa JR. Prognostic impact of cytogenetic abnormalities in patients with de novo acute nonlymphocytic leukemia. Blood $73: 263,1989$.

15. Arthur DC, Berger R, Golomb HM, Swansbury GJ, Reeves BR, Alimena $G$, van den Berghe H,

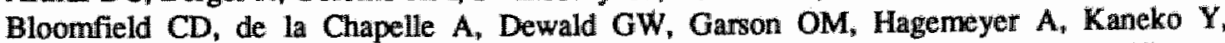
Miteiman F, Pierre RV, Ruutu $T$, Sakurai $M_{*}$ Lawler SD, Rowley JD. The clinical significance of karyotype in acute myelogenous leukemia. Cancer Genet Cytogenet 40:203, 1989.

16. Thomas ED, Clift RA, Buckner CD. Marrow transplantation for patients with acute non lymphoblastic leukaemia who achieve a first remission. Cancer Treat Rep 66:1463, 1982.

17. Burnett AK, Watkins $R$, Alcom M, Maharaj D, Singer CR, McKinnon $S$, McDonaid GA, Robertson AG. Transplantation of unpurged autologous bone marrow in acute myeloid leukemia in first remission. Lancet II: 1068, 1984. 
18. Lowenberg $B_{*}$ Verdonck LF, Dekker $A W$, Willemze $R_{\text {w }}$ Zwaan PE, de Planque $M$, Abels $J$, Sonneveld $P$, van der Lelie $J$, Goudsmit $R$, van Putten WLJ, Sizoo W. Hagenbeek A, de Gast GC. Autologous bone marrow transplantation in acute myeloid leukemia in first remission: results of a Dutch prospective study. I Clin Oncol 8:287, 1990.

19. Sakurai M, Sandberg A. Prognosis of acute myeloblastic leukemia: Chromosomal correlations. Blood 41:93, 1973.

20. Kaplan E, Meier 0 . Non-parametric estimation from incomplete observations. I Am Stat Assoc $53,457,1958$.

21. Peto R, Pike MC, Armitage P, Breslow NE, Cox DR, Howard SV, Mantel M, McPherson $\mathrm{K}_{\text {, }}$ Peto J, Smith $\mathrm{PG}$. Design and analysis of randomized clinical trials requiring prolonged observation of each patient. II. Analysis and Examples. Br J Cancer 35:1, 1977. 
CHAPTER 7

Epilogue 
The field of cancer cytogenetics is a rapidly developing research area. After the introduction of better cytogenetic analysis methods including banding techniques in the 1970's an overwhelming amount of data has become available. The majority of these chromosome studies have dealt with "diseases in suspension" such as acute myeloid leukemias (AML), chronic myeloid leukemias (CML) and, to a lesser extent, acute lymphoblastic leukemias (ALL). These data support the view that the leukemias are a clonal disease and that chromosomal changes appear to play a significant role in the pathogenesis of the acute leukemias. Also, the application of chromosomal analyses can be of help in detecting minimal residual disease. Many reports demonstrated the prognostic value of chromosomal abnormalities for response to therapy and survival. The natural course of CML is illustrative for another interesting phenomenon observed in human malignancies. A hallmark of this disease is the evolution after several years of an indolent course to the clinical picture of the blastic crisis. Repeated chromosomal analysis has resulted in the observation that this blastic crisis frequently is accompanied by new, additional chromosomal abnormalities.

Because of technical issues (described in chapter 1) data in solid tumors are more scarce. However, a substantial amount of data is now available for nonHodgkin's lymphoma (NHL) and, to a lesser extent, for Hodgkin's disease. These observations have supported the view that these diseases are clonal. In addition, several studies have reported correlations between specific chromosomal abnormalities, histologic subtype and clinical characteristics of the disease in NHL (see Chapters 3,4 and 5). At present, data in Hodgkin's disease are too limited to draw these conclusions (see Chapter 2). Also in NHL specific chromosomal abnormalities have been observed to correlate with response to therapy and survival (see Chapter 3). Preliminary data from follow-up chromosomal studies in NHL, like in CML, also suggest that there is a clonal evolution evidenced by the acquisition of new, additional chromosomal abnormalities. Conform the leukemias molecular biology has demonstrated that the chromosomal abnormalities observed in NHL are in several cases correlated with the localization of oncogenes and tumor suppressor genes.

This thesis, also, demonstrates that the picture in leukemia, NHL and Hodgkin's disease is very complex because of the multiplicity of chromosomal abnormalities observed and the heterogeneity of these diseases. Therefore, many patients have to be studied to detect significant correlations between chromosomal abnormalities and disease characteristics. The relatively low number of patients involved in our studies of Hodgkin's disease and T-cell NHL is, therefore, probably the most important reason for the fact that such correlations between disease characteristics and results from cytogenetic analyses were not detected in these diseases. 
In the future, studies as presented in this thesis should be repeated with a larger cohort of patients. The malignant cells of these patients should be analyzed at diagnosis not only using cytogenetic techniques but also using immuno-phenotyping and techniques derived from the molecular biology. Another important requirement is a homogeneous treatment for all patients. In addition, the patients should be studied not only at diagnosis but also at the time of relapse or disease progression. Data from this type of studies will help us to shed light on the pathogenesis and evolution of these malignant diseases. The results from these studies will also help us to define prognostic subgroups that will need an individualized treatment.

In contrast to NHL, in Hodgkin's disease the identity of the malignant cell is not clear. Debate continues whether the Reed-Stemberg cell is the malignant cell and whether this cell is from lymphoid or monocytoid/histiocytic origin or whether the normal appearing lymphocytes that are observed in the malignant tissue are part of the malignant clone. Also, in NHL it is not clear whether the malignant cells observed under the microscope are the clonogenic cells, and therefore the cells that should be destroyed, or that they are (terminally) differentiated malignant cells that have lost the ability to proliferate. A combination of the cytogenetic techniques and molecular biology might enable us to solve these questions.

Improvements in cytogenetic techniques, the use of these methods in a larger number of patients and the application of techniques from the molecular biology have provided us with the evidence Theodor Boveri lacked in the beginning of this century when he hypothesized that chromosome abnormalities are the cellular changes causing the transition from normal to malignant proliferation. Although this hypothesis has now been confirmed by many studies reporting high frequencies of chromosomal abnormalities in human malignancies, much knowledge has still to be acquired from and of cancer cytogenetics and molecular biology to solve questions dealing with the origin of neoplasms, the development of malignant transformation, the behaviour and evolution of the disease, the bodies' defence mechanisms and the importance of environmental influences.

In an era in which we are just beginning to make the first steps to get some insight in the subtlety of all processes involved in the delicate balance between controlled and uncontrolled proliferation, a new question comes up that also should be answered: why does neoplastic transformation not occur more frequently? 
\% a : :

s.

अ. $\therefore+\infty$

द. .

13:

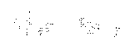

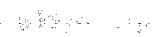




\section{CHAPTER 8}

\section{Summary}


保

Since the beginning of this century it was already hypothesized that chromosomal abnormalities were involved in the pathogenesis of malignant diseases. It took several decades before technical improvements of cytogenetic analysis allowed for the confirmation of this hypothesis. The first evidence came from "diseases in suspension" like the leukemias. In these diseases chromosomal abnormalities not only demonstrate the clonality of the disease, but they are also correlated with particular subtypes, suggesting their importance for the pathogenesis of these diseases. Because of many reasons, cytogenetic analyses of solid tumors were more difficult to perform.

Extensive analysis, not only using cytogenetic methods but also techniques from the molecular biology has now revealed the biological significance of the chromosomal abnormalities observed. In many cases translocations, deletions, additional or missing chromosomes or iso-chromosomes are correlated with particular genes located on the chromosomes involved. Today, not only oncogenes but also anti-oncogenes or tumor suppressor genes and tumor modulating genes can be discriminated. The oncogenes are the abnormal counterpart of the normal proto-oncogenes. These latter genes are involved in the regulation of normal proliferation and differentiation of the cell by playing a role in the production of growth factors and their receptors, the signal transduction from the receptor to the nucleus and in intra-nucleic functions. The tumor suppressor genes prevent by their presence uncontrolled proliferation. There is some evidence that the products of these genes are important for the regulation of DNA repair, the induction of differentiation and senescence, the control of proliferation and also angiogenesis. The function of tumor modulating genes is less clear, but they appear to be responsible for the interaction between host systems and tumor cells, the metabolism of carcinogens and resistance to invasive growth. In order to improve our knowledge of the pathogenesis of malignant hematological diseases and to assess the importance of chromosomal analysis of the malignant cells in these diseases for prognosis, an extensive analysis was done in patients with Hodgkin's disease, non-Hodgkin's lymphoma (NHL) and acute myeloid leukemia.

In Chapter 2 a group of 37 patients with Hodgkin's disease has been described. In $78 \%$ of these patients a successful chromosomal analysis could be performed. Of these patients $45 \%$ had chromosomal abnormalities. All patients had numerical abnormalities; $54 \%$ of these patients had structural changes in addition. However, because of this large variability no correlations could be observed between chromosomal abnormalities and biological characteristics of the disease.

The picture in NHL is somewhat different. In Chapter 3 the chromosomal abnormalities in 104 previously untreated patients have been described. Several abnormalities were correlated not only with disease characteristics but also with 
response to therapy and survival. The presence of particular abnormalities predicting a poor survival appeared to be independent prognostic factors in a multivariate analysis.

Chromosome 6 was frequently involved in the abnormalities observed in the patients with NHL. In a separate analysis of the 34 patients with NHL and an abnormal chromosome 6 (Chapter 4) some of these abnormalities were also found to be correlated with disease characteristics, response to therapy and survival. Especially the long arm of chromosome 6 was of importance.

The data on chromosomal abnormalities in T-cell NHL are very limited. In Chapter 520 patients with a T-cell NHL and a chromosomal analysis have been described. Several recurring abnormalities could be discriminated. Because of the variability of abnormalities and the limited number of patients no statistically significant correlations could be detected, although several associations between chromosomal abnormalities and histology and locallization of the disease were observed. Interestingly, the $\mathrm{T}$-cell receptor genes and genes correlated with $\mathrm{T}$ cell markers were relatively infrequently involved.

In AML several reports have already dealt with the importance of chromosomal abnormalities for the classification and response to therapy and survival. Because of the increasing importance of high-dose therapy followed by bone marrow transplantation, in Chapter 6 a study has been described analyzing the importance of chromosomal abnormalities for the outcome after the application of this treatment modality. Although the presence of a normal karyotype was important for achieving a complete remission (CR), no significant correlation could be detected for what happened after this $C R$, neither for survival nor for outcome after the transplant.

These studies clearly demonstrate the importance of chromosomal analyses in hematological malignancies. More studies, involving more patients treated homogeneously, should be performed. The results of these studies might help in unraveling the secrets of these malignant diseases, in detecting the location of genes important for the development or prevention of these diseases, in tailoring treatment regimens based on prognostic factors, in exploring new treatment regimens based on data from the molecular biology, and in making the detection of the malignant clonogenic cell, as for example in Hodgkin's disease, possible. We are just at the beginning of a very interesting era. 
\% a : :

s.

अ. $\therefore+\infty$

द. .

13:

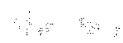

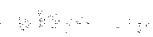


CHAPTER 9

\section{Samenvatting}


Sedert het begin van deze eeuw wordt reeds veronderstell, dat chromosomale afwijkingen van belang zijn voor de pathogenese van maligne ziekten. Het heeft echter nog een aantal decaden geduurd voordat door technische verbeteringen van de cytogenetische technieken deze hypothese bevestigd kon worden. De eerste aanwijzing was afkomstig van aandoeningen die van nature reeds in suspensie zijn, zoals leukemie. Bij deze ziekten bevestigde de aanwezigheid van chromosomale afwijkingen niet alleen de clonale aard ervan, maar bleken de chromosomale afwijkingen ook samen te hangen met bepaalde subtypes. Hierdoor is het zeer suggestief dat chromosomale afwijkingen een belangrijke rol spelen in de ontwikkeling van het pathologisch proces. Om een aantal redenen blijkt de cytogenetische analyse van solide tumoren ingewikkelder.

Uitgebreid onderzoek, niet allen met behulp van cytogenetica, maar ook met behulp van moleculair biologische technieken heeft inzicht gegeven in de biologische betekenis van deze chromosomale afwijkingen. In vele gevallen blijken translocaties, deleties, extra chromosomen, ontbrekende chromosomen of iso-chromosomen gecorreleerd te zijn met bepaalde genen die gelokaliseerd zijn op het aangedane chromosoom. Heden ten dage kunnen niet alleen oncogenen maar ook anti-oncogenen, of tumor suppressor genen, en tumor modulerende genen worden onderscheiden. Oncogenen zijn de abnormale tegenhanger van de normale proto-oncogenen. Deze laatste genen zijn betrokken bij de normale regulatie van proliferatie en differentiatie van de cel door een rol te spelen in de produktie van groeifactoren en groeifactor receptoren, in de signaal overbrenging van de receptor naar de celkern en intra-nucleaire functies. De tumor suppressor genen voorkomen door hun aanwezigheid onbeheerste groei. Er zijn aanwijzingen dat de produkten van deze genen van belang zijn voor de regulatie van DNA herstel, voor het aanzetten tot uitrijping en verouderingsprocesen, voor het onderdrukken van proliferatie en bloedvat nieuwvorming. De functie van de tumor modulerende genen is minder duidelijk. Ze lijken evenwel betrokken te zijn bij de interactie tussen tumorcel en gastheer, het metaboliseren van kanker verwekkende stoffen en de weerstand tegen invasieve groei. Om onze kennis van maligne haematologische ziekten te verbeteren en het belang van chromosomale analyse van maligne cellen bij deze ziekten voor de prognose vast te kunnen stellen, werd een uitgebreide analyse verricht van patiënten met de ziekte van Hodgkin, non-Hodgkin's lymfoom (NHL) en acute myeloide leukemie (AML).

In hoofdstuk 2 wordt een studie betreffende 37 patiënten met de ziekte van Hodgkin beschreven. In $78 \%$ van deze patiënten werd een adequate chromosomale analyse verkregen. Van deze patiënten had $45 \%$ chromosomale afwijkingen. Allen hadden numerieke afwijkingen, terwijl $54 \%$ ook nog structurele afwijkingen vertoonde. Echter vanwege de grote variatie in afwijkingen konden 
geen correlaties worden ontdekt tussen chromosomale afwijkingen en biologische kenmerken van de ziekte.

De situatie voor het NHL is enigszins verschillend. In hoofdstuk 3 worden de chromosomale afwijkingen van 104, tevoren niet behandelde, patiënten beschreven. Verschillende afwijkingen waren gecorreleerd aan niet alleen ziektekenmerken maar ook reactie op therapie en overleving. De aanwezigheid van afwijkingen met een voorspellende waarde voor een slechte overleving, bleek in een multivariant analyse een onafhankelijke prognostische betekenis te hebben.

Chromosoom 6 is regelmatig afwijkend in de patiënten met een NHL. In een afzonderlijke analyse van de 34 patiënten met NHL en een afwijkend chromosoom 6 (hoofdstuk 4) bleken verschillende afwijkingen met ziekte kenmerken, reactie op therapie en overleving gecorreleerd te zijn. Vooral afwijkingen van de lange arm van chromosoom 6 bleek van belang te zijn.

Weinig is bekend over chromosomale afwijkingen in T-cel NHL. In hoofdstuk 5 worden 20 patiënten met een T-cel NHL die een cytogenetisch onderzoek hebben ondergaan, beschreven. Verschillende, terugkerende afwijkingen konden worden onderscheiden. Vanwege de variatie in afwijkingen en het relatief kleine aantal patiënten konden geen statistisch significante correlaties worden gevonden. Wel konden enige relaties worden ontdekt die bij uitgebreider onderzoek toch van belang kunnen blijken te zijn. De genen die coderen voor de $\mathrm{T}$-cel receptor en voor $\mathrm{T}$-cel antigenen bleken relatief zelden bij de chromosomale afwijkingen betrokken te zijn.

Voor wat betreft AML, is in meerdere studies al het belang van chromosomale afwijkingen voor de classificatie en reactie op therapie en overleving aangetoond. In verband met het toenemende belang van hoge dosering chemoen/of radiotherapie gevolgd door beenmergtransplantatie wordt in hoofdstuk 6 een studie beschreven waarin het belang van chromosomale afwijkingen voor de resultaten van deze behandeling wordt bestudeerd. De aanwezigheid van een normaal karyotype bij diagnose bleek van belang voor de kans op het bereiken van een complete remissie. Chromosomale afwijkingen hadden evenwel geen enkele relatie met wat na deze remissie gebeurde, noch voor overleving noch voor resultaat van de beenmergtransplantatie.

Deze studies tonen duidelijk het belang aan van cytogenetische studies bij de haematologische maligniteiten. Meer onderzoek is nog noodzakelijk. De resultaten hiervan kunnen opheldering verschaffen over de geheimen van deze kwaadaardige aandoeningen. Ze kunnen behulpzaam zijn bij het opsporen van de lokalisaties van genen die voor de pathogenese van de ziekte van belang kunnen zijn. Op basis van deze gegevens kunnen nieuwe behandelingsprotocollen gebaseerd op prognostische factoren worden ontwikkeld. Ook moet het mogelijk worden nieuwe therapieèn te ontwikkelen gebaseerd op moleculair 
biologische kennis. Misschien kunnen de resultaten van deze studies ook behulpzaam zijn bij de identificatie van de maligne clonogene cel, zoals bijvoorbeeld bij de ziekte van Hodgkin. We staan nog maar aan het begin van een zeer interessant tijdperk. 


\section{Dankwoord}

$\mathrm{Na}$ het afronden van dit werkstuk is een woord van dank aan allen die hun steentje hebben bijgedragen op zijn plaats. Allereerst dient het Koningin Wilhelminafonds (tegenwoordig Nederlandse Kankerbestrijding) genoemd te worden. Immers door een klinisch fellowship kon de oversteek naar de Verenigde Staten gemaakt worden. Onder de onnavolgbare, inspirerende en stimulerende begeleiding van James $O$. Armitage MD (University of Nebraska Medical Center Omaha, NE, USA) werden de eerste schreden op het cytogenetisch onderzoekspad gezet, daarbij geholpen door de cytogeneticus Warren G. Sanger $\mathrm{PhD}$ en patholoog Dennis $\mathrm{D}$. Weisenburger $\mathrm{MD}$. Jim, Warren and Dennie, you deserve all the honor. Uiteraard moet ik de analisten vernoemen die me vertrouwd maakten met enkele cytogenetische technieken. Jene Pierson, Martin Bast and James Anderson $\mathrm{PhD}$ stonden mij bij in data management en statistiek. Vele meters papier líggen nog steeds in het raamkozijn van mijn voormalige kamer in Omaha. Lisa Stilahn typte menige pagina en begeleidde me bij tijdens mijn eerste stappen met WordPerfect. De AML studie kwam tot stand dankzij de belangrijke medewerking van de statisticus dr Wim van Putten (dr Daniel den Hoed kliniek), Prof dr Bob Löwenberg en de cytogenetici van de Academische Ziekenhuizen van Amsterdam, Leiden, Utrecht en Rotterdam.

Zoals bij vele onderzoeken worden pas aan het eind alle clinici, die de patiënten gegevens verstrekten, genoemd; zo ook nu. Zonder de Nebraska Lymphoma Study Group en het Nederlandse Samenwerkingsverband HOVON was dit onderzoek niet mogelijk geweest.

Niet in het minst moet nog vermeld worden de rol van Prof dr Geert Blijham. Hij was van oordeel dat al dit werk gebundeld kon worden tot een proefschrift en was een stimulans bij de uiteindelijke totstandkoming ervan. Mieke Haemers schreef vervolgens ook vele pagina's geduldig weg.

Last but not least dienen vermeld te worden de vier dames en éen heer die al het leed vanaf het begin hebben meegemaakt en nu hopen dat het voorbij is. 


\section{Curriculum vitae}

De auteur van dit proefschrift werd geboren op 11 februari 1953 te Roermond. Hij bezocht het Bisschoppelijk College te Roermond alwaar in 1972 het einddiploma Gymnasium B werd behaald. De medische studie werd gevolgd aan de Rijksuniversiteit te Utrecht en afgerond in 1980 met het Arts-examen.

Van 1980 tot 1982 was hij in het kader ven de A-2 opleiding werkzaam op de afdeling interne geneeskunde van het Bleuland ziekenhuis te Gouda (opleider: FH Veldhuijzen van Zanten). De A-5 opleiding werd vervolgens voltooid in het Zuiderziekenhuis te Rotterdam (opleider: Prof dr WH Birkenhäger) waarna hij in 1985 werd ingeschreven in het specialistenregister.

Van 1985 tot 1987 werden als junior-internist de eerste stappen in het haematologische veld gezet op de afdeling Haematologie van de dr Daniel den Hoed Kliniek te Rotterdam (hoofd: W Sizoo). Van 1987 tot 1989 was hij als klinisch fellow van het Koningin Wilhelmina fonds achtereenvolgens werkzaam op het celkweeklab van de dr Daniel den Hoed Kliniek te Rotterdam (hoofd: dr B Löwenberg), department of internal medicine, section of hematologyoncology, University of Nebraska Medical Center te Omaha, Nebraska, USA (section head: James O Armitage MD), alwaar het leeuwedeel van het onderzoek verricht werd, en het bloedtransfusie laboratorium Academisch Ziekenhuis Utrecht (hoofd: Prof dr GC de Gast). Sedert 1989 is hij als internist/staflid aangesteld bij de vakgroep interne geneeskunde (hoofd: Prof dr JA Flendrig), werkgroep haematologie-oncologie (hoofd: Prof dr GH Blijham) van het Academisch Ziekenhuis Maastricht. 